\title{
REVISTA
}

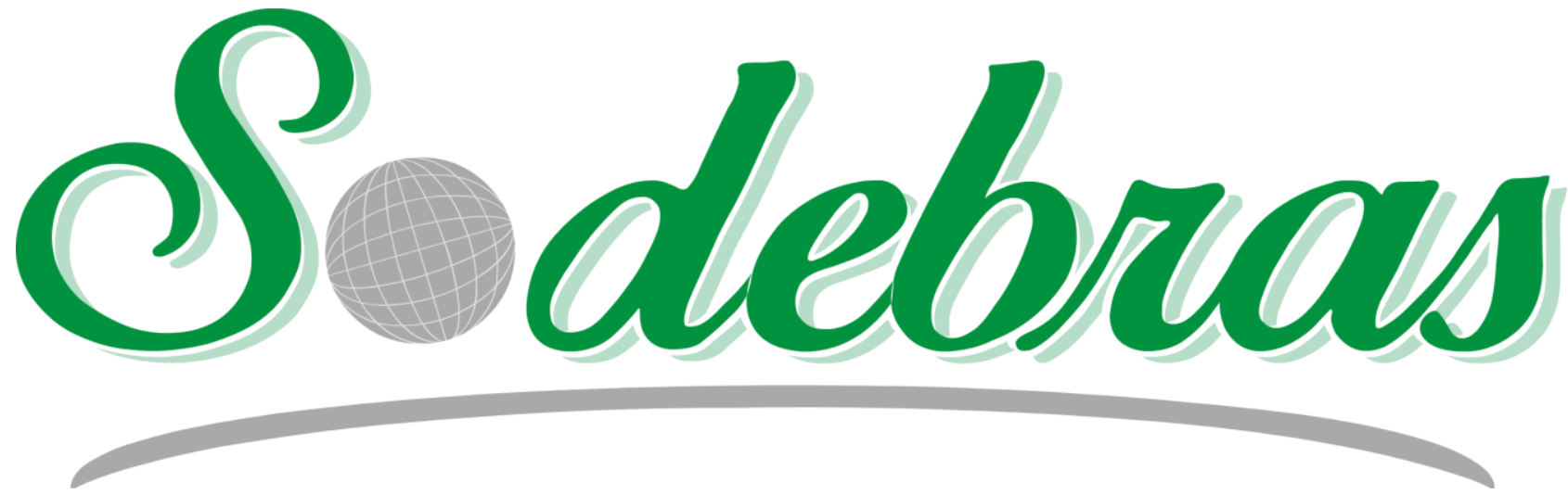

SOLUÇÕES PARA O DESENVOLVIMENTO DO PAÍS 


\title{
ARTIGOS PUBLICADOS
}

\author{
PUBLICAÇÃO MENSAL \\ Nesta edição
}

\section{DINHEIRO QUE VEM DO LIXO}

MONEY COMING FROM THE TRASH - Tiago Viana Fagundes; Marcus Antonius Da Costa Nunes

FATORES PREDISPONENTES AO USO DE DROGAS ILÍCITAS ENTRE ADOLESCENTES

FACTORS PREDICTING THE USE OF ILLICIT DRUGS BETWEEN ADOLESCENTS - Daniel Galeno Machado; Ana Paula Brito Rodrigues; Jordan Augusto Mota Aragão; Filadélfia Carvalho De Sena

GINÁSIO SANTO ANTÔNIO EM CARAVELAS: UM OLHAR SOBRE A EDUCAÇÃO NO EXTREMO SUL DA BAHIA - DÉCADA DE 1950

SAINT ANTHONY'S GYM IN CARAVELAS: A LOOK AT EDUCATION IN THE SOUTHERN SOUTH OF BAHIA - DECADE OF 1950 - Reginaldo Dos Santos Soares; Sônia Maria Da Costa Barreto

EDUCAÇÃO MATEMÁTICA: REPRESENTAÇÕES SOCIAIS DE ALUNOS DO $5^{\circ}$ ANO DAS SÉRIES INICIAIS DO ENSINO FUNDAMENTAL I

MATHEMATICAL EDUCATION: SOCIAL REPRESETATION OF STUDENTS IN THE 5 TH YEAR OF THE INITIAL GRADES OF ELEMENTARY SCHOOL I - Carlos Luis Pereira; Edson Rodrigues Dos Santos; Maria Do Carmo De Lima; Luiz Claudio Moro Aioffi; Rafael Roldi De Freitas Ribeiro; Ademir Hilário De Souza; Cristiano De Assis Silva

CONDIÇÕES DE BALNEABILIDADE NA ZONA COSTEIRA DO ESTADO DO PARÁ-BRASIL

CONDITIONS OF BATHING IN THE COASTAL ZONE OF THE STATE OF PARÁ-BRAZIL - Hebe Morganne Campos Ribeiro; Vítor Abner Borges Dutra; Danielle Nazaré Salgado Mamede Pantoja; Gleice Dos Santos

Cabral; Nailda Gomes Pantoja

USO DE EMBALAGENS ATIVAS PARA CONSERVAÇÃO E AUMENTO DA VIDA DE PRATELEIRA DE PRODUTOS ALIMENTÍCIOS: UMA BREVE REVISÃO

USE OF ACTIVE PACKAGING FOR THE CONSERVATION AND INCREASE OF SHELF LIFE OF FOOD PRODUCTS: A BRIEF REVIEW - langla Araújo De Melo Damasceno; Maykon Jhuly Martins De Paiva

INSTALAÇÕES ELÉTRICAS DE EQUIPAMENTOS ELETROMÉDICOS: AVALIAÇÃO DOS IMPACTOS DA QUALIDADE DE ENERGIA EM INSTITUIÇÕES DE SAÚDE

ELECTRICAL INSTALLATIONS OF MEDICAL ELECTRICAL EQUIPMENT: ASSESSMENT OF POWER QUALITY IMPACTS IN HEALTH INSTITUTIONS - Edenilso Tonielo; Ghendy Cardoso Junior ..

ANÁLISE NUMÉRICA DA INFLUÊNCIA DA VELOCIDADE DE SOLDA EM VASOS DE PRESSÃO CILÍNDRICOS

NUMERICAL ANALYSIS OF THE INFLUENCE OF WELDING SPEED IN CYLINDRICAL PRESSURE VESSELS - Fernanda Figueredo Santos; Jayann Ismar Lira Almeida 
PAPER SUBSTRATES TENSILE TESTING USING GRAPHITE PIEZORESISTORS FOR EXTRACTION OF THE EXPERIMENTAL YOUNG MODULE

ENSAIO DE TRAÇÃO EM SUBSTRATOS DE PAPEL USANDO PIEZORESISTORES DE GRAFITE PARA EXTRAÇÃO DO MÓDULO DE YOUNG EXPERIMENTAL - Débora Aline Kotz; Carlos Eduardo Andrades; Cristiane Sonego Rolim; Luiz Antonio Rasia; Antonio Carlos Valdiero 


\title{
Área: Interdisciplinar
}

\author{
9-18 DINHEIRO QUE VEM DO LIXO \\ MONEY COMING FROM THE TRASH \\ Tiago Viana Fagundes; Marcus Antonius Da Costa Nunes
}




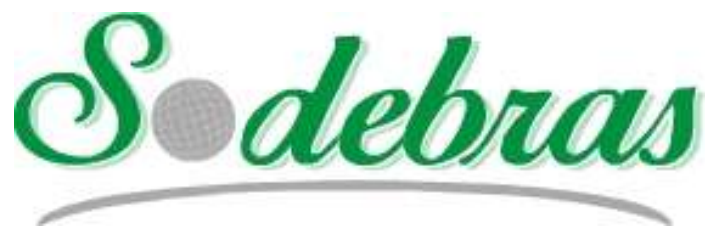

Revista SODEBRAS - Volume 14

$\mathrm{N}^{\circ} 158$ - FEVEREIRO/ 2019

\title{
DINHEIRO QUE VEM DO LIXO
}

\author{
MONEY COMING FROM THE TRASH
}

\author{
TIAGO VIANA FAGUNDES ${ }^{1}$; Dr. MARCUS ANTONIUS DA COSTA NUNES ${ }^{2}$ \\ 1; 2 - FACULDADE VALE DO CRICARÉ- SÃO MATEUS- ES \\ odinan2005@hotmail.com
}

\begin{abstract}
Resumo - Este trabalho foi executado com uma conscientização cidadã. Sabe-se que cada vez mais o meio ambiente em que vivemos torna-se difícil para a sobrevivência humana, devido ao uso demasiadamente distorcido da matéria prima. Uma das mazelas reveladas em relação às degradações ambientais é o lixo. De acordo com a demanda cresce também o consumismo desenfreado, o mesmo por sua vez, gerar toneladas de lixo. Nesse contexto, surge o interesse de pesquisar a Associação de Catadores de Reciclagem, criada em 2015, na cidade de Água Doce do Norte, ES. Portanto, o processo utilizado foi à pesquisa bibliográfica seguida de um estudo de campo. Revelou-se que a conscientização é cada vez mais imprescindível no convívio social, somente com esse método a população poderá consumir em harmonia com a natureza.
\end{abstract}

\section{Palavras-chave: Lixo. Convívio Social. Reciclagem.}

Abstract - This work was carried out with citizen awareness. It is known that more and more the environment in which we live becomes difficult for the human survival, due to the too skewed use of the raw material. One of the hazards revealed in relation to environmental degradation is rubbish. According to the demand also grows unbridled consumerism, the same turn, generate tons of garbage. In this context, it is interesting to research the Association of Recyclers, created in 2015, in the city of Água Doce do Norte, ES. Therefore, the process used was the bibliographic research followed by a field study. It has been revealed that awareness is increasingly essential in social life, only with this method can the population consume in harmony with nature.

Keywords: Garbage. Social Life. Recycling.

\section{INTRODUÇÃO}

Um dos grandes problemas da nossa sociedade é o lixo, ele é consequência daquilo que consumimos. Segundo dados ABRELPE (A Associação Brasileira de Empresas de Limpeza Pública e Resíduos Especiais), em 2012 apenas no Brasil foram produzidas 64 milhões de toneladas de resíduos sólidos, sendo que 24 milhões foram descartadas de forma errada. Hábitos sociais consequentes de um sistema capitalista incontrolável. Diante desse conhecimento, a cidade de Água Doce do Norte- ES organizou uma associação de catadores de resíduos sólidos, com uma visão de contribuir mesmo de forma modesta em comparação a grandes projetos, mais de forma grandiosa quando pensar consumir faz parte de uma educação ambiental. E para esse acontecimento cabe um processo de investimento no ensino, tendo como aliados os meios de comunicação, escola e reuniões com a comunidade.

\begin{abstract}
"Tomando-se como referência o fato de a maior parte da população brasileira viver em cidades, observa-se uma crescente degradação das condições de vida, refletindo uma crise ambiental (JACOBI, 2003, p.04)."
\end{abstract}

Analisando as palavras de Jacobi, a coleta seletiva do lixo só acontecerá com conscientização da população. Isto nos remete a uma necessária reflexão sobre os desafios para mudar as formas de pensar e agir em torno da questão ambiental numa perspectiva contemporânea. Sem um meio ambiente equilibrado não é possível ter uma boa qualidade de vida.

Assim, como em tantas outras cidades do Brasil, Água Doce do Norte, necessitava de uma propagação da educação ambiental. Não tinha coleta seletiva, e a população consumia sem retorno. Um morador da cidade organizou em 2015, juntamente com o apoio da comunidade, criar uma "Associação de Catadores de Reciclagem". Num caminho árduo e incerto o projeto cresceu e ganhou parcerias, as escolas do município, associação de moradores e prefeitura municipal. Palestras com orientação sobre a necessidade de retornar as embalagens foram ministradas nas escolas, rádios e placas com mensagens conscientizadora.

Antes da criação do projeto, a cidade gerava 190 toneladas de lixo, que eram destinados ao aterro sanitário, hoje se gera 90 toneladas, 100 toneladas deixaram de serem geradas graças ao incessante trabalho de conscientização em todo o município. Das 90 toneladas restantes, 10 são recicladas pela usina, gerando emprego e renda para 14 famílias. É um pequeno passo, porém, firme no processo do desenvolvimento. As famílias que trabalham na coleta seletiva viviam apenas do programa bolsa família do governo federal e de alguns trabalhos temporários. Hoje, segundo a secretaria do Meio Ambiente, conseguem uma renda de aproximadamente $\mathrm{R} \$ 800$ a $\mathrm{R} \$ 1.000,00$ por mês. A criação da associação fez uma conexão entre o consumo sustentável à geração de novos poços de trabalho no município. Dessa forma, as novas gerações adquiriram hábitos defensáveis sem prejuízo para a vida social.

O principal objetivo desse trabalho e conscientizar a população o real valor da iniciativa para um bem comum. Portanto, compreender que atividade de conscientização pode sanar parte dos problemas relacionados ao lixo das cidades, incluindo gerar recursos financeiros para a população. Porém, mais importante que recursos financeiros são preparar as pessoas para o convívio social. 


\section{MATERIAL E MÉTODOS}

Para elaborar o presente artigo foi utilizada metodologia como pesquisa de campo, conversas com o secretário do meio ambiente municipal; funcionários da associação de resíduos sólidos; prefeitura municipal; sites fidedignos referentes ao assunto e referências bibliográficas. Ideias sobre coletas seletivas já havia em Água Doce do Norte por parte de algumas pessoas. Elas coletavam materiais como; alumínio e ferro. Porém, papel, vidro e plástico não tinha um destino ecologicamente correto.

Os primeiros a terem iniciativa para coletar, disseram que foi um sonho realizado na cidade, pois o projeto veio concretizar um desejo antigo de consumir, retornar e reutilizar. Outras pessoas que não eram catadoras aderiram a causa na expectativa de ter sua renda mensal ampliada. $\mathrm{O}$ projeto Associação de Catadores de Reciclagem foi construído com amparo na Lei 12305/2010 (que instituiu a política nacional de resíduos sólidos) e a Lei 11.445/07 (que instituiu a política nacional do saneamento).

Para a construção do barracão onde seria instalada a usina, contamos principalmente com o apoio das pessoas da comunidade como pedreiros, carpinteiros, eletricistas, agricultores entre outros. O local escolhido foi um terreno doado pela prefeitura municipal, as margens da cidade. $\mathrm{O}$ projeto de conscientização contou com o apoio das escolas e da comunidade, houve propaganda na rádio da cidade, panfletagens nas ruas onde os próprios catadores explicavam sobre o seu trabalho e a importância de reciclar o lixo produzido. As escolas municipais inseriram no curriculum o trabalho de orientação da coleta seletiva. Sabe-se que a escola é de extrema importância para esse papel como podemos observar nas palavras de JACOBI (2003, p.5):

"Existe, portanto, a necessidade de incrementar os meios de informação e o acesso a eles, bem como papel indutivo do poder público nos conteúdos educacionais, como caminhos possíveis para alterar o quadro atual de degradação socioambiental. Tratase de promover o crescimento da consciência ambiental, expandindo a possibilidade de a população participar em nível mais alto no processo decisório, como uma forma de fortalecer sua corresponsabilidade na fiscalização e no controle dos agentes de degradação ambiental.’

O papel da sociedade é envolver pessoas em participação coletiva, formando novos costumes e adequando antigos. E o professor tem uma parcela fundamental em todas as mudanças sociais. Ainda segundo o documento do MEC (2000, p. 10):

"A proposta do MEC para a prática da EA na escola, implementada pela Coordenação Geral de Educação Ambiental, é a inserção da temática ambiental nos currículos, aliada à adoção de uma nova postura - de práticas e atitudes - de toda comunidade escolar, que pode ser exercitada em projetos de EA articulados com o projeto educativo da escola. E os professores são os principais agentes de implantação da EA na escola. Por isso mesmo, é necessário oferecer-lhes formação para desenvolvera capacidade de compreender, refletir e ensinar os temas relacionados ao meio ambiente."

Aos treze dias do mês de março do ano de 2015, na secretaria municipal do meio ambiente localizado na Vila Marinho no município de Água Doce do Norte - ES reuniram-se pessoas importantes nomes da cidade para deliberarem a formação da Associação de Catadores de Recicláveis de Água Doce do Norte. A partir dessa data - 13 de março de 2015 foram dados os primeiros passos para a construção do barracão, conforme a figura 1, e para um caminho ecologicamente correto, as pessoas começaram a tomar consciência de que reciclando o lixo ou reaproveitando alguns materiais já usados traria benefícios para todos, tendo assim uma cidade mais agradável e sustentável.

\section{Imagem 1 - Início da construção do barracão com o apoio de} moradores da comunidade

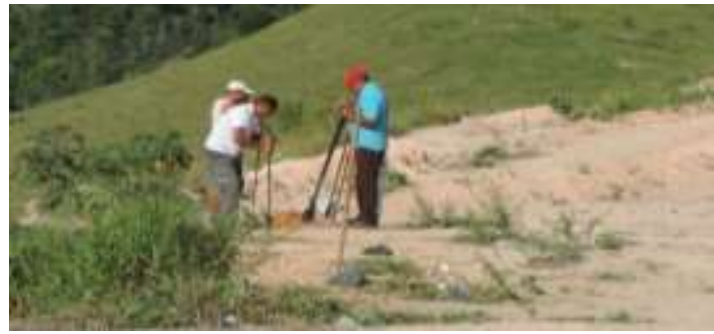

Fonte: Secretaria Municipal do Meio Ambiente.

\section{RESULTADOS}

Até o ano de 2015, 190 toneladas de lixo eram geradas em Água Doce do Norte, todo esse lixo era encaminhado para o aterro sanitário para a cidade de Aracruz - ES, através de um contrato com a empresa Ambitec, o lixo era transportado (imagem 2) por outra empresa, a RT, da cidade de São Gabriel da Palha - ES. Ambas geravam um custo para a prefeitura de aproximadamente de 48 a 50 mil reais por mês, dando um valor de aproximadamente 576 a 600 mil reais por ano.

No final de 2015, com a implantação da usina de reciclagem, das 190 toneladas de lixo, 100 foram coletadas pelos novos trabalhadores, gerando renda e beneficiando a limpeza da cidade. O trabalho foi concretizado, graças a conscientização nas diversas formas de orientação nas escolas e em toda a cidade com panfletagem, carro de som e palestras. A população se mobilizou de tal forma que a usina de reciclagem está funcionando com sucesso. Conforme imagem 2, 3 e 4 .

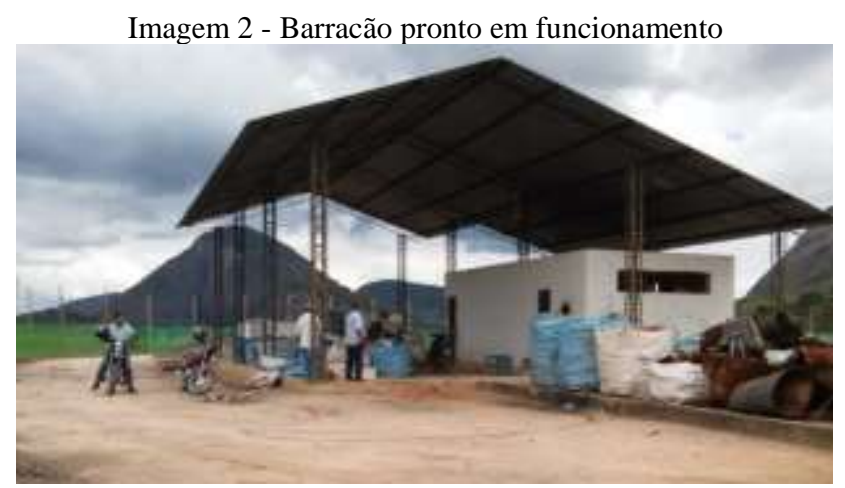

Fonte: Secretaria do Meio Ambiente. 


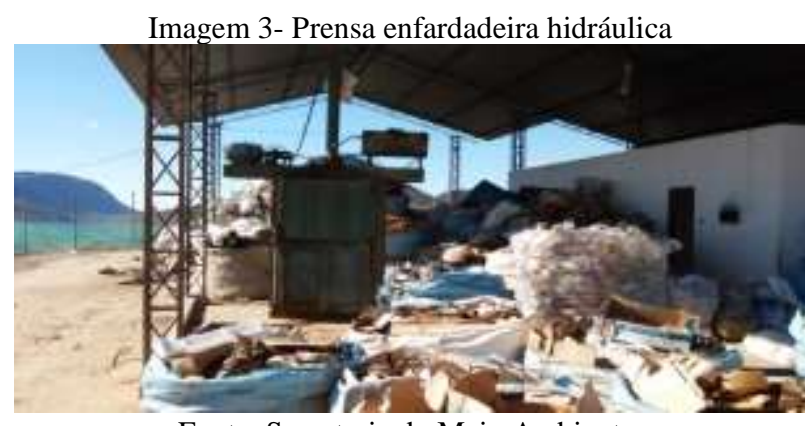

Fonte: Secretaria do Meio Ambiente.

A reciclagem gera emprego diretamente para 14 famílias (imagem 4), elas dividem entre si uma renda mensal de cinco mil reais por mês, porém, a prefeitura investe por mês 8.500 reais, esse recurso sai da economia da queda das toneladas de lixo que as pessoas deixaram de gerar, por mês cada catador, ao receberem seus salários, entre $\mathrm{R} \$ 600,00$ a $\mathrm{R} \$ 1.000,00$ reais, utilizam no comércio da própria cidade onde vivem, assim, movimentando a economia local. Portanto, o município já tem nova rotina na vida dos moradores, a coleta seletiva trouxe um olhar financeiro para as pessoas que compreenderam o processo de uma vida de consumismo moderado.

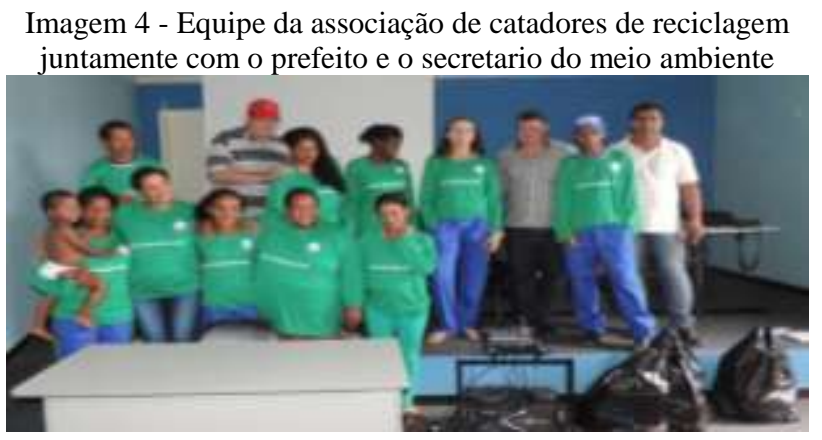

Fonte: secretaria do Meio Ambiente.

\section{DISCUSSÃO}

Conscientizar as pessoas a cuidar adequadamente de seu lixo não é tarefa fácil, no entanto, convencer 14 famílias de que é possível ganhar dinheiro através da reciclagem do lixo foi desafiador, porém, acreditou-se em um trabalho possível de realizar, mas hoje os resultados já fazem parte da estatística do município. Concretizando que lixo não é problema quando destinado ao local correto. Segundo a revista publicada pelo Ministério do Meio Ambiente - Lixo um grave problema no mundo moderno $(2002$, p. 4):

"A reciclagem é uma das alternativas de tratamento de resíduos sólidos mais vantajosos, tanto do ponto de vista ambiental como do social. Ela reduz o consumo de recursos naturais, poupa energia e água e ainda diminui o volume de lixo e a poluição."

Ainda há muito para fazer nos países subdesenvolvidos, a cerca da educação ambiental, mas quando se trata de Brasil, já conhecemos leis direcionadas ao meio ambiente como a Lei 12.305/07, a mesma proibi o acumulo dos resíduos em terrenos baldios e prevê o fim dos lixões através dos termos de Compromissos Ambientalistas (TCAS). Sinalizando assim, um novo tempo para adequação da educação ambiental no cotidiano da população brasileira. Segundo GONÇALVES (2003, p. 14).
"O lixo é um problema urgente, nosso objetivo é contribuir para a construção de políticas públicas na área que tenham como preocupação a educação ambiental, a conservação do meio ambiente, e a inclusão socioeconômica dos catadores de materiais recicláveis."

Sendo assim, o investimento em conscientização produz frutos ao longo tempo, com um trabalho continuo irá acarretar mudanças no comportamento social. A associação de coletores, já conta com um caminhão baú modelo D.40 da Chevrolet para ajudá-los no trabalho de coleta em todo o município. Também possui uma prensa enfardadeira hidráulica que já foi comprada em parceria com a prefeitura. E esperarão em breve receber uma doação da Agência de Desenvolvimento das Micro e Pequenas Empresas e do Empreendedorismo (ADERES), a empresa irá doar uma prensa nova. Sendo assim, aos poucos está sendo ampliada a usina de reciclagem, transformando o que era perdido em beneficio financeiro para as famílias associadas.

Imagem 5 - Carga completa de resíduos reciclados destinados para a venda

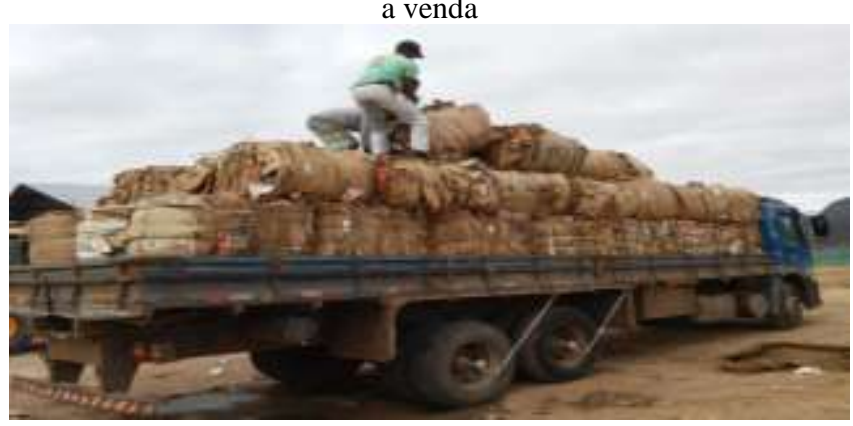

Fonte: Secretaria do Meio Ambiente.

Os membros e apoiadores dessa causa ambiental, já organizam uma iniciativa de criarem uma fábrica de vassouras pet, sendo que a matéria prima é coletada nas ruas e levada para ser transformada no galpão da empresa, fazendo planos de gerar mais emprego para a população da cidade. Também cursos de capacitação da mão de obra são ministrados para os integrantes, desde a criação da associação todo inicio de ano, participam de cursos de aprimoramento de manuseio com resíduos sólidos. No entanto, a participação no encontro Estadual dos catadores de Materiais Recicláveis do Espírito Santo, ’já faz parte da agenda dos funcionários.

Imagem 6 - Equipe da associação de catadores em frente ao palácio

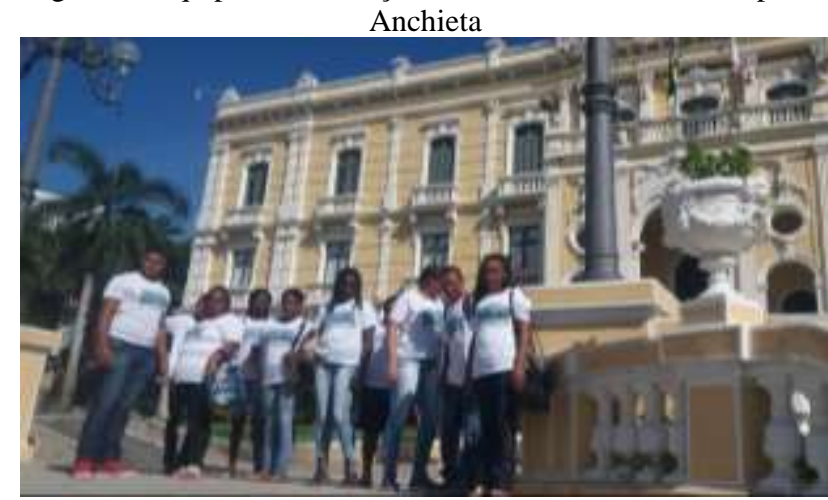

Fonte: Secretaria do Meio Ambiente. 
Imagem 7 - Entrega do certificado do curso de catadores

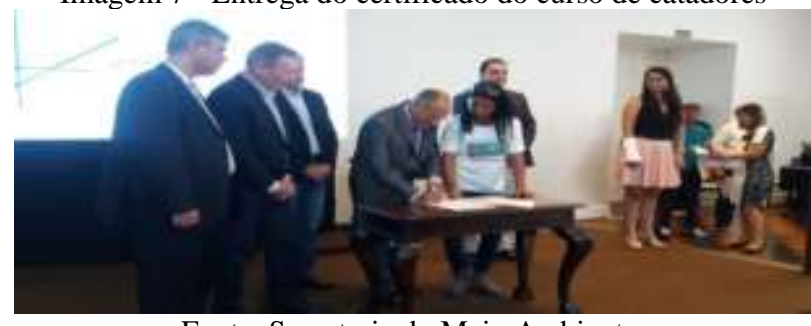

Fonte: Secretaria do Meio Ambiente.

Portanto, a articulação para manter os objetivos executados é essencial. O crescimento é gradativo, e ações serão executadas à medida que o aprendizado é concebido pelo grupo de trabalho. Sabe-se que, a grandiosidade das ações está no início da aplicação de uma tarefa. A percepção da necessidade de ajudar o meio ambiente foi o estepe determinante para o início de uma grande história a ser escrita por essa associação de reciclagem de produtos sólidos no município de água doce do norte - ES. Todo o processo será marcado com uma importante ajuda no equilíbrio socioambiental local.

\section{CONCLUSÃO}

Dessa forma, a rotina de uma cidade do interior do Estado de Espírito Santo mudou-se com o surgimento dessa associação de catadores de resíduos sólidos. Concluímos que o lixo bem coletado é fonte de renda e ambiente limpo e em equilíbrio. Por sua vez, o lixo quando não cuidado torna-se vilão da saúde pública, provocando doenças e acarretando gastos nos tratamentos em busca da cura. Diante do exposto, entendemos que, é imprescindível que todos se conscientizem em alternativas ecologicamente corretas, construindo assim, uma sociedade sustentável para nós e para as futuras gerações. O povo de Água Doce do Norte conscientizou-se da importante tarefa de conviver sem agredir o meio ambiente.

Acredito que os resultados da implantação da usina superaram as expectativas, porém há muito que se fazer até alcançar maturidade de uma empresa, planos e metas são traçados e executados para evitar o retrocesso ao longo do processo já percorrido. O objetivo inicial foi alcançado, principalmente graças ao trabalho de conscientização popular. A educação social sempre será a forma de amadurecer um povo de suas ações primarias. Hoje nas salas de aula, observa-se uma mudança de comportamento sobre a reciclagem do lixo domestico. As crianças são protagonistas na disseminação dessa ideia ecológica na rotina diária.

A cidade de Água Doce do Norte- ES, não possui mais lixão a céu aberto, visto que existem leis que os proíbem de fato. Portanto, o passo inovador é a nova rotina social todas baseada na Lei 12.305/07 (proíbe os resíduos sólidos a céu aberto).

Outra novidade são as áreas dos antigos pontos de descarte do lixo, os chamados lixões, já são áreas reflorestadas pela prefeitura e associação de catadores de resíduos sólidos. Sendo assim, os planos e metas traçados para o meio ambiente estão em execução. A disciplina da coleta seletiva virou rotina na cidade, quando os catadores passam nas ruas para coletar os resíduos sólidos destinados a reciclagem, os mesmos já estão separados do outro lixo. Comprovando a conscientização. Água Doce do Norte está longe de ser uma cidade perfeita em assuntos ambientais, mais trilha um caminho rumo a uma cidade sustentável, entretanto, só houve mudança com início de uma ação, que é lenta e gradual, mas o que realmente importa é iniciativa de projetos que organizem as pessoas no meio onde vivem.

\section{REFERÊNCIAS}

BBC. Galeria de lixão estrutural. Disponível em $<$ http://www.bbc.com/portuguese/noticias/2016/03/160310_ galeria_lixao_estrutural_pf $>$ Acesso em 15 de setembro de 2018.

Decreto-Lei no 9795: Dispõe sobre a Educação Ambiental e institui a Política Nacional de Educação Ambiental. Brasília: Diário Oficial da República Federativa do Brasil, 1999.

EXAME. Brasil pode economizar 8 bilhões se reciclar todo o lixo. Abril. Disponível em $<$ http://exame.abril.com.br/mundo/brasil-pode-economizarr-8-bilhoes-se-reciclar-todo-o-lixo-560090> Acesso em: 9 de outubro de 2018.

GONÇALVES, Pólita. A reciclagem integradora dos aspectos ambientais, sociais e econômicos. Ed. DP\&A, 2003.

JACOBI, Pedro. Educação ambiental, Cidadania e Sustentabilidade. USP, 2003.

MEC, 2000. Política Nacional De Educação Ambiental. Coordenação Geral de Educação Ambiental. Texto elaborado para Programa Salto para o Futuro - TV Escola.

\section{COPYRIGHT}

Direitos autorais: Os autores são os únicos responsáveis pelo material incluído no artigo.

Submetido em: $17 / 12 / 2018$ Aprovado em: 06/02/2019 


\section{Área: Ciências Humanas e Sociais}

\begin{tabular}{|c|c|}
\hline $7-7$ & $\begin{array}{l}\text { FATORES PREDISPONENTES AO USO DE } \text { DROGAS ILÍCITAS } \\
\text { ADOLESCENTES }\end{array}$ \\
\hline & $\begin{array}{l}\text { FACTORS PREDICTING THE USE OF ILLICIT DRUGS BETWEEN } \\
\text { ADOLESCENTS } \\
\text { Daniel Galeno Machado; Ana Paula Brito Rodrigues; Jordan Augusto Mota Aragão; } \\
\text { Filadélfia Carvalho De Sena }\end{array}$ \\
\hline $7-8$ & $\begin{array}{l}\text { GINÁSIO SANTO ANTÔNIO EM CARAVELAS : UM OLHAR SOBRE A } \\
\text { EDUCAÇÃO NO EXTREMO SUL DA BAHIA - DÉCADA DE } 1950 \\
\text { SAINT ANTHONY'S GYM IN CARAVELAS: A LOOK AT EDUCATION IN THE } \\
\text { SOUTHERN SOUTH OF BAHIA - DECADE OF } 1950 \\
\text { Reginaldo Dos Santos Soares; Sônia Maria Da Costa Barreto }\end{array}$ \\
\hline $7-8$ & $\begin{array}{l}\text { EDUCAÇÃO MATEMÁTICA: REPRESENTAÇÕES SOCIAIS DE ALUNOS DO } 5^{\circ} \\
\text { ANO DAS SÉRIES INICIAIS DO ENSINO FUNDAMENTAL I } \\
\text { MATHEMATICAL EDUCATION: SOCIAL REPRESETATION OF STUDENTS IN } \\
\text { THE } 5 \text { TH YEAR OF THE INITIAL GRADES OF ELEMENTARY SCHOOL I } \\
\text { Carlos Luis Pereira; Edson Rodrigues Dos Santos; Maria Do Carmo De Lima; Luiz } \\
\text { Claudio Moro Aioffi; Rafael Roldi De Freitas Ribeiro; Ademir Hilário De Souza; } \\
\text { Cristiano De Assis Silva }\end{array}$ \\
\hline
\end{tabular}




\author{
Revista SODEBRAS - Volume 14 \\ $\mathrm{N}^{\circ} 158$ - FEVEREIRO/ 2019
}

\title{
FATORES PREDISPONENTES AO USO DE DROGAS ILÍCITAS ENTRE ADOLESCENTES
}

\author{
FACTORS PREDICTING THE USE OF ILLICIT DRUGS BETWEEN \\ ADOLESCENTS
}

\author{
DANIEL GALENO MACHADO ${ }^{1}$; ANA PAULA BRITO RODRIGUES²;JORDAN AUGUSTO MOTA \\ ARAGÃO ${ }^{3}$; FILADÉLFIA CARVALHO DE SENA ${ }^{4}$ \\ 1,3 - UNIVERSIDADE ESTADUAL DO PIAUÍ; 2,4 - UNIVERSIDADE FEDERAL DO PIAUÍ \\ danielgalenoo@hotmail.com; anapaula_phb@hotmail.com; aragaojordan@hotmail.com; \\ filadelfia.psi@hotmail.com
}

\begin{abstract}
Resumo - A dependência química é cada vez mais um desafio para profissionais de saúde e, sobretudo, para a sociedade. Nas últimas décadas, a experimentação de drogas ilícitas tem aumentado precocemente em adolescentes, alcançando quadros de abuso e dependência. Este estudo teve por objetivo conhecer os fatores predisponentes ao uso de drogas ilícitas entre adolescentes. Tratase de um estudo de revisão de literatura do tipo integrativa. $O$ uso de drogas ilícitas pelos adolescentes em geral tem sido influenciado por questões de gênero, ambiente familiar conflituoso e faixa etária cada vez mais precoce no período da adolescência.
\end{abstract}

Palavras-chave: Drogas Ilícitas. Adolescente. Saúde Mental.

\begin{abstract}
Chemical dependency is increasingly a challenge for health professionals, and above all for society. In the last decades, drug experimentation has increased early in adolescents, with abuse and dependence. This study aimed to know the predisposing factors to the use of illicit drugs among adolescents. This is an integrative literature review. The use of illicit drugs by adolescents in general has been influenced by issues of gender, conflicting family environment and increasing age in adolescence
\end{abstract}

Keywords: Street Drugs. Adolescents. Mental Health.

\section{INTRODUÇÃO}

A saúde do adolescente tem sido um tema de interesse crescente não só entre pesquisadores, mas também entre os profissionais da área da saúde e nas agendas políticas mundiais. Isto se justifica pelo aumento expressivo do número de adolescentes no Brasil e no mundo, além das repercussões individuais biológicas e sociais que esta fase acarreta (BIASOLI-ALVES; FISCHMAN, 2004).

No âmbito da saúde mental, algumas situações clínicas são prioridades no atendimento ao adolescente, tais como a depressão, a ideação suicida, os transtornos de ansiedade, e, além destes, a identificação precoce do uso e abuso de drogas ilícitas.

A dependência química é cada vez mais um desafio para os profissionais de saúde e, sobretudo, para a sociedade. Nas últimas décadas, a experimentação de drogas ilícitas tem aumentado precocemente em adolescentes, alcançando quadros de abuso e dependência, apesar dos esforços preventivos dos setores públicos da área da saúde (JORGE et al., 2018).

O início do consumo de drogas ilícitas geralmente ocorre na adolescência tendo sido comum a frequência de uso nessa faixa etária. O uso de drogas ilícitas nessa fase pode acarretar uma série de consequências negativas em múltiplos domínios de vida, como prejuízos nas funções cognitivas e no desempenho de habilidades sociais, conflitos interpessoais, infração juvenil, entre outros (PASUCH; OLIVEIRA 2014).

Dentro desse contexto, o Ministério da Saúde e o Instituto Brasileiro de Geografia e Estatística constituíram parceria para a realização da primeira e segunda Pesquisa Nacional de Saúde do Escolar (PENSE) nos anos de 2009 e 2012, com o intuito de descrever as prevalências dos fatores de risco e proteção de doenças crônicas não transmissíveis em adolescentes, visando orientar políticas públicas de promoção da saúde nesse grupo etário.

A PENSE (2009) identificou que a experimentação de drogas ilícitas foi de 8,7\% para o conjunto dos alunos pesquisados nos Municípios das Capitais. Na PENSE (2012), a proporção para esse indicador, entre os adolescentes que frequentavam o $9^{\circ}$ ano do Ensino Fundamental em escolas dos Municípios das Capitais foi de 9,9\%, representando um ligeiro aumento em relação ao resultado observado há três anos (IBGE, 2009; IBGE, 2012).

Os resultados da PENSE (2012) também mostraram que, considerando exclusivamente os escolares que usaram drogas ilícitas pelo menos uma vez, 34,5\% utilizaram maconha e $6,4 \%$ consumiram crack nos 30 dias que antecederam a pesquisa. Em relação ao conjunto de escolares frequentando o $9^{\circ}$ ano do Ensino Fundamental, 0,5\% relataram o uso de crack no período (IBGE, 2012).

Quanto aos motivos, a maioria dos adolescentes faz uso de drogas ilícitas por motivos sociais, todavia, estudos apontam outros diferentes intuitos para o consumo dessas substâncias, como a busca pelo prazer, a diversão, a experimentação/curiosidade, a valorização social/pertencimento ao grupo, alívio do ócio e finalidade de relaxamento (VASTERS; PILLON, 2011).

O problema das drogas em adolescentes deve ser enfrentado em conjunto, sendo discutido por representantes da comunidade científica, das equipes de saúde, das esferas 
do governo, além de outros setores, de forma a evidenciar também as ações preventivas para evitar danos mais graves (MONTEIRO et al., 2012).

Portanto, considerando essa problemática de uso de drogas ilícitas entre adolescentes, o presente estudo teve como objetivo principal conhecer os fatores predisponentes ao uso de drogas ilícitas nesse público.

\section{PROCEDIMENTOS}

Para alcançar o objetivo proposto pelo presente estudo, optou-se pelo método da revisão de literatura do tipo integrativa, visto que ela permite fazer um apanhado da literatura de forma abrangente com o intuito de responder à um problema de pesquisa específico (SOARES et al. 2014).

A revisão integrativa é a mais ampla abordagem metodológica referente às revisões, permitindo a inclusão de estudos experimentais e não-experimentais para uma compreensão completa do fenômeno analisado. Combina também dados da literatura teórica e empírica, além de incorporar outros propósitos, tais como: definição de conceitos, revisão de teorias e evidências, e análise de problemas metodológicos de um tópico particular.

Essa ampla amostra, em conjunto com a multiplicidade de proposta, deve gerar um panorama consistente e compreensível de conceitos complexos, teorias ou problemas de saúde relevantes para a área que se utilizar desse método.

Sendo assim, o estudo abrangeu artigos publicados acerca dos fatores predisponentes ao uso de drogas ilícitas entre adolescentes. Na busca foram adotados os seguintes descritores controlados (encontrados nos Descritores em Saúde - Descs): Drogas Ilícitas, Adolescente, Saúde Mental. Quanto às bases de dados, os artigos foram pesquisados por meio do repositório da Bireme, onde foram escolhidas as bases de dados Literatura Internacional em Ciências da Saúde (MEDLINE), Literatura Latino-Americana e do Caribe em Ciências da Saúde (LILACS) e o Scientific Electronic Library Online (SciELO). Para a busca nas bases de dados foi utilizado o conector booleano "and" entre os descritores controlados para o refinamento da busca.

Os critérios de inclusão desta pesquisa foram artigos que versassem o objeto de estudo em questão de forma clara e precisa, textos redigidos em formato de artigo científico com pesquisa de campo, artigos completos e disponíveis, textos escritos na língua portuguesa/inglesa e o recorte temporal dos últimos 10 anos de literatura científica (20082018). Os critérios de exclusão foram publicações com ano inferior a 2008, artigos de estudo de caso e relato de experiência por não retratarem uma amostra representativa e artigos que não abordassem o tema escolhido pelo presente artigo.

\section{RESULTADOS}

A partir da análise dos resultados, emergiu-se três fatores predisponentes ao uso de drogas ilícitas entre adolescentes, nos quais, apareceu com maior frequência entre os artigos escolhidos pela presente revisão. Então, optou-se por discutir apenas esses fatores evidenciados pelos autores aqui escolhidos.

Assim, foi observado que o uso de drogas ilícitas pelos adolescentes em geral tem sido influenciado pelo grau de vulnerabilidade aos quais mais estão expostos tais como: questões de gênero, ambiente familiar conflituoso e faixa etária cada vez mais precoce no período da adolescência.
O gênero é uma variável sociodemográfica frequentemente associada ao uso de drogas entre adolescentes. Em geral, o consumo tende a ser mais frequente entre os adolescentes do sexo masculino, mas essa diferença vem diminuindo nos últimos anos. O uso de drogas ilícitas parece estar cada vez mais deixando de ser um comportamento essencialmente masculino em vários países, incluindo o Brasil, embora grande parte dos estudos com a população nessa faixa etária ainda aponte a tendência de o uso ser majoritariamente por adolescentes homens (MALBERGIER; CARDOSO; AMARAL, 2012).

Alguns estudos, como o de Raposo et al. (2017), ratifica o uso de drogas ilícitas com maior prevalência no sexo masculino em relação ao sexo feminino. Com relação aos estudos de Andrade et al. (2012), também há uma diferença de gênero identificada para o uso de drogas ilícitas, corroborando com os dados que mostram os adolescentes do sexo masculino com maior prevalência de uso que os adolescentes do sexo feminino. Esses resultados também são mostrados nos de estudos de Silveira et al. (2013), onde apontam 54,3\% dos adolescentes usuários de drogas ilícitas como sendo do sexo masculino e $45,7 \%$ do sexo feminino.

$\mathrm{O}$ maior uso de drogas pelo sexo masculino é um fator cultural e sociohistórico construído secularmente. As mulheres sempre tiveram seu papel voltado para o lar e os indivíduos do sexo masculino para o labor. Com isso, a representação do homem na sociedade fora aliada a liberdade de expressão e de uso de substâncias, perpetuando-se até os dias atuais.

A visão de empoderamento do sexo feminino se deu nas últimas décadas, corroborando em muitos estudos, o uso de drogas ilícitas concomitante por ambos os sexos. Mesmo sendo relatado ainda como a minoria, porém o uso de drogas ilícitas por esse público está se tornando cada vez mais evidente, o que se coloca como um ponto de alerta, pois as políticas públicas e os modos de assistência à saúde tendem a ser voltados para os homens, e, no entanto, devemos explorar a singularidade dos sujeitos independente da ideia de gênero.

Outro aspecto analisado no estudo de Backes et al. (2014) foi em relação à motivação do uso de drogas ilícitas entre os adolescentes, no qual foi verificado que as jovens do sexo feminino procuram as drogas como forma de compensação para os problemas de ordem afetiva e emocional, enquanto os do sexo masculino procuram-nas como forma de interação social, de socialização, de convívio entre amigos e como outras formas de lazer.

Quanto a essa questão da motivação para o uso de drogas ilícitas, os estudos têm mostrado que outra variável como o ambiente familiar exerce grande influência no início e na manutenção do consumo dessas drogas entre adolescentes.

Fatores como relacionamento ruim com os pais, ter membro da família que abusa e/ou é dependente de alguma substância, violência doméstica, desorganização familiar, viver apenas com um dos pais, pouca comunicação entre familiares e falta de suporte e monitoramento familiar tem sido constantemente associado ao uso de drogas nessa fase da vida (DALL'AGNOL; FASSA; FACCHINI, 2011).

Malbergier, Cardoso e Amaral (2012) corroboram com esses dados, apresentando em sua pesquisa a frequência de 3 a 5 vezes mais chances de ser usuário de drogas os adolescentes que tem algum membro da família que fez uso de maconha ou cocaína, de ter pais que usaram álcool a ponto de ter problemas, de ter algum membro da família que foi 
preso no mês anterior à entrevista, de discutir frequentemente com os pais, da família dificilmente fazer coisas juntos, dos pais não saberem onde eles estão ou o que estão fazendo e de sentir que os pais não se importam ou não cuidam deles.

A família, desde os tempos mais antigos, corresponde a um grupo social que exerce marcada influência sobre a vida das pessoas, sendo encarada como um grupo com uma organização complexa, inserido em um contexto social mais amplo com o qual mantém constante interação.

O grupo familiar tem um papel fundamental na constituição dos indivíduos, sendo importante na determinação e na organização da personalidade, além de influenciar significativamente no comportamento individual através das ações e medidas educativas tomadas no âmbito familiar.

Apesar do ambiente familiar conflituoso ter sido apontado como um dos fatores mais associados ao risco de uso de drogas ilícitas por adolescentes, a faixa etária mais precoce no período da adolescência tem se mostrado como outro fator predisponente ao uso dessas substâncias entre adolescentes.

De acordo com o estudo feito por Elicker et al. (2015) na região norte do país mostraram que os adolescentes que fizeram parte da pesquisa informaram usar drogas ilícitas, pela primeira vez, na faixa entre 13 e 15 anos de idade. Diante disso, esses dados se assemelham com um estudo desenvolvido no sul do Brasil por Vieira et al. (2008), no qual foi citado pelos autores, que houve também o primeiro contato com as drogas ilícitas, de forma mais prevalente aos 13 anos, mostrando, assim, que os adolescentes estão iniciando o consumo de drogas cada vez mais cedo.

Segundo estudiosos, o aumento significativo do uso de drogas ilícitas entre adolescentes e jovens e a precocidade dessa prática representam desafios para a saúde pública, em função da forte relação com outros agravos ambientais que comprometem a saúde e a vida, apontando alta vulnerabilidade destes grupos etários.

$\mathrm{Na}$ adolescência, fase da vida marcada por transformações psicossociais e busca da autonomia, os eventos negativos, tais como falta de suporte familiar e social, ambiente familiar conflituoso, entre outros fatores, aumentam a vulnerabilidade ao uso de drogas ilícitas e outros agravos associados ao consumo dessas substâncias. As ambivalências que gratificam e incomodam, podem gerar conflitos geracionais e psicossociais com a família e o ambiente

\section{CONCLUSÃO}

Diante disso, os dados dessa revisão nos permitem concluir que as drogas ilícitas são frequentemente experimentadas na adolescência e que determinados fatores predispõe o uso mais propício dessas drogas, tais como o gênero masculino, conflitos familiares e a faixa etária cada vez mais precoce no período da adolescência.

Essas substâncias, quando consumidas, trazem um grande prejuízo para o crescimento e desenvolvimento do adolescente, o que reforça a necessidade de um maior conhecimento acerca do fenômeno para o desenvolvimento de ações de prevenção e elaboração de políticas específicas dirigidas para esse grupo.

É importante salientar a importância de coletar, analisar e divulgar dados sobre uso de substâncias psicoativas entre adolescentes, o que é imprescindível para nortear as políticas de saúde pública e facilitar o planejamento, a implantação e a avaliação das intervenções para reduzir os encargos relacionados ao uso destas.

É dado como limitação do presente estudo a avaliação de artigos que utilizassem o padrão de uso de drogas ilícitas, o que não nos fez permitir inferências sobre o uso de bebidas alcoólicas e uso de tabaco, que também são substâncias as quais estimam grandes prevalências, sobretudo, na população jovem.

Portanto, é sugerido como objeto de investigação para outros estudos de revisão de literatura, a abrangência na discussão quanto ao uso tanto de drogas lícitas quanto ilícitas, para que seja possível suscitar uma reflexão mais ampla a respeito desse fenômeno que carece de medidas preventivas e específicas para o público juvenil.

\section{REFERÊNCIAS}

ANDRADE, Silvania Suely Caribé de Araújo et al. Relação entre violência física, consumo de álcool e outras drogas e bullying entre adolescentes escolares brasileiros. Cad. Saúde Pública, v.28, n.9, pp. 1725-1736, 2012.

BACKES, Dirce Stein et al. Indicadores de risco associados ao consumo de drogas ilícitas em escolares de uma comunidade do sul do Brasil. Ciênc. saúde coletiva, v.19, n.3, pp. 899-906, 2014.

BIASOLI-ALVES, Z. M.; FISCHMAN R. Crianças e adolescentes: construindo uma cultura da tolerância. São Paulo (SP): EDUSP, 2004.

DALL'AGNOL, M. M.; FASSA, A. C. G.; FACCHINI, L.A. Child and adolescent labor and smoking: a cross-sectional study in southern Brazil. Cad Saúde Pública, v.27, p.46-56, 2011.

ELICKER, Eliane et al . Uso de álcool, tabaco e outras drogas por adolescentes escolares de Porto Velho-RO, Brasil. Epidemiol. Serv. Saúde, Brasília , v. 24, n. 3, p. 399-410, Sept. 2015 .

Instituto Brasileiro de Geografia e Estatística. Pesquisa Nacional de Saúde do escolar (PeNSE) 2009. Rio de Janeiro, 2009.

Instituto Brasileiro de Geografia e Estatística. Pesquisa Nacional de Saúde do escolar (PeNSE) 2012. Rio de Janeiro, 2012.

JORGE, Kelly Oliva et al . Influência do grupo de pares e uso de drogas ilícitas entre adolescentes brasileiros: um estudo transversal. Cad. Saúde Pública, Rio de Janeiro, v. 34, n. 3, e00144316, 2018.

MALBERGIER, André; CARDOSO, Luciana Roberta Donola; AMARAL, Ricardo Abrantes do. Uso de substâncias na adolescência e problemas familiares. Cad. Saúde Pública, v.28, n.4, pp. 678-688, 2012.

MONTEIRO, Claudete Ferreira de Souza et al. Adolescentes e o uso de drogas ilícitas: um estudo transversal. Rev. enferm. UERJ, Rio de Janeiro, v.20, n.3, p.344-8, 2012.

PASUCH, C; OLIVEIRA, M. S. Levantamento sobre o uso de drogas por estudantes do ensino médio: Uma revisão 
sistemática. Cad. Ter. Ocup. UFSCar, São Carlos, v. 22, n. Suplemento Especial, p. 171-183, 2014.

RAPOSO, Jakelline Cipriano dos Santos et al . Uso de drogas ilícitas e bingedrinking entre estudantes adolescentes. Rev. Saúde Pública, São Paulo, v. 51, 83, 2017.

SILVEIRA, Helaine Silva et al. Efeitos das drogas lícitas e ilícitas na percepção de adolescentes: uma abordagem de enfermagem. Rev. enferm. UERJ, Rio de Janeiro, v. 21 (esp.2), p.748-53, 2013.

SOARES, Cassia Baldini et al . Revisão integrativa: conceitos e métodos utilizados na enfermagem. Rev. esc. enferm. USP, São Paulo, v. 48, n. 2, p. 335-345, Apr. 2014.

VASTERS, Gabriela Pereira; PILLON, Sandra Cristina. O uso de drogas por adolescentes e suas percepções sobre adesão e abandono de tratamento especializado. Rev. Latino-Am. Enfermagem, Ribeirão Preto, v.19, n.2, p. 317324, Apr. 2011.

VIEIRA, P.C et al. Uso de álcool, tabaco e outras drogas por adolescentes escolares em município do Sul do Brasil. Cad Saúde Pública, v.24, p.2487-98, 2008.

\section{COPYRIGHT}

Direitos autorais: Os autores são os únicos responsáveis pelo material incluído no artigo.

Submetido em: 06/12/2018 Aprovado em: 19/02/2019 


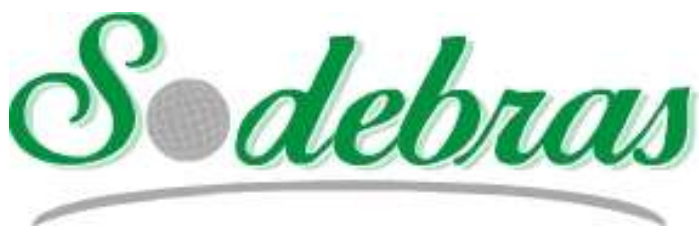

Revista SODEBRAS - Volume 14

$\mathrm{N}^{\circ} 158$ - FEVEREIRO/2019

\title{
GINÁSIO SANTO ANTÔNIO EM CARAVELAS : UM OLHAR SOBRE A EDUCAÇÃO NO EXTREMO SUL DA BAHIA - DÉCADA DE 1950
}

\section{SAINT ANTHONY’S GYM IN CARAVELAS: A LOOK AT EDUCATION IN THE SOUTHERN SOUTH OF BAHIA - DECADE OF 1950}

\author{
REGINALDO DOS SANTOS SOARES ${ }^{1}$; SÔNIA MARIA DA COSTA BARRETO² \\ 1 - MESTRANDO DO PROGRAMA DE PÓS-GRADUAÇÃO STRICTO SENSU - MESTRADO PROFISSIONAL \\ EM GESTÃO SOCIAL, EDUCAÇÃO E DESENVOLVIMENTO REGIONAL - FACULDADE VALE DO \\ CRICARÉ - FVC; 2 - PROF ${ }^{\text {a }}$ DRA. TITULAR DO MESTRADO PROFISSIONAL EM GESTÃO SOCIAL, \\ EDUCAÇÃO E DESENVOLVIMENTO REGIONAL - FACULDADE VALE DO CRICARÉ \\ rrsoares_ba@hotmail.com; soniamcb@terra.com.br
}

\begin{abstract}
Resumo - A presente pesquisa retrata a fundação e trajetória do Ginásio Santo Antônio em Caravelas, cidade situada no Estremo Sul da Bahia. O referido ginásio ainda hoje é considerado um marco cultural e institucional da cidade. A fim de nortear a nossa escrita optamos pela pesquisa bibliográfica, documental e a história oral, principalmente nos arquivos da instituição referida, de particulares e em entrevistas realizadas com pessoas locais. Para entender este processo, apresentamos a história da cidade de Caravelas $e$ a participação daqueles que atuaram nessa instituição de ensino na década de 1950. Também procuramos relatar o contexto da época, sobretudo no quesito educação.
\end{abstract}

Palavras-chave: Educação. Caravelas. Ginásio Santo Antônio.

Abstract - This gym is still considered a landmark of the city cultural and institutional. In order to guide our writing, we opted for the bibliographical research, documents and oral history, especially in the archives of the institution, of individuals and in interviews with local people. To understand this process, we present the history of the city of Caravels and the participation of those who worked in this educational institution in the Decade of 1950. We also look to report the context of the time, especially in terms of education.

Keywords: Education. Caravels. Gymnasium St. Antony.

\section{INTRODUÇÃO}

A história do Ginásio Santo Antônio é contada com muito orgulho pelos moradores de Caravelas, cidade bicentenária baiana, fundada no século XVI. Para investigar a sua história é necessário um mergulho na cultura local, nas festividades, na historicidade do povo que ainda mantém a lembrança da época do seu apogeu. A cidade de Caravelas passou por um período de decadência diminuindo a sua influência enquanto capital da microrregião e assim viu desaparecer importantes instituições, dentre elas, o Ginásio Santo Antônio.

${ }^{1}$ Os Colégios Polivalentes começaram a ser construídos no período da Ditadura Militar no Brasil, após a assinatura dos acordos MECUSAID, por meio dos quais foram disponibilizados recursos financeiros, oriundos dos Estados Unidos, destinados à educação brasileira.
A nossa intenção é a de apresentar a importância do Ginásio Santo Antônio e o contexto histórico, econômico, político e cultural da sociedade da época. A investigação leva em consideração o recorte temporal - década de 1950, embora o Ginásio legou incontestável importância para o desenvolvimento de uma elite escolar no período de 1950 a 1970. Consideramos também o andamento que o processo educacional tomou através dos tempos, para que possamos entender o ensino e o processo de construção cultural com a vinda do Colégio Polivalente de Caravela ${ }^{1}$, que dialeticamente influenciou os moldes sociais de formação do cidadão caravelense inspirado por paradigmas construídos e representados por tessituras políticas geradas e alimentadas no cenário educacional daquela época.

Ao nos debruçarmos sobre o passado em suas múltiplas relações com o presente, consideramos importante o saber histórico acadêmico, pois ele recorre a metodologias e procedimentos próprios da pesquisa em história. O desafio para o pesquisador torna-se maior, uma vez que terá que fazer o trabalho investigativo em forma de garimpo em busca do material pertinente ao seu objeto de pesquisa. Apesar das adversidades, a maior parte do material foi obtido por meio da construção de rede de relacionamento e conhecimento.

Os elementos basilares voltados para a história enquanto ciência e os princípios norteadores da sua escrita, apresentam interfaces que perpassam a trajetória da ciência historiográfica, como a história positivista e a nova história; a relação temporal do presente, passado e futuro; as mudanças e permanências; os espaços de memória e as memórias; a história como ciências e os diversos sentidos polissêmicos da história.

Desse modo, concordamos com Hobsbawn (2012, p.13), quando se refere ao passado:

A criação de tais escolas faz parte da reforma educacional já prevista pela Lei $\mathrm{n}^{\circ}$ 5.692/71, que reformulou os ensinos de $1^{\circ}$ e $2^{\circ}$ graus, tornando este último obrigatório e profissionalizante. 
"[...] A destruição do passado - ou melhor, dos mecanismos sociais que vinculam nossa experiência pessoal à das gerações passadas - é um dos fenômenos mais característicos e lúgubres do final do século $\mathrm{XX}$. Quase todos os jovens de hoje crescem numa espécie de presente contínuo, sem qualquer relação orgânica com o passado público da época em que vivem. Por isso os historiadores, cujo ofício é lembrar o que outros esquecem, tornam-se mais importantes que nunca no fim do segundo milênio. Por esse mesmo motivo, porém, eles têm de ser mais que simples cronistas, memorialistas e compiladores. Em 1989 todos os governos do mundo, e particularmente todos os ministérios do Exterior do mundo, ter-se-iam beneficiado de um seminário sobre os acordos de paz firmados após as duas guerras mundiais, que a maioria deles aparentemente havia esquecido [...]."

A visão de quem "procura saber" emana do historiador, isto é, daquele que busca identificar, compreender e explicar as atividades humanas. Segundo Michel De Certeau (1982), o historiador padece de uma frustração originária. O trabalho do historiador não é apenas técnico, pois não está restrito ao ambiente acadêmico e nem divorciado das tramas sociais e políticas que dão sentido a sociedade no tempo presente. Para tanto, esta pesquisa acessa de forma direta a memória conforme Oliveira (2013, p. 14).

"A memória histórica guarda várias narrativas através dos vários grupos sociais, instituições, classes. A história, como produção do conhecimento científico, compõe outras narrativas. Embasadas numa das visões que a sociedade guardou, muitas vezes, partindo dessa memória, grupos ou indivíduos compõem um conhecimento que vai de encontro a ela.

O profissional de história deve demonstrar essas ligações - do passado com o presente - e, embora não deva instituir numa como verdade única (o que entendemos por história tradicional é exatamente essa operação), deve ter clareza de que a memória influencia a história, a história influencia a memória."

As memórias são criadas e recriadas pelos autores que miram no horizonte da história da vida e das historicidades de municípios, vilas, bairros, monumentos, instituições, expressando os diversos sentimentos e recordações das pessoas que nestes locais vivenciaram as experiências, ou seja, há uma interação humana. Na produção da História Local figuram vários agentes que tem a função de garantir história/memória contemporânea. Pierre Nora (1993) ao refletir sobre os lugares de memória indica a importância de celebrar e vivenciar a memória nas datas, aniversários, atos fúnebres que vão se relembrando na memória. Deste modo, o olhar para a História Local apresenta os diversos lugares de memória, que dependendo do uso e da apropriação que a comunidade tem é significativa, pois na visão de Nora os "lugares de memória" podem ser identificados.

Nora (1993, p.21-22) considera que:

"São lugares, com efeito nos três sentidos da palavra material, simbólico e funcional, simultaneamente, somente em graus diversos. Mesmo um lugar de aparência puramente material, como um depósito de arquivos, só é lugar de memória se a imaginação o reveste de uma aura simbólica. Mesmo um lugar puramente funcional, como um manual de aula, um testamento, uma associação de antigos combatentes, só entra na categoria se for objeto de um ritual. Mesmo um minuto de silêncio, que parece o exemplo extremo de uma significação simbólica, é, ao mesmo tempo o recorte material de uma unidade temporal e serve, periodicamente, para uma chamada concentrada da lembrança. Os três coexistem sempre."

Nessa perspectiva, o historiador deve relatar o ocorrido entre as relações sociais de cada época destacando e elaborando valores que acabavam por determinar a posição do homem e/ou instituição e seu lugar na sociedade. Assim, não existe sociedade sem memória e esta, é constituída pelos vestígios deixados pelas gerações passadas.

\section{CIDADE DE CARAVELAS: EXTREMO SUL DA BAHIA}

A história de Caravelas é baseada em relatos de antigos moradores da cidade e região. De acordo com a narrativa do Professor de História aposentado, Francisco de Almeida Oliveira a cidade de Caravelas pode ser descrita como uma cidadezinha provinciana e que ainda cultua esses hábitos de interior porque qualquer novidade que vem para Caravelas, a sociedade tradicionalista começa a colocar entraves para perpetuar as suas primitivas características.

Historicamente o progresso foi manifestado principalmente pela produção de farinha e da pesca (Cancela, 2012). No final do século XIX houve um processo de imigração especialmente estrangeira na região para substituição da mão de obra escrava na agricultura, como os Italianos que se fixaram principalmente em Belmonte. Em 1882 começou a ser construída a Estrada de Ferro Bahia - Minas, pelo Governo da Bahia, partindo de Caravelas para chegar a Minas Gerais, com o objetivo principal de transportar madeira. Esse comércio foi acentuado como saída econômica, bem como o isolamento e a baixa densidade demográfica e a abertura de rotas de comunicação.

Um fato importante aconteceu no período da Segunda Grande Guerra Mundial (1939-1945): a região foi utilizada pelas Forças Aliadas na qual resultou na construção do Aeroporto de Caravelas graças a um acordo do Governo Brasileiro com o Governo Norte Americano, que tinha como estratégia manter um aeroporto na faixa litorânea no meio do caminho entre o Rio Grande do Sul e Maranhão. Ainda hoje é conservada a arquitetura militar da época: paredes espessas e arcos. O aeroporto também foi utilizado para manobras militares de treinamento durante a visita do Presidente Getúlio Vargas na década de 1940 considerado como o segundo do país em tamanho de pista.

Apesar de enfrentar problemas sociais para a população, como os precários serviços de saneamento básico, energia elétrica e atendimento médico, o município se fortalece como centro econômico e político da região, na qual era representado pelo movimento comercial em especial pelo Porto de Ponta de Areia e a Estrada de Ferro Bahia - Minas na qual exportavam alguns produtos como café, madeira e cacau. Face às mudanças na política nacional de transportes, a estrada de ferro foi 
desativada em 1966. Em meados do século XX o município entra em decadência, perde o seu referencial na região passando o legado para a cidade de Teixeira de Freitas, Itamaraju e Eunápolis.

Com o fenômeno da migração rural, a chegada das empresas de reflorestamento de eucalipto, os grandes pecuaristas e aqueles que desenvolvem atividades agrícolas, atraem a especulação imobiliária e a grilagem de terras cria questões sociais de forma exorbitante. A partir da segunda metade do século XX cidade perde a sua importância regional, principalmente pelo fortalecimento da criação de gado na região para abastecer o comercio local, o Rio de Janeiro e Belo Horizonte.

A partir dos anos de 1950 houve grandes mudanças na região proporcionadas por novos fatores principalmente pela atuação e investimentos de setores governamentais federais e estaduais como o Banco do Nordeste. Durante o governo militar (1960 a 1970), que tinha no bojo o caráter de desenvolvimento e integração coloca em pauta a obra da BR101 que faz com que a região do Extremo Sul da Bahia saia do isolamento possibilitando a circulação de mercadorias e pessoas, nas diversas estradas vicinais que são abertas para ligar a grande rodovia nacional. Dessa forma, em torno da BR 101 , acontece um rápido crescimento demográfico com a chegada de pessoas de vários estados e até de alguns países que se instalaram como moradores e/ou comerciantes. Após o seu declínio econômico e social, surgiu na cidade a expressão "Caravelas é a cidade que já teve" que traduz essa fase áurea. Hoje, a cidade está representada por tradições que são patrimônios preservados e valorizados.

Hoje, a perspectiva econômica e social do Município de Caravelas está voltada para os festejos carnavalescos com características de modernidade e marcas de tradição como o trio elétrico, além de escolas de samba. Também preserva grupos culturais e artísticos que referenciam datas especiais. Sua potencialidade econômica recai na produção de madeira para a indústria de celulose e papel que tem como principais as empresas multinacionais como a Fibria Celulose e Papel S/A e a Suzano Bahia Sul Celulose S/A. Outro aspecto que merece enfoque é o patrimônio histórico, constituído de edifícios com influência da arquitetura portuguesa concentrado nas ruas Barão de Mauá, Sete e do Porto. Essas construções do período colonial (casas, igrejas, prédios administrativos) não se encontram devidamente conservadas. Apesar de haver esse tipo de construção, não há uma política de preservação - umas foram demolidas e outras transformadas em lojas, bares e restaurantes.

\section{GINÁSIO SANTO ANTÔNIO DE CARAVELAS: ENSINO DE QUALIDADE}

O ano de 1952 registra o lançamento da pedra fundamental do Ginásio Santo Antônio marco importante na cidade de Caravelas. Foi um grande acontecimento para a educação, para a cidade e para toda a região e do seu entorno além de estados como Minas Gerais e Espírito Santo devido ser Caravelas referência regional e ter visibilidade além do seu território físico.

Para relatar o Ginásio Santo Antônio de Caravelas/BA, se faz necessário buscar a fundação da Campanha Nacional de
Escolas da Comunidade (CNEC) em 1943 por Felipe Tiago Gomes que se espalhou por diversos estados do Brasil com o intuito de formar ginásios de caráter comunitários. Posteriormente, houve a mudança de nome para Campanha Nacional de Educandários Gratuitos (CNEG) também conhecido por Rede Cenegista que espalharam rapidamente pelo estado da Bahia.

A presença significativa na educação brasileira via CNEG se fez através da atuação da educação infantil ao ensino superior, com unidades em todos os estados da federação, cuja estrutura de atuação contava com o apoio do poder público, pois tinha no seu meio a presença de representantes políticos.

No Brasil, até 1971, o ginasial constituía o estágio educacional que se seguia ao ensino primário e que antecedia o ensino colegial, que correspondia aos quatro anos finais do atual Ensino Fundamental. Para ter acesso ao ensino ginasial, era necessária a realização de um exame de admissão, que seria após o término do ensino primário. Os estudos ginasiais duravam quatro anos, e no final desta etapa, o aluno passaria ao colegial que se constituía no terceiro ciclo de estudos. Posteriormente com a LDB 5691/71, o ensino ginasial fundiuse com o ensino primário, originando-se o $1^{\circ}$ grau com duração de 8 anos. Hoje de acordo com a LDB 9394/96, o $1^{\circ}$ Grau passou a ser chamado de Ensino Fundamental.

O Ginásio Santo Antônio foi uma tradicional instituição de Ensino Fundamental II e Ensino Médio da cidade de Caravelas - Bahia, localizado na Rua das Palmeiras, no Bairro do Centro mantida pela CNEG, na qual tinha a contribuição das famílias de alunos que podiam pagar e a subvenção do poder municipal a fim de que todos os alunos fossem mantidos de forma igualitária na escola. Por suas salas de aula passaram personagens importantes de Região do Extremo Sul da Bahia, como alunos e/ou professores, os quais gozavam de prestígio e respeito na sociedade.

Como a educação é uma prática social e histórica, as instituições escolares produzem representações, valores, imagens e ideologias internalizadas no processo educativo e deixam marcas. A instituição escolar, em cada momento histórico, demonstra uma expressão, assim como uma resposta à sociedade na qual está inserida. Para contarmos a origem do Ginásio Santo Antônio faz-se necessário considerar a visão educacional no período da sua implantação, década de 1950. O ensino ginasial era normatizado pelas Leis Orgânicas de Ensino, que foram promulgadas no ano de 1942, durante o Estado Novo. Essas leis foram estabelecidas por Gustavo Capanema quando Ministro da Educação no período de 1937 a 1945 no governo de Getúlio Vargas.

O ensino, composto por quatro anos elementares do Ensino Primário, acrescido do primário complementar de um ano. Já, o Ensino Médio foi estruturado verticalmente em dois ciclos: o ginasial composto de quatro anos, e o colegial, com duração de três anos; e horizontalmente: no Secundário e Técnico-profissional, subdividida em industrial, comercial e agrícola, além do Curso Normal (SAVIANI, 2008).

Dada à importância do ginásio referido, a imprensa sempre o destacava pela seriedade e comprometimento com o ensino. A sua implantação foi a partir do empenho do $\mathrm{Sr}$. Moacyr de Jesus Siguara, membro de tradicional família caravelense, foi prefeito do município no período de 1955 a 1959. Segundo o Professor Francisco de Almeida Oliveira 
nesta época o prefeito Moacyr, embasado no seu objetivo de promover a educação local apoiou a criação do Ginásio Experimental 7 de Setembro, realização de um grupo de idealistas, como: juiz de direito, políticos, professores, profissionais liberais e igreja católica. A secretaria do educandário ficou sob a responsabilidade da $\mathrm{Sr}^{\text {a }}$ Guiomar Almeida Silva. Esse foi o embrião, com duração de apenas 2 anos, para a futura instalação do Ginásio Santo Antônio de Caravelas, cidade considerada "a capital da região" pelo seu grau de importância social, econômica e política da região mais distante da capital baiana.

Tamanha era a responsabilidade na formação dos seus alunos, que o Regimento Interno destaca no Título VI, Capítulo I, Artigo 73:

"Colaborar na formação moral e cívica dos alunos, por meio de palavras, atitudes e ações, fornecendo exemplos de elevado padrão de urbanidade, civismo e exatidão no cumprimento do dever; colaborar, igualmente, na formação católica dos educandos, quer pelo exemplo, quer pelos ensinamentos que em nada podem desviar-se da doutrina da Igreja (GINÁSIO SANTO ANTÔNIO, 1962, f. 12)."

A visibilidade do Ginásio Santo Antônio era grande, e havia certa exigência aos candidatos a alunos, como: idade mínima de 11 anos; ter concluído o estudo primário e ser aprovado no exame de admissão, que era uma seleção por meio de "prova" escrita. De acordo com Dino Priante (2012) em seu artigo "Admissão ao Ginásio" nos dá noção do que era o referido exame instituído em 1931, perdurou até o ano de 1971 - era o "fio da navalha". Na época, além das provas finais escritas, havia as provas orais, ocasião em que os alunos ficavam "tetê à tête" com a professora, e de dentro de uma sacola de pano, era sorteado o assunto pelo qual o aluno era sabatinado. Legalmente essa era a porta de entrada no Ginásio, pois, consta, no Artigo 32 do Decreto-Lei 4.244/09/04/1942 da Lei Orgânica do Ensino Secundário em que o aluno deveria:

a) Ter pelo menos onze anos, completos ou por completar até o dia 30 de junho e ter recebido satisfatória educação primária;

b) Ter revelado, em exames de admissão, aptidão intelectual para os estudos secundários.

Desta forma, o período pesquisado corresponde ao período no qual a Lei Orgânica de 1942 sustentava o ensino brasileiro do segmento do ensino secundário, destinado à formação das elites. Tal clientela era encaminhada ao ensino superior e para as posições mais privilegiadas e importantes da sociedade. Em relação à avaliação do Ginásio Santo Antônio os tipos eram diversificados como prova oral ou escritas, não poderia conversar com o colega e a "cola" era reprimida com rigor.

Por todo esse controle o número de repetências era elevado de acordo com os dados contidos nas Atas de Resultado Final e de acordo com Oliveira (2013) as turmas tinham que ser desdobradas em turmas A, B, C com aproximadamente 40 alunos, embora o espaço físico das salas fosse restrito. Além do trabalho pedagógico esta instituição tinha na disciplina outro controle dos alunos, pois "Havia um chefe de disciplina, o professor Gilberto, que mantinha a disciplina na entrada dos alunos e durante o recreio".

Esse rigor na disciplina era sempre em sintonia com a família que em caso de alguma gravidade os pais seriam chamados à escola e o aluno seria penalizado com suspensão das aulas por três dias. Caso nesse período o aluno perdesse alguma atividade avaliativa, a nota seria zero e só teria oportunidade de recuperá-la no final da unidade.

A instituição programava comemorações cívicas e sociais diversas com a participação da comunidade escolar e sociedade civil incluindo as autoridades locais. As comemorações cívicas eram comemoradas com patriotismo. o desfile escolar no Dia da Independência era acompanhado pela Banda Marcial e com parada em frente ao palanque oficial para ouvir o discurso do Sr. Prefeito Municipal.

Além do civismo que era exercitado na escola por meio do desfile escolar em seus pelotões de bandeiras, balizas e alegorias, outra festividade presente e de grande destaque na memória dos ex-alunos eram as Festas de Formatura principalmente pela relação de que a educação não era para muitos. Um número restrito da sociedade concluía o Ginásio e essa conquista era motivo de orgulho para as famílias e a escola fazia questão de se autopromover. Era um evento de grande repercussão na sociedade caravelense e dava um caráter solene com missa na catedral, entrega de certificados e baile onde os formandos e familiares se apresentavam com roupas de gala. Desta forma, o encerramento de um período de ensino tinha significativa carga simbólica.

Portanto, as festas de formatura traziam representatividade social e cultural, não era simplesmente a finalização do curso. A entrega dos certificados se dava durante a missa, momento de muita emoção para todos os envolvidos (famílias, formandos, professores e funcionários).

A festa de formatura é lembrada como momento de realização e comoção, porque estavam todos ali com as famílias, colegas, professores e toda a sociedade se voltava para este dia de felicidade. Ao analisarmos as festividades emanadas do Ginásio Santo Antônio de Caravelas percebemos que eram incorporados na prática escolar a fim de fomentar uma educação de Corpos, Mentes e Sentimentos, princípios norteadores dessa escola de qualidade.

\section{PROFESSORES, ESPAÇO DE VISIBILIDADE E CONVIVÊNCIA}

O ginásio Santo Antônio tinha em seu quadro de professores membros da sociedade com reconhecido nível de conhecimento representado pela "elite intelectual" que favorecia positivamente a imagem representativa da profissão e destaque para a escola por sua importância social, ou seja, pessoas proeminentes. O primeiro corpo docente (1957) formado pela sociedade civil e militar, teve expressiva representação de mulheres.

Segundo Barreto (2005, p.139)

"O universo escolar apresenta seu próprio conjunto de
padrões de representações, como podemos constatar a
partir de registros escolares cívicos, sociais e culturais,
presentes em álbuns, jornais, revistas e em arquivos." 
Os docentes eram sempre homenageados pelos alunos e seus familiares para enfocar os valores atribuídos à profissão. Neste sentido as homenagens eram diversas como as comemorações de aniversário. Essas comemorações referidas fizeram do espaço escolar um lugar privilegiado para a perpetuação de visões, imagens, concepções de ensino e de profissão docente, pois grande parte dos ex-alunos seguiu a carreira do magistério.

$\mathrm{Na}$ história de determinada Instituição Escolar não se pode abandonar a pesquisa referente aos professores que nela atuaram, bem como sua formação acadêmica Não podemos deixar de mencionar, portanto, tal aspecto na análise do Ginásio Santo Antônio. Questionados sobre o que mais gostavam e o que menos gostavam ou alguma recordação que ainda guardam na lembrança os alunos descreveram fatos variados como:

As festividades, a amizade entre alunos e professores, o convívio com os colegas, as brincadeiras, as festas e principalmente o aniversário dos professores, pois era dia de matar aula. Amélio João Andrade Siguara (estudou no Ginásio Santo Antônio no período de 1964-1967).

A organização, a disciplina, o respeito alunos / professores / diretor. As festas, dos aniversários dos professores que a minha turma organizava - festa da amizade. Gisélia Passos da Costa (estudou no Ginásio Santo Antônio no período de 1965-1969).

Reconstituir a história de uma instituição educativa por meio da memória e das lembranças é mostrar o passado e o presente, num movimento que reorganiza a identidade e a transforma, sempre num contexto histórico-social, no qual se desenvolveram suas relações enquanto pessoas que contribuíram para a formação social e educacional daqueles que tiveram acesso à instituição.

A instalação da Ditadura Militar e assinados acordos MEC - USAID disponibilizou recursos financeiros vindos dos Estados Unidos da América para a educação brasileira que possibilitaram a construção das Escolas Polivalentes. Esse novo modelo tinha o propósito de tornarem-se centros de excelência e servirem de modelo com a finalidade de preparar para a vida profissional os jovens. Dava suporte a sociedade no desenvolvimento industrial com mão de obra qualificada, conforme fundamentada na nova LDB $\mathrm{N}^{\circ} 5692 / 71$ que reformulou os ensinos de $1^{\circ}$ e $2^{\circ}$ graus $^{2}$ ofertando, além das disciplinas teóricas, as práticas agrícolas, industrial, comercial e educação para o lar.

E a partir dessa transição - Ginásio Santo Antônio e Escola Polivalente fica registrado a finalização histórica de uma época áurea da educação no Extremo Sul da Bahia, pois a criação do Ginásio Santo Antônio ainda é vista como um exemplo de coragem. A trajetória deste educandário se traduz em vitórias sobre obstáculos difíceis e ainda hoje serve de inspiração para a sociedade, principalmente aos jovens alunos na conquista dos seus sonhos, seja concluindo um curso superior, seja instruindo seus filhos, seja aprendendo a exercer o direito legitimo de cidadão brasileiro.

Hoje, o prédio abriga a sede da Escola Agripiniano de Barros onde funcionou o Ginásio Santo Antônio que tanto

\footnotetext{
${ }^{2}$ A partir desta LDB o $2^{\circ}$ Grau passou a ser profissionalizante e obrigatório.
}

orgulho ofereceu para a cidade na formação da juventude caravelense.

\section{CONCLUSÃO}

As afirmações aqui elencadas não podem considerar concluído essa pesquisa, uma vez que o estudo realizado para esse trabalho científico não expressa toda a realidade vivida no espaço do Ginásio Santo Antônio de Caravelas, pois remete, na verdade, a uma parcela das fontes documentais ou orais encontradas, disponíveis e em bom estado de conservação e manuseio. $\mathrm{Na}$ análise dessas fontes e durante todos os momentos deste estudo houve o interesse em conhecer, compreender e analisar os aspectos sócio-históricos do ginásio referido e como ele tornou-se um lócus de produção e expressão histórica durante a sua existência para a sociedade caravelense. Hoje é considerado um espaço de memória construída e vivida para aqueles que tiveram o privilégio de participarem ativamente e para os atuais educadores, alunos, pais e toda a sociedade.

Procuramos reconstruir um pouco da história do Ginásio Santo Antônio, desde a sua Genesis até a seu fechamento. Esperamos que, ao longo destes capítulos, possamos compreender melhor o seu valor e a sua identidade como "escola da cidade" e/ou "escola de qualidade", lembrança que ainda perdura no imaginário social.

Todos os empreendimentos para constatar que a representação de instituição escolar da região veiculada a ideia de metrópole regional que a cidade de Caravelas como referência por ser historicamente ligada a capital do estado da Bahia (Salvador) e a capital federal do Brasil (Rio de Janeiro, na época). Assim, entendemos que o ginásio ainda interfere na cidade, que além de todo o contexto social, comercial, político e econômico estão relacionados a fatores sentimentais vivenciados por aqueles que por lá passaram.

Neste entendimento a reconstituição da história de instituições escolares permite compreender o contexto da época e situar o debate sobre temas que, na atualidade, nos instigam a pensar e emitir opiniões na perspectiva de mudanças e organização dos espaços e ideias. Foi assim que buscamos as respostas nos questionários aplicados bem como na contribuição da educação local para o desenvolvimento regional. A pesquisa nos permitiu conhecer um pouco sobre a história da instituição, e nos proporcionou uma visão ampla da educação na década de 1950.

\section{REFERÊNCIAS}

BARRETO, Sônia Maria da Costa. Construção da imagem da normalista na Revista Vida Capichaba, no Espírito Santo, nos anos 1920. 2005. 220 f. Tese (Doutorado em Comunicação e Semiótica) - Pontifícia Universidade Católica de São Paulo, São Paulo, 2005.

BRASIL. Decreto-Lei $n^{o} 4.244 / 1942$ : decreta a Lei Orgânica do Ensino Secundário. 
BRASIL, Lei $n^{\circ}$ 5.692/1971. Fixa Diretrizes e Bases para o ensino de $1^{\circ}$ e $2^{\circ}$ graus, e dá outras providências.

CANCELA, Francisco Eduardo Torres. De projeto a processo colonial: índios, colonos e autoridades régias na colonização reformista da antiga capitania de Porto Seguro (1763-1808). Tese de Doutorado. Universidade Federal da Bahia, Faculdade de Filosofia e Ciências Humanas. Salvador, 2012. 337 f.

CERTEAU, Michel de. A Escrita da História. Rio de Janeiro: Forense-Universitária, 1982.

GINÁSIO SANTO ANTONIO. Regimento Interno, Caravelas, BA, 1962.

GONÇALVES, Janice. Pierre Nora e o tempo presente: entre a memória e o patrimônio cultural. Revista Historiae, v.3, n. 3. Universidade Federal do Rio Grande. Rio Grande, RS, 2012.

HOBSBAWN, Eric. A Era dos Extremos: O breve século XX (1914 - 1991). São Paulo: Companhia das Letras, 2012.

OLIVEIRA, Roberto Oto Loureiro de. Cineclube Caravelas: o cinema do Sul da Bahia. Dissertação (mestrado) - Pontifícia Universidade Católica do Rio de Janeiro, Departamento de Comunicação Social, 2013.

SAVIANI, Dermerval. História das ideias pedagógicas no Brasil. 2. Ed. Ver. e ampliada. Campinas, SP: Autores Associados, 2008.

\section{COPYRIGHT}

Direitos autorais: Os autores são os únicos responsáveis pelo material incluído no artigo.

Submetido em: 10/10/2018

Aprovado em: 12/02/2019 


\author{
Revista SODEBRAS - Volume 14 \\ $\mathrm{N}^{\circ} 158$ - FEVEREIRO/ 2019
}

\title{
EDUCAÇÃO MATEMÁTICA: REPRESENTAÇÕES SOCIAIS DE ALUNOS DO $5^{\circ}$ ANO DAS SÉRIES INICIAIS DO ENSINO FUNDAMENTAL I
}

\author{
MATHEMATICAL EDUCATION: SOCIAL REPRESETATION OF \\ STUDENTS IN THE 5 TH YEAR OF THE INITIAL GRADES OF \\ ELEMENTARY SCHOOL I
}

\author{
CARLOS LUIS PEREIRA ${ }^{1}$; EDSON RODRIGUES DOS SANTOS ${ }^{2} ;$ MARIA DO CARMO DE LIMA $^{3}$; \\ LUIZ CLAUDIO MORO AIOFFI ${ }^{4}$; RAFAEL ROLDI DE FREITAS RIBEIRO ${ }^{5}$; ADEMIR HILÁRIO DE \\ SOUZA $^{6}$; CRISTIANO DE ASSIS SILVA ${ }^{7}$ \\ 1 - PROFESSOR DOUTOR EM ENSINO DE CIÊNCIAS E MATEMÁTICA- UNICSUL - UNIVERSIDADE \\ CRUZEIRO DO SUL - SP; 2 - ESCOLA MUNICIPAL DE TEMPO INTEGRAL MOACIR AVIDOS - \\ VITÓRIA - ES; 3 - PREFEITURA MUNICIPAL DE TIMÓTEO - MG; 4 - MESTRE EM CIÊNCIA, \\ TECNOLOGIA E EDUCAÇÃO - GESTOR ESCOLAR- ARACRUZ - ES, SECRETARIA ESTADUAL DE \\ EDUCAÇÃO; 5 - PROFESSOR NO CURSO DE DIREITO NA FACULDADE NOSSA SENHORA DE \\ FÁTIMA - ES - FACULDADE NOSSA SENHORA DE FÁTIMA - ES; 6 - PROFESSOR DOS CURSOS DE \\ MEDICINA -UNIVERSIDADE REDENTOR-RJ E FAMESC - RJ - UNIVERSIDADE REDENTOR- \\ RJ/FACULDADE-FAMESC-RJ; 7 - PREFEITURA MUNICIPAL DE PRESIDENTE KENNEDY-ES \\ carlosluispereira_331@hotmail.com;edson_es@oi.com.br;marialimaadv@gmail.com;aioffi@gmail.com; \\ rafaelroldi@gmail.com; ademirhilario@oi.com.br;cristiano.wc32@gmail.com
}

\begin{abstract}
Resumo - O manuscrito tem como preposição a Educação Matemática e a Teoria das Representações sociais de Serge Moscovici. A Matemática tem sido uma das principais causas do fracasso escolar da Educação Básica e, como aponta as avaliações de larga escala divulgado pelos dados recentes do Sistema de Avaliação da Educação Básica, cerca de $70 \%$ do alunado brasileiro apresenta dificuldade de aprendizagem. A finalidade do artigo foi apresentar os resultados obtidos dos 450 do $5^{\circ}$ ano sujeitos da pesquisa sobre suas representações sociais sobre a Matemática. $O$ estudo foi dentro da abordagem qualitativa e utilizou-se à técnica de Livre Associação. Os resultados indicaram que as palavras: dificuldade, medo, reprovação, incapacidade, recuperação, número, tabuada e angústia prevaleceram nos discursos dos alunos. Conclui-se que a representação social positiva ou negativa sobre a Matemática construída dificilmente as transformarão no processo educativo.
\end{abstract}

Palavras-chave: Matemática. Aluno. Pedagoga. Representações Sociais. Ensino Fundamental I.

Abstract - The manuscript has as a preposition the Mathematical Education and Social Representation Theory of Serge Moscovici. Mathematics has been one of the main causes of school failure in Basic Education and, as the large-scale evaluations published by the Basic Education Assessment System points out, about $70 \%$ of Brazilian students have learning difficulties. The purpose of the article was to present the results obtained from the 450 of the 5 th year subjects of the research on their social representations on Mathematics. The study was within the qualitative approach and was used to the technique of Free Association. The results indicated that the words: difficulty, fear, disapproval, disability, recovery, number, tableau and anguish prevailed in the students' speeches. It is concluded that the positive or negative social representation of constructed mathematics will hardly transform them into the educational process.

Keywords: Mathematics. Student. Pedagogue. Social Representations. Elementary School I.

\section{INTRODUÇÃO}

A Educação Matemática conforme indicadores de larga escala do governo federal tem sido atribuído como uma das principais disciplinas responsáveis pelo fracasso escolar dos alunos em todos os níveis e modalidades de ensino. As principais pesquisas advindas de pesquisadores da área têm apontado que mesmo diante das principais tendências para o seu ensino na sala de aula pouca mudança tem ocorrido em sala de aula visando aumento da aprendizagem de todos os alunos. Conforme dados de 2017 divulgados em Agosto de 2018 pelo Sistema de Avaliação da Educação Básica (SAEB) revela que $70 \%$ do alunado brasileiro apresentam dificuldade para aprender conceitos científicos matemáticos, nessa mesma direção outros instrumentos avaliativos a saber o Programa Internacional de Avaliação de Alunos (PISA), O Exame Nacional do Ensino Médio (ENEM) e, a Prova Brasil apresentam dados similares.

Estes resultados insatisfatórios indicam a necessidade de pesquisas maior esclarecimento deste problema que afeta todo o cenário da educação brasileira, em particular da matemática escolarizada das séries iniciais, cujo indicadores apontam a falta de competências básicas sobre as quatro operações matemáticas básicas, fração simples, porcentagem, resolução de problemas do cotidiano que exigem saberes de matemática.

Pesquisadores da Educação Matemática no Brasil a citar Fiorentini e Lorenzato (2012) e D’Ambrósio (2012) e Bicudo (2018) apontam que inúmeros fatores corroboram para tal quadro exposto e, conforme estes autores, cabe ressaltar que a Prova Brasil é a avaliação oficial do governo federal para todas escolas públicas brasileiras que coleta, 
trata e dissemina informações estatísticas, avalia os acertos e erros dos alunos, quer dizer o conteúdo é avaliado estritamente na dimensão quantitativa, desconsiderando o conteúdo nos aspectos procedimentais e atitudinais e, também em descompasso com as Diretrizes Curriculares Nacionais que orienta para avaliar o aluno no enfoque da avaliação qualitativa e processual e, ainda respeitando o ritmo de aprendizagem de cada aluno.

Aqui, neste manuscrito focalizamos em investigar acerca das representações sociais de alunos do $5^{\circ}$ ano das séries inicias do Ensino Fundamental I sobre a matemática. As principais perspectivas teóricas recorridas nesta pesquisa sobre Teoria das Representações Sociais a saber: Moscovici (1961; 2012, 2013), Jodelet (2011), Chartier (2002) Wolski (2017) e Silva e Silva (2013) estes autores apresentam subsídios teóricos que nos permite compreender o fracasso dos alunos do $5^{\circ}$ ano na disciplina de matemática, ao elucidar a representação social destes sujeitos, construídas nas relações individuais e coletivas.

Nos escritos originais de Serge Moscovici (1961) concebia a representação social sobre a matemática do aluno é uma construção sociocultural construída individualmente e coletivamente tendo influência em toda sua trajetória escolar. A teoria da representação social contribui ao esclarecer que os sujeitos possuem representações sociais sobre determinado objeto, que dificilmente o aluno as transformarão no processo educativo, porque a dimensão cognitiva pela qual os alunos constroem as suas representações sociais sobre a matemática advém do fato do aluno está inserido num determinado contexto, em situações de interação social, surgindo as representações como cognição social, porque os alunos são sujeitos sociais, estes têm valores, crenças e modelos disseminados no seu grupo sobre a matemática seja uma representação positiva ou negativa.

Nesta esteira de discussão Jodelet (2011) e Dias e Dias (2013) apresentam uma colocação instigante, requer profundas reflexões teóricas dos educadores da área de todos atores educacionais e familiares. No paradigma das autoras como o aluno constrói a sua representação da matemática em sua estrutura cognitiva seja positiva ou negativa tem estreita correlação com a sua aprendizagem no decorrer de todo o processo educativo da Educação Básica.

Nos dados recentes do Saeb de 2017 apontou que em matemática os alunos tiveram o pior desempenho desde 2001 e, a aprendizagem estagnou no $5^{\circ}$ ano, $9^{\circ}$ e na $3^{a}$ série do Ensino Médio (BRASIL, 2017).

Delimitou-se como objeto de investigação alunos do $5^{\circ}$ ano porque os alunos são avaliados em indicadores de larga escala.

Para Ujiie et al (2017) na avaliação oficial do governo federal não têm possibilitado um diagnóstico global importante para avaliar os resultados já anunciados no texto. $\mathrm{Na}$ vertente teórica de Moscovici (2012) essa forma e avaliar não permite identificar quais as representações sociais que os alunos do $5^{\circ}$ ano atribuem à matemática, quer dizer qual a imagem sobre este objeto social eles constroem nas interações individuais e coletivas.

A problemática deste manuscrito foi apresentar os resultados obtidos de 450 alunos do $5^{\circ}$ ano das séries iniciais do Ensino Fundamental I sobre as Representações sociais atribuídas a Matemática devido ao rendimento insatisfatório na Prova Brasil tendo como média 205,1 enquanto o esperado é a partir de 224. Na escala de proeficiência os alunos revelaram domínio insatisfatório das quatro operações básicas da matemática, fração e porcentagem, apenas $40 \%$ dos alunos estão com conhecimento adequado e $33 \%$ dos alunos nos mais baixos níveis de aprendizagem. De acordo com o Ministério da Educação é o pior resultado desde 2005 conforme assinala os indicadores governamentais.

As dificuldades recorrentes dos alunos do $5^{\circ}$ ano em matemática divulgados nos resultados de indicadores de espectro escala do Ministério da Educação (MEC) têm sido discutidos pelos pesquisadores em Educação Matemática a influência positiva ou negativa da representação social sobre a matemática que os alunos atribuem a essa disciplina. As pesquisas recentes de assinalam que nas representações sociais dos alunos possuem sobre a matemática seja positiva ou negativa tem implicações no processo de ensino e aprendizagem (UJIIE et al, 2017).

No evento de 2018 do Encontro Nacional de Educação Matemática (ENEM) e de pesquisas da Sociedade Brasileira de Educação Matemática têm apresentado pesquisas associando a Educação Matemática com a Teoria das Representações Sociais postulada por Moscovici (2013) o autor defende que a aprendizagem do aluno em matemática depende da representação social sobre a matemática positiva ou negativa construída na estrutura cognitiva do aluno.

Trabalhos amplamente aceitos por pesquisadores da área já citados no texto mostram que os alunos dos anos iniciais possuem em maior prevalência representações sociais negativas sobre a matemática advinda do seu contexto sociocultural que dificulta a aprendizagem dos conteúdos de ensino de referência nacional comum determinado pelas Diretrizes desta área de conhecimento (JODELET, 2011).

Nesta mesma esteira de discussão as representações sociais sobre matemática dos alunos do $5^{\circ}$ ano permeadas por imagem negativa da disciplina como "somente para os sabichões" " somente para os gênios", "os cdf da sala" na qual excluem a maior parcela de alunos como aponta os indicadores do Saeb de 2017 ao revelar dificuldades elementares das quatro operações matemáticas, frações, porcentagem, e para aplicar no cotidiano os conhecimentos matemáticos escolares. Porém carecemos de mais estudos especificamente sobre este objeto e, para respaldar à investigação recorreu-se aos aportes teóricos aceitos amplamente pela literatura nacional e internacional (MOSCOVICI, 2013).

Respaldado pelo teórico acima, uma questão atualmente debatida entre os pesquisadores em Educação Matemática tem questionado acerca das representações sociais individuais e coletivas sobre a matemática que os alunos constroem colabora para os elevados índices apontados pelos indicadores do SAEB que têm revelado que desde 2001 rendimento insatisfatório do alunado brasileiro.

Justifica-se este trabalho apoiado em Jodelet (2011) a afirmar que a representação matemática negativa dos alunos do $5^{\circ}$ ano é devido à dificuldade em dominar as competências básicas das operações matemáticas básicas.

Destaca-se como justificativa neste estudo que os elevados índices de rendimento insatisfatório dos alunos em matemática do $5^{\circ}$ ano conforme aponta a Prova Brasil não se restringe a dimensão cognitiva e, sim a representação social que o aluno construiu em sua trajetória sociocultural.

Elencamos como justificativa que este estudo elucida traz à luz a representação social de alunos do $5^{\circ}$ ano sobre a 
matemática, aspecto desconsiderado nas avaliações de larga escala.

Em relação ao problema guisa de investigação, tomamos como ponto de partida os resultados aquém do esperado já citados neste texto. Será que se as representações sociais que os alunos do $5^{\circ}$ ano atribuem sobre a matemática corrobora para os resultados insatisfatórios divulgados pelo Ministério da Educação?

A hipótese aqui levantada sugere que o problema do insucesso na disciplina de matemática dos alunos do $5^{\circ}$ ano está imbricada com as representações sociais negativas que os alunos fazem da matemática.

O objetivo geral do artigo foi apresentar os resultados obtidos coletados das representações sociais sobre a matemática de 450 alunos do $5^{\circ}$ ano das séries iniciais do Ensino Fundamental I, de escolas públicas do Norte do Estado do Espírito Santo.

\section{REFERENCIAL TEÓRICO}

O Conceito de representação social noção fundamental no desenvolvimento deste trabalho tem sua origem no conceito de pensamento coletivo defendido na teoria sociológica de Durkheim (2001). Para o próprio autor a vida social é essencialmente construída de representações individuais e coletivas, permeadas pelo senso comum, os mitos, e estão na base das representações dos sujeitos, que por sua vez estão associadas à consciência individual do sujeito. A Teoria das Representações Sociais o arcabouço teórico deste estudo foi postulado por Serge Moscovici (1961) embasado no citado autor essa abordagem sociopsicológica, um fenômeno psicossocial tendo origem nos trabalhos de Durkheim na qual tem como proposição possibilitar um novo olhar sobre os indivíduos e sobre as suas interações sociais, construídas nas relações com os sujeitos.

$\mathrm{Na}$ acepção de Moscovici (2013, p.13) as representações sociais "São conhecimentos práticos que se desenvolvem nas relações do senso comum, são formadas pelo conjunto de ideias da vida cotidiana, as vezes construídas em interações individuais ou grupais". Ainda para o mesmo autor na sua ótica a relevância da teoria das representações sociais consiste em atuar como instrumento para análise da realidade social, propondo compreender o olhar dos sujeitos e objetos.

Na definição de Jodelet (2011) a representação social é apresentada como modalidades de conhecimento prático orientadas para a comunicação e, para a compreensão do contexto social em que vivemos, pois, cada sujeito é permeado por uma realidade social e cultural.

$\mathrm{Na}$ visão de Wolski (2017, p.24) “As representações sociais são responsáveis pelo processamento psicossocial que acontece com um grupo". Na assertiva de Chartier (2002) as representações sociais são concebidas como classificações e divisões que organizam a apreensão do mundo social como categorias de percepção do real, estas produzem discursos, práticas e estratégias afim de impor uma autoridade e mesmo legitimar escolhas.

$\mathrm{Na}$ perspectiva teórica de Minayo (1995, p.108) “As representações sociais se manifestam em palavras, sentimentos e condutas e se institucionalizam na escola". Portanto podem e devem ser analisadas a partir da compreensão de estruturas e dos comportamentos sociais, principalmente nas relações familiares e com grupo na qual está inserido.
De acordo com Campos (1996) embasado em Freud, nos esclarece acerca das representações sociais dos alunos sobre a matemática dentro desta perspectiva teórica, para ele existe uma energia física que governa os fenômenos naturais e também existe uma energia psíquica que influi diretamente sobre o comportamento humano. E para o autor se alguma atividade (matemática escolar) o aluno não se sente bem executando-a, não se sente bem estar físico e emocional e mental, institivamente irá recusá-la, rejeitá-la, na maioria das vezes em algum momento os alunos tiveram momentos negativos com a aprendizagem da matemática a questão é como o aluno constrói em suas estruturas psíquicas tal representação, estas que dificilmente se transformarão no processo educativo.

Ainda na vertente teórica de Campos (1996) as experiências desagradáveis principalmente nas séries iniciais $\left(1^{\circ}\right.$ ao $5^{\circ}$ ano), tem potencialidade para provocar no aluno aversão, rejeição, medo, pavor agravando a sua dificuldade para o aprendizado,

No posicionamento de Machado e Cordeiro (2015) a construção da representação social sobre a matemática do professor das séries iniciais tem estreita correlação com as construídas gradativamente pelos alunos trazendo implicações positivos ou negativos em todo o processo educativo do aluno em toda trajetória da Educação Básica.

Sobre essa discussão nos escritos de Pereira e Hilário (2015) aponta que os formandos em Pedagogia, na formação inicial possuem formação incipiente sobre os conteúdos curriculares de matemática, ressaltando que na organização curricular se faz presente prática de ensino e metodologia de ensino da matemática. Na assertiva destes autores os saberes disciplinares e curriculares sobre a matemática do professor pedagogo e na prática educativa há reflexo da formação precária e da dificuldade de alunos e professores (pedagogos) sobre a matemática.

$\mathrm{Na}$ afirmativa de Wolski (2017) a representação matemática que os professores dos anos inicias construíram negativamente, são no decorrer no processo educativo transmitidas aos alunos gradativamente e associando aos fatores negativos adquiridos na coletividade corroboram para às suas representações sociais.

Na afirmativa de Moscovici (2013) e Silva e Silva (2013) a maioria dos alunos possuem representações sociais sobre matemática relacionada a fatores emocionais carregadas de frustrações, angústias, inseguranças, a convicção de incapacidade para aprender, aversão à matemática, associa-se a tristeza, dor, raiva, fracasso, medo, recuperações, dificuldade para fazer cálculos, baixa estima,

Ainda conforme a perspectiva teórica de Moscovici (2012) e Silva e Silva (2013) as representações sociais sobre a matemática positiva ou negativa construídas pelos alunos dos anos iniciais seja individual ou coletiva têm associação com imagem da matemática construída pela professor/a, família e amigos, estes atores sociais transmitem aos alunos/filhos à sua expectativa, frustração, fracasso, dificuldade, sentimentos negativos sobre a matemática construída na sua trajetória pessoal.

$\mathrm{Na}$ exposição teórica de Nóvoa (2009) e Almeida (2011) nos convida à profunda reflexão porque para ele o professor de matemática dos anos iniciais ensina aquilo que ele sabe e que reflete naquilo que somos, e naquilo que somos, se encontra muito daquilo que ensinamos. E, tal representação tem profunda relação com as representações sociais dos alunos, em particular do $5^{\circ}$ ano, estes que na 
Prova Brasil vem tendo resultados insatisfatórios, porque há poucas pesquisas que propõe ampliar as investigações acerca do fracasso do aluno brasileiro em matemática, visto que nos países como Argentina, Chile, Cuba, Uruguai, os países asiáticos, Finlândia, Noruega, Suíça, Suécia e Canadá os alunos conforme os indicadores internacionais apresentam resultados satisfatórios (PISA,2015).

Aqui no Brasil o governo tem investido em políticas públicas principalmente no que se refere a formação continuada de professores, indicadores mostram melhorias, importantes avanços porém na disciplina de matemática os resultados obtidos em avaliações institucionais e nas de larga escala, revelam aprendizagem insatisfatória dos alunos da rede pública de ensino em todo processo educativo da Educação Básica, aqui nesta pesquisa o foco foi no $5^{\circ}$ ano das séries iniciais, cujo indicador é realizado pela Prova Brasil.

$\mathrm{Na}$ preposição de Abric (2001) os alunos do $5^{\circ}$ ano têm as suas representações sociais, julgamentos, atitudes e imagem construída sobre a matemática elaboradas e reelaboradas pelo seu grupo social a questão central tem sido que suas representações não são reconhecidas e validadas na escola, e nas avaliações de larga escala aplicadas pelo MEC.

Seguindo essa discussão na assertiva de Bicudo (2018) uma das questões centrais que tem influência acerca da representação social do aluno das séries iniciais sobre a matemática é evidenciado pela autora a formação inicial dos professores de matemática, que ainda tem sido dentro do modelo da corrente pedagógica tradicional, essa que valoriza a memorização descontextualizada dos conhecimentos científicos.

Sobre essa questão concordamos com Julia (2001) ao afirmar que a representação social da matemática pelo aluno é produzida na sala de aula e, em geral pela cultura escolar que é padronizada para cumprir as exigências do currículo prescrito, que desconsidera as experiências, as vozes, as representações dos alunos e, prioriza a dimensão quantitativa e somativa das notas.

$\mathrm{Na}$ colocação Lima (2014) e Bicudo (2018a) a representação social sobre a matemática construída pelos sujeitos desta pesquisa têm implicações com seus valores, ação afetiva e a imagem de si próprio sobre sua capacidade para aprender matemática.

Nesta mesma linha de pensamento Chartier (2002) e Almeida (2011) apontam que as representações sociais sobre a matemática dos alunos do Ensino Fundamental I e dos professores estão articuladas com: elementos afetivos, mentais, sociais e culturais. Os autores destacam que as representações sociais das famílias sobre a matemática sobre si próprios são na maioria das vezes negativas e os alunos afirmam que não sabem nada de matemática, reproduzindo as falas das famílias, da escola, do professor de matemática, dos colegas e de própria imagem negativa de si sobre a matemática.

Dialogando com os autores supracitados no parágrafo acima a representação social sobre a matemática citadas em sua maioria são negativas, sinalizando a visão, o sentimento e o medo que os alunos possuem da matemática e estes sentimentos são similares com os das professoras pedagogas entrevistadas, sendo assim a construção da representação social individual sobre a matemática determina o ensino e aprendizagem desta ciência em todo processo educativo.
Entendendo essas falas dos alunos e professores na exposição teórica de: Minayo (1995); Wolski (2017) e Bicudo (2018) concebem a representações social do sujeito se manifesta em palavras, sentimentos, condutas, atitudes sobre um dado objeto". Dialogando com a autora ao mapear as representações sociais dos alunos pesquisados sobre a matemática as palavras mais encontradas entre estes sujeitos nas interações grupais dentro e fora do ambiente escolar e principalmente nos diálogos com os familiares a saber: agonia, nervosismo, reprovação, preocupação, número, contas, cálculo, atenção, ignorante e exigente. Conforme explica Husserl (2007) é nas representações sociais destes alunos sobre a matemática encontra-se explicações na fenomenologia porque um enfoque segundo este autor é que tal método descreve as experiências dos sujeitos no cotidiano, seus problemas, percepções e visão de mundo.

Conforme apontam Wolski (2017) e D’Ambrósio (2012) ainda prevalece na matemática a visão positivista de ensino, essa reconhece e valoriza no aluno a sua capacidade cognitiva desconsiderando as dimensões afetivas, sociais, culturais e familiares que são importantes na construção positiva do aluno sobre a matemática.

$\mathrm{Na}$ vertente de Jodelet (2011) e Silva e Silva (2013) na representação social dos alunos sobre matemática a fala de não conseguirem aprender matemática faz parte também do discurso de professoras pedagogas essa representação social destes sujeitos estão imbricadas de tal forma que as frustrações, angústias, insucesso, reprovação e até evasão escolar pela alta incapacidade para aprender matemática, gerando em alguns alunos depressão.

De acordo com Minayo (1995) e Bicudo (2010;2018) a representação social sobre a matemática da professora pedagoga em muito se deve à ausência na formação inicial docente de saberes disciplinares, curriculares, profissionais e experienciais sobre a matemática e, também porque a mesma não escolher a docência desta disciplina essa questão contribui para gerar maior frustração, angustia e a certeza da incapacidade para ensinar os conteúdos científicos de matemática do ensino fundamental I de referência nacional comum.

\section{ENCAMINAMENTO METODOLÓGICO}

Neste estudo em relação à delimitação metodológica o mesmo enquadra-se dentro do método qualitativo e, em relação a finalidade o estudo teve caráter exploratório; Em relação a abordagem enquadra-se dentro da pesquisa qualitativa; Em relação método foi aplicado o Teste de Associação Livre seguindo as orientações de Mazzotti (2002) e Abric (2001). Este método proposto de maneira particular pela teoria do núcleo central, consiste em extrair dos pesquisados palavras relacionadas com o tema apresentado aos 450 sujeitos pesquisados, e na explicação dos autores este método permite trabalhar com muitos sujeitos, em um curto espaço de tempo.

Este estudo teve associação entre a investigação dentro da fenomenologia conforme orientam Husserl (2007) e Bicudo (2010), para o autor uma das características deste tipo de pesquisa consiste em conhecer a realidade social e cultural e educacional dos sujeitos, bem como suas percepções, experiências realizadas na vida cotidiana e escolar e da pesquisa do tipo fenomenológica em Educação Matemática seguindo as orientações de Bicudo (2010); Sobre as técnicas de coletas de dados foi realizado à aplicação do questionário sociocultural com seis questões, 
este pois visa a identificação e descrição dos sujeitos ,que podem auxiliar na compreensão das representações sociais identificadas este questionário teve como finalidade identificar aspectos sociais e culturais relativos à identidade de cada sujeito investigado. As questões propostas foram:

1) Quando se fala de matemática o quê vem em sua mente? 2) Quais as memórias positivas e negativas você tem sobre a matemática? 3) Qual disciplina você tem medo? 4) Qual Disciplina você tem maior dificuldade de aprendizagem ? 5) Você gosta de Matemática? 6) Qual a representação social a sua família tem sobre a matemática $\mathrm{E}$, para registar as questões respondidas foi utilizado o diário de bordo e em seguida as questões foram transcritas para análise dos dados coletados.

O ambiente da pesquisa foi em 06 escolas da rede pública municipal de ensino no Norte do Estado do - ES; A pesquisa de campo foi realizada entre os meses de agosto a outubro entre os turnos matutino e vespertino deste ano letivo.

Os sujeitos da pesquisa foram 450 alunos do $5^{\circ}$ ano das séries iniciais do Ensino Fundamental I. O critério de escolha para escolha do $5^{\circ}$ ano para investigação, foi devido a Prova Brasil aplicadas nacionalmente e os dados serem de domínio público. Os dados qualitativos analisados foram segundo a metodologia qualitativa da Bardin (2011). Para melhor elucidação dos dados coletados e, em seguida analisados, os mesmos foram apresentados em várias respostas a partir de dados numéricos bem como ensina Trivinõs (2017).

\section{RESULTADOS E DISCUSSÕES}

Quando na questão 1 serem perguntados o quê vem em sua mente quando se fala a palavra matemática os alunos puderam apontar até duas opções.

Os resultados coletados mais recorrentes dos 450 alunos são apresentados seguindo à técnica de associação livre conforme orienta Mazzotti (2002) e Abric (2001) na qual os alunos tornam o subconsciente em consciente. No (Quadro 1) a seguir foram revelados os resultados obtidos.

Quadro 1- Representação Social dos Alunos $5^{\circ}$ Ano da Matemática

\section{Dificuldade - 90 \\ Medo -15 \\ Horror - 20 \\ Reprovação- 40 \\ Decorar- 15 \\ Tabuada -17 \\ Rigor- 08}

Fazer inúmeros de exercícios - 50

Memorização - 38

Não entra na minha cabeça as explicações- 25

Muito difícil -55

Número e mais número - 23

Dificuldade para decorar - 31

Não sei nada, por mais que a professora ensina -24

Fracasso - 33

Me sinto ignorante -14

Pior aula da escola -25

Não aceita erros -18

Complicado as quatro operações matemáticas - 26

Chato - 12

Contas e mais contas - 15

Notas Baixas - 15

Tristeza - 34
Alegria - 18

Raiva - 19

Silêncio total na aula -25

Atenção - 23

Dor de cabeça Inteligência -22

Gênios -21

Nunca vou aprender- 12

Cálculo - 27

Me faz chorar -19

Aulas chatas -27

Rejeição - 19

Fonte: Dados do autor, 2018.

Nas respostas dos sujeitos da pesquisa constata-se que a representação social dos alunos pesquisados sobre a matemática de forma feral foram negativas e, ainda nota-se que 90 vezes a palavra dificuldade esteve presente no discurso dos alunos na explicação de Moscovici (2012; 2013) para estas respostas, são decorrentes da construção da representação social sobre a matemática que estes alunos já possuem no $5^{\circ}$ ano das séries iniciais do Ensino Fundamental I, mostrando que tal representação como afirma o autor é reproduzida no seu meio social a partir das interações com os sujeitos.

$\mathrm{Na}$ questão 2 foram perguntados sobre as representações sociais positivas e ou negativas sobre a matemática.

No (Quadro 2) revela os dados coletados. As respostas coletadas e divulgadas pelos 450 sujeitos da pesquisa nesta questão ocuparam-se a centralidade da pesquisa em detrimento do problema de pesquisa tomado para investigação.

Quadro 2 - Representações Sociais sobre Matemática dos Alunos do $5^{\circ}$ Ano

\section{POSITIVAS}

A paciência da professora para ensinar;

A ajuda dos colegas para resolver os exercícios;

A olimpíada de matemática entre as turmas de $5^{\circ}$ ano;

Os jogos pedagógicos usados.

\section{NEGATIVAS}

Por mais que a professora explica, não entendo nada;

As críticas dos colegas diante das minhas dificuldades;

Minha família reforça que sou incapaz de aprender;

Não conseguir tirar notas e, ficar sempre de recuperação;

Percebo que os grupos de excluem para os trabalhos porque não sei a matéria;

A professora me olhar como se eu não conseguisse aprender, porque ela disse que já explicou várias vezes.

Fonte: Dados do autor, 2018.

Verifica-se que os discursos mais recorrentes foram os anunciados no (Quadro 2), nas representações positivas percebe-se que os alunos reconhecem dois fatores importantes a didática da professora para ensinar e, o processo de interação entre os colegas para resolução de atividades em sala de aula. Na explicação de Jodelet (2011) tais construções positivas serão importantes em todo o processo de ensino e aprendizagem dos conteúdos curriculares da matemática escolar e para Moscovici (2013) estes alunos na coletividade construíram representação social positiva sobre a matemática. Em contrapartida nota-se que prevaleceram as representações sociais negativas sobre 
a matemática, conforme explica Campos (1996) respaldado por Freud, por algum motivo estes alunos, construíram aversão, repulsa, ódio, raiva e tristeza sobre a matemática escolarizada, tal sentimento de energia psíquica negativa, dificilmente serão transformadas no processo de ensino e aprendizagem, neste sentido todos os conteúdos curriculares os alunos apresentam sentimento negativo e desmotivação para aprender.

Em relação a questão 3 ao serem perguntados sobre a disciplina que mais tenho medo?

No discurso dos alunos verifica-se que $87 \%$ atribuem à Matemática, devido a dificuldade para aprender as quatro operações matemáticas e de expressar dentro da linguagem matemática. Para responder este resultado verificado nas palavras de Moscovici (2012;2013) e Jodelet (2011) as representações sociais dos alunos sobre a matemática, em particular construídas nas séries iniciais dificilmente serão modificadas pelo sujeito.

Ao serem questionados na questão 4 sobre a disciplina que apresentam maior dificuldade para aprender?

No (Quadro 3) a seguir foram anunciadas as respostas dos 450 sujeitos da pesquisa.

Quadro 3- Dificuldade em aprendizagem nas disciplinas

\begin{tabular}{c}
\hline Matemática 47\% \\
Língua Portuguesa 42\% \\
Ciências Naturais 5\% \\
Geografia 3\% \\
História 3\% \\
Educação Física 0\% \\
Ensino Religioso 0\% \\
\hline Fonte: Dados do autor, 2018.
\end{tabular}

Para responder essa questão recorreu-se aos dados recentes do SAEB de 2107 divulgados em Agosto de 2018 ao revelar que $70 \%$ do alunado brasileiro têm dificuldade para aprender matemática, em particular no $5^{\circ}$ ano $33 \%$ dos alunos não possuem conhecimentos matemáticos básicos sobre as quatro operações matemáticas básicas, $40 \%$ possuem nível de aprendizagem dentro do esperado e $27 \%$ não conseguem no cotidiano resolverem questões que dependam da matemática.

Quando foram perguntados na questão 05 se gostavam da disciplina de matemática?

Conforme os dados revelados os dados coletados indicaram que:

$19 \%$ Alguns conteúdos de ensino

$57 \%$ Não

$24 \% \mathrm{Sim}$

De acordo com Julia (2001) a cultura escolar tem implicações acerca das representações positivas ou negativas sobre as matemática construídas pelos alunos, principalmente os dos anos iniciais porque a estes sujeitos foi apresentado no currículo praticado uma matemática permeada pela dificuldade para aprender e Chartier (2002) acrescenta que a partir da cultura escolar de como tem sido ensinada a matemática o aluno dos anos iniciais constroem a representação social positiva ou negativa sobre a matemática, nos dados mostrados evidencia que dos 450 alunos pesquisados mais de $50 \%$ não gostam de matemática, no discurso dos alunos conforme explica estes Campos (1996) e Wolski (2017) está diretamente relacionado com as experiências negativas de ordem psíquica , iniciadas no processo de ensino e aprendizagem da matemática das séries iniciais do Ensino Fundamental, tal experiência negativa tem reflexo durante todo o processo educativo da Educação Matemática na Educação Básica.

Na questão 6 foi perguntado no discurso da família qual a representação social sobre a matemática?

Os resultados coletados mais recorrentes nos discursos dos alunos foram as citadas a seguir:

"Minha mãe disse, que devo ficar em silêncio na aula para aprender as contas".

"Novamente você, em recuperação em matemática, eu também ficava quando era aluna".

"Eu também sempre fui péssima aluna de matemática, fui reprovada dois anos no colegial”.

"Odeio, fui reprovada por causa de 1 ponto, tomei raiva da matéria”.

"Nem eu e nem seu pai, éramos bons em matemática, detestava esta matéria e do professor um carrasco com a turma".

"Tem coisa que aprendi em matemática que nem sei para quê".

"Somente conseguia tirar nota mediana, nunca fui boa aluna”.

"Sempre tive muita dificuldade em matemática, meus filhos têm as mesmas dificuldades".

"Chorava muito porque não aprendia nada $e$, a professora deixava de castigo depois da aula, tomei mais raiva dela e da matéria”.

“Estes meninos não sabem nada de matemática, nem a tabuada eles decoram".

"Quem inventou essa matéria tão difícil, é o sofrimento dos alunos, desde quando eu estudava até hoje".

"Essa matéria é para os gênios, os cdf, a maioria ficava de recuperação na minha época, a preocupação era a bendita matemática."

Referendamos aos aportes teóricos de Moscovici (2012) e Chartier (2002) e Jodelet (2011) para estes autores as representações sociais sobre a matemática dos alunos principalmente os das séries iniciais do Ensino Fundamental I está intimamente imbricado com a representação social e, ou a imagem dos familiares sobre a matemática. Verifica-se nas respostas colhidas dos pais a representação negativa que tiveram desta disciplina na trajetória escolar e, tais representações são disseminadas no contexto social.

\section{CONCLUSÃO}

Nesta comunicação foi revelada a representação social de 450 alunos do $5^{\circ}$ ano das séries iniciais do Ensino Fundamental I sobre a matemática, no decorrer do trabalho foi evidenciado que as representações sociais têm papel fundamental no processo de ensino e aprendizagem do 
aluno. O estudo apontou que a palavra matemática estava associada a representação social negativa da matemática e, vários adjetivos foram citados para expressar a dificuldade do aluno para aprendizagem dos conteúdos curriculares.

O estudo revelou que a construção da representação social sobre a matemática seja positiva ou negativa está relacionada com a imagem construída individualmente e ou coletivamente, principalmente no ambiente familiar.

Sobre a questão da família o estudo sinalizou correlação entre a representação social sobre a matemática da família com a do filho, visto que os pais revelaram aos filhos que tiveram durante a trajetória escolar experiência negativas sobre a matemática e, vimos que os filhos na maioria das vezes revelaram respostas similares aos pais.

O cotejamento dos dados apontou similaridade deste estudo com outros similares apresentados em eventos científicos da área, principalmente com os dados recentes do Saeb e da Prova Brasil.

Uma das limitações do trabalho foi no momento de explicação com os alunos sobre o significado de representação social, e tal terminologia foi explicada durante toda a etapa da pesquisa.

Os objetivos do estudo foram atingidos ao mapearmos no decorrer do trabalho a representação social dos sujeitos pesquisados e mostrar que as representações sociais negativas prevalecem sobre as positivas e, conforme apontou no estudo as mesmas aumentam em relação ao ano letivo do aluno.

A relevância social deste manuscrito foi trazer à luz a representação social sobre a matemática de 450 alunos do $5^{\circ}$ ano do Ensino Fundamental I, série que de acordo com os indicadores do Ministério da Educação (SAEB) tem revelado que de forma geral $70 \%$ dos alunos brasileiros tem dificuldade de aprendizagem dos conteúdos curriculares de referência nacional de ensino previstos para a matemática. Especificamente no $5^{\circ}$ ano apenas $40 \%$ dos alunos brasileiros estão no nível de aprendizagem adequado.

Aponta-se como contribuição do estudo, apresentar subsídios teóricos e dados numéricos que comprova os dados das avaliações de larga escala sobre os resultados insatisfatórios dos alunos do $5^{\circ}$ ano em matemática

Ainda aponta-se como contribuição para área, revelar que tal resultado divulgado neste estudo e em espectro nacional pelo governo federal tem associação com a representação social do aluno sobre a matemática, tem impacto positivo ou negativo em toda a trajetória do aluno. Sugere-se para futuros estudos a investigação acerca da representação social dos professores de matemática sobre a matemática, porque estes atores educacionais são os principais responsáveis pelo processo de ensino e aprendizagem.

Finaliza-se o estudo apontando que a representação social dos alunos sobre a matemática, disciplina que tem colaborado para o fracasso do aluno na educação básica deve aprofundar nesta investigação teórica, afim de elucidar que os alunos carregam com si suas crenças e representações sobre esta disciplina e o sucesso da aprendizagem está estritamente relacionada da imagem positiva ou negativa construída.

\section{REFERÊNCIAS}

ABRIC, A. Representações sociais em educação. São Paulo. Editora: Vozes, 2001.
ALMEIDA, D.P.G. Representações sociais do ensino de matemática ( Dissertação de Mestrado), UFPE,2011.

ALVES-MAZZOTTI, A.J. Representações sociais: desenvolvimento atuais e aplicações à educação. Rio de Janeiro. Editora: DP\& A, 2002.

BARDIN, L. Análise do conteúdo. São Paulo: Edições 70, 2011.

BICUDO, M.A.V. Filosofia da educação matemática segundo uma perspectiva fenomenológica. São Paulo. Editora: UNESP, 2010. p.23-47.

M.A.V. Filosofia da educação matemática: sua importância na formação de professores de matemática. São Paulo. Editora: Cortez, 2018. p.29-46.

M. A.V. Mathematics education actualized in the cyberspace: a philosophical of mathematics education today. Springer. 2018a. p.253-270.

BRASIL. Sistema Nacional de Avaliação da Educação Básica. Brasília, 2017.

CAMPOS, D.M.S. Psicologia da adolescência. Rio de Janeiro. Editora: Vozes,1996.

CHARTIER, R. O mundo como representação. Rio Grande do Sul, 2002.

D’AMBRÓSIO, U. Educação Matemática: teoria e prática. 2.ed. São Paulo: Papirus, 2012.

DURKHEIM, E. As regras do método sociológico. São Paulo. Editora: Martin Claret, 2001.

ENEM - Encontro Nacional de Educação Matemática, 2018.

FIORENTINI, D.; LORENZATO,S. Investigação em educação matemática. 2.d. São Paulo. Editora: Autores Associados, 2012.

JODELET, D. Representações sociais: aspectos teóricos e aplicações à educação. Múltiplas Letras. n.1, v.1, p. 1843,2011.

JULIA, D. A cultura escolar como objeto histórico. Revista Brasileira de História da Educação. v.1, n.01, p. 9-44, 2001.

LIMA, C.V.B. Representações sociais da escola em produções de alunos do ensino fundamental. (Dissertação de Mestrado) Universidade Estadual de Campinas, 2014.

HUSSERL, E. O que é fenomenologia. Paris, 2007.

MACHADO, L.B.; CORDEIRO, V. As representações sociais de formação na licenciatura de estudantes de pedagogia. Revista Educação. v.40, n.1, p. 79-100, 2015.

MINAYO,C.M.C.S. O conceito de representações sociais dentro da sociologia clássica. 2.ed. Rio de Janeiro, 1995.

MOSCOVICI, S. A Teoria das representações sociais. São Paulo: Atlas, 2013.

Representações sociais: investigações em psicologia social. 10. Ed. Rio de Janeiro. Editora: Vozes, 2012.

1961.
A teoria da representação social. Paris, 
NÓVOA, A. Professores imagens do futuro e presente. Lisboa: Educa, 2009.

PEREIRA,C.L; HILÁRIO,J. A matemática do curso de pedagogia. Revista Sodebras. n.1, v.1. p.13-19, 2015.

PISA. Programa Internacional de Avaliação de Alunos. 2015.

SILVA, R.D.; SILVA, V.V.M. As representações matemáticas dos alunos do ensino fundamental. Paraná, 2013.

TRIVINÕS, A.N.S. Introdução à pesquisa em ciências sociais: a pesquisa qualitativa em educação - o positivismo, a fenomenologia, e o maxismo. 2.ed. São Paulo. Editora: Atlas, 2017.

UJIIE, N.T. et al. Os conhecimentos prévios de matemática de estudantes do ensino fundamental: o que é matemática? De onde ela veio? Como seria o mundo sem a matemática. Revista de Educação em Ciência e Tecnologia. Florianópolis. v.10, n.01, p.02-17, 2017.

WOLSKI, D.T.R.M. Representações sociais dos alunos sobre diferentes espaços de formação em cursos de licenciatura em matemática. (Tese de Doutorado) Universidade Estadual de Ponta Grossa, 2017.

\section{COPYRIGHT}

Direitos autorais: Os autores são os únicos responsáveis pelo material incluído no artigo.

Submetido em: 07/01/2019

Aprovado em: 15/01/2019 


\section{Área: Ciências Agrárias e Biológicas}

\begin{tabular}{|c|l|}
\hline $5-2$ & $\begin{array}{l}\text { CONDIÇÕES DE BALNEABILIDADE NA ZONA COSTEIRA DO ESTADO DO } \\
\text { PARÁ-BRASIL }\end{array}$ \\
& CONDITIONS OF BATHING IN THE COASTAL ZONE OF THE STATE OF PARÁ- \\
& BRAZIL \\
& Hebe Morganne Campos Ribeiro; Vítor Abner Borges Dutra; Danielle Nazaré \\
& Salgado Mamede Pantoja; Gleice Dos Santos Cabral; Nailda Gomes Pantoja \\
\hline $5-7$ & $\begin{array}{l}\text { USO DE EMBALAGENS ATIVAS PARA CONSERVAÇÃO E AUMENTO DA VIDA } \\
\text { DE PRATELEIRA DE PRODUTOS ALIMENTíCIOS: UMA BREVE } \\
\text { REVISÃO }\end{array}$ \\
& $\begin{array}{l}\text { USE OF ACTIVE PACKAGING FOR THE CONSERVATION AND INCREASE OF } \\
\text { SHELF LIFE OF FOOD PRODUCTS: A BRIEF REVIEW } \\
\text { langla Araújo De Melo Damasceno; Maykon Jhuly Martins De Paiva }\end{array}$ \\
\hline
\end{tabular}




\title{
Revista SODEBRAS - Volume 14 \\ $\mathrm{N}^{\circ} 158$ - FEVEREIRO/ 2019
}

\section{CONDIÇÕES DE BALNEABILIDADE NA ZONA COSTEIRA DO ESTADO DO PARÁ-BRASIL}

\author{
CONDITIONS OF BATHING IN THE COASTAL ZONE OF THE STATE OF \\ PARÁ-BRAZIL
}

\author{
HEBE MORGANNE CAMPOS RIBEIRO ${ }^{1}$ VÍTOR ABNER BORGES DUTRA ${ }^{1}$, DANIELLE NAZARÉ \\ SALGADO MAMEDE PANTOJA ${ }^{2}$, GLEICE DOS SANTOS CABRAL ${ }^{2}$, NAILDA GOMES PANTOJA ${ }^{2}$ \\ 1 - UNIVERSIDADE DO ESTADO DO PARÁ (UEPA); 2 - LABORATÓRIO CENTRAL DO \\ ESTADO DO PARÁ (LACEN-PA) \\ hebemcr@gmail.com
}

\begin{abstract}
Resumo - Este estudo objetivou avaliar a balneabilidade de extensas zonas litorâneas com potencial turístico do estado do Pará-Brasil nos anos de 2016 e 2017 a partir das diretrizes estabelecidas pela Resolução CONAMA $n^{\circ}$ 274/2000. A análise dos resultados demonstrou desconformidade das condições mínimas de balneabilidade das praias do município de Salinas, como Corvina, Atalaia e Farol Velho e o Lago da Coca Cola. A partir dessa análise, tornou-se evidente a necessidade da implantação de um programa urgente de monitoramento da qualidade da água, e que este seja feito durante o ano inteiro $e$ intensificado próximo à época de maior incidência de público, ou seja, nas férias do meio e no fim do ano.
\end{abstract}

Keywords: Escherichia Coli. Enterococos. Praias da Amazônia.

\begin{abstract}
This study aimed to evaluate the bathing of large coastal areas with tourist potential in the state of Pará-Brazil in the years 2016 and 2017, based on the guidelines established by CONAMA Resolution No. 274/2000. The analysis of the results showed that the minimum bathing conditions of the beaches of the municipality of Salinas, such as Corvina, Atalaia and Farol Velho and Coca Cola Lake, were inconsistent. From this analysis, it became clear that an urgent water quality monitoring program needs to be implemented, and that this should be done during the whole year and intensified near the time of the highest incidence of public, i.e., during middle and the end of the year.
\end{abstract}

Keywords: Escherichia Coli. Enterococci. Amazon Beaches.

\section{INTRODUÇÃO}

Comunidades de zonas costeiras são economicamente dependentes do turismo. Em vista disso, nessas zonas devem haver padrões de monitoramento da qualidade da água para atividades com fins de recreação (BUER et al., 2018). Por conseguinte, a balneabilidade é entendida como a qualidade dos corpos d'água para a recreação de contato primário, isto é, um contado direto e prolongado com a água, onde a possibilidade de ingerir quantidades apreciáveis desta é elevada.

Desde meados do século XX estudos já apontavam a possibilidade das águas utilizadas para lazer apresentarem efeitos danosos à saúde humana, ou seja, o contato direto com os recursos hídricos para recreação pode levar à exposição a microrganismos patogênicos, eventualmente presentes nesse ambiente (WADE et al., 2010).
Tradicionalmente, a avaliação das condições de balneabilidade é feita pelo monitoramento da concentração de microrganismos indicadores fecais na água, pois estes apresentam correlação com doenças de veiculação hídrica (VON SPERLING, 2014).

A Agência de Proteção Ambiental Norte Americana definiu sua primeira diretriz para balneabilidade em 1986, utilizando Enterococos e Escherichia coli como principais indicadores bacteriológicos em águas para fins de recreação (EPA, 1986). Por outro lado, os critérios de balneabilidade em águas brasileiras foram efetivados somente no século XXI, através da Resolução $n^{\circ} 274$, de 29 de novembro de 2000, do Conselho Nacional do Meio Ambiente (BRASIL, 2000).

No Brasil, os critérios de Escherichia coli e Enterococos devem ser utilizados tanto em praias litorâneas quanto em águas interiores. Além disso, há o estabelecimento de critérios, baseados em padrões de contaminação, que visam identificar as condições das águas para fins de recreação em um determinado local (BRASIL, 2000).

A cidade de Belém, capital do Estado do Pará, é o ponto de partida para os turistas conhecerem a Costa Atlântica. Na Zona do Salgado encontram-se praias oceânicas, como as de Salinas, Marudá, Bragança dentre outras.

Um dos balneários mais procurados nas férias localizase no município de Salinópolis. Salinas, como é popularmente conhecida, possui $217,856 \mathrm{~km}^{2}$, está situada na Amazônia Atlântica no litoral nordeste do Pará, fazendo parte da microrregião geográfica do Salgado. Encontra-se na latitude $00^{\circ} 36^{\prime} 49^{\prime \prime}$ sul e longitude $47^{\circ} 21^{\prime} 22^{\prime \prime}$ oeste, estando a uma altitude de $21 \mathrm{~m}$, distante cerca de $220 \mathrm{~km}$ de Belém (IBGE, 2018).

O município de Salinópolis tem população estimada de 37.430 habitantes, economia centrada na pesca e, sobretudo, na atividade turística e apresenta Índice de Desenvolvimento Humano de 0,74 (IBGE, 2018). A paisagem é formada por praias, rios, igarapés, mangues, furos e dunas. As praias são compostas por areias finas e brancas, com águas de tonalidade verde-acinzentada, devido aos sedimentos carregados pelas águas do Rio Amazonas (IBGE, 2018). 
A cidade de Salinópolis possui vários pontos turísticos, como as praias da Corvina e do Atalaia (a mais movimentada). Esta última localiza-se $13 \mathrm{~km}$ da cidade, possui águas limpas e cristalinas, areias finas, dunas e pequenos lagos (a exemplo do Lago da Coca-Cola). Próxima ao Atalaia está a praia do Farol Velho, e juntas ambas se estendem por cerca de $20 \mathrm{~km}$ de extensão (SILVA, 2018).

Outro local com extensiva atividade turística é Marapanim, tendo como sede a cidade homônima. O município encontra-se em latitude $00^{\circ} 43^{\prime} 03$ ' sul e longitude 47 41'59" oeste, com altitude de $40 \mathrm{~m}$. Sua população estimada em 2016 era de 27.471 habitantes. Além disso, possui área total de $799,299 \mathrm{~km}^{2}$ e suas praias mais famosas são as do Crispim e Marudá (IBGE, 2018).

Mais praias com extensiva atividade turística encontram-se no município de Barcarena-PA. Tal município limita-se ao Norte com a Baía de Guajará e Município de Belém, ao Sul com os Municípios de Moju e Abaetetuba, a Leste com a Baía de Guajará e Município de Acará e a Oeste com a Baía do Marajó. Localizam-se neste município as praias do Caripi, de Vila do Conde e de Itupanema (RIBEIRO, 2014).

Um outro município que merece destaque para balneabilidade é Abaetetuba. Pertencente à Microrregião de Cametá, localiza-se a uma latitude $01^{\circ} 43^{\prime} 05^{\prime}$ ' sul e longitude 48 52'57" oeste, às margens do Rio Maratauíra (afluente do Rio Tocantins). Abaetetuba é formada por dois distritos: Abaetetuba (sede) e a Vila de Beja. O município possui uma rede hidrográfica vasta, navegável em quase toda sua extensão. Além disso, existem cerca de 72 ilhas que constituem a denominada Região das Ilhas. O clima é comum da Amazônia, equatorial e super-úmido. Apresenta a Praia de Beja, um balneário localizado a $22 \mathrm{~km}$ do município de Abaetetuba e conta com uma praia banhada pelas águas do rio Pará (IBGE, 2018).

Nesse contexto de extensas zonas litorâneas com potencial turístico, o presente estudo objetivou avaliar a balneabilidade e o risco de infecção para banhistas nos anos de 2016 e 2017 em diferentes praias de diversos distritos e municípios paraenses, a partir das diretrizes estabelecidas pela Resolução CONAMA n 274/2000.

\section{METODOLOGIA}

\section{1 - Área de estudo}

O estudo foi realizado no período de 2016 a 2017, em diferentes ciclos de marés (baixa-mar e preamar) nas águas dos balneários nos seguintes distritos e municípios:

1 - Distrito de Icoaraci: Praia do Cruzeiro;

2 - Distrito de Outeiro: Praia do Amor, Praia Grande, Praia Brasília;

3 - Distrito de Mosqueiro: Praia Baía do Sol, Praia do Paraíso, Praia de Marahú, Praia de São Francisco, Praia do Ariramba, Praia do Murubira, Praia do Chapéu Virado, Praia do Farol, Praia Grande e Praia do Areão;

4 - Município de Barcarena: Praia de Conde, Praia do Caripi, Praia de Itupanema;

5 - Município de Marapanim: Praia de Marudá, Praia do Crispim e Praia de Marapanim;

6 - Município de Salinas: Lago da Coca-cola, Praia da Corvina, Praia do Atalaia, Praia do Foral Velho;

7 - Município de Bragança: Praia de Ajuruteua; e

8 - Município de Abaetetuba: Praia de Beja.

\section{2 - Análise de dados}

A amostragem foi realizada de acordo com as normas da Associação Brasileira de Normas Técnicas e da Companhia Ambiental do Estado de São Paulo - CETESB. Cada coleta foi realizada aproximadamente cumprindo-se a isóbata de $1 \mathrm{~m}$ de profundidade e nos pontos de maior concentração de banhistas, conforme Resolução CONAMA $\mathrm{n}^{\circ} 274$, de 29 de novembro de 2000, com sacos coletores estéreis de $500 \mathrm{ml}$ de capacidade para análises microbiológicas e físico-química $(\mathrm{pH})$.

As amostras foram transportadas para o Laboratório Central do Estado do Pará (LACEN-PA) em caixa isotérmica contendo gelo reciclado para evitar o contato direto com a amostra, e assim mantido refrigerado até o momento da análise.

Para quantificação de Enterococos e Escherichia coli, foi empregado o Colilert, que utiliza tecnologia de substrato enzimático definido e é aceito pelos métodos padrões para exames de água e esgoto, segundo Standard Methods for the Examination of Water and Wastewater, 23rd Edition (2017).

A classificação dos corpos hídricos em águas doces, salobras ou salinas, bem como os valores de referência adotados para os padrões microbiológicos e $\mathrm{pH}$ seguiram aos critérios da Resolução CONAMA n 274, de 29 de novembro de 2000.

A montagem dos diagramas quantitativos foi pormenorizada em planilha eletrônica, tipologia open spreadsheet XML da plataforma Microsoft Excel 2010 e uso da função 2-D Clustered Column.

\section{3 - Enquadramento na Resolução CONAMA n ${ }^{\circ}$ 247/2000}

A Resolução do CONAMA n ${ }^{\circ} 274$, de 29 de novembro de 2000 , no seu artigo $2^{\circ}$ preconiza que as águas doces, salobras e salinas destinadas à balneabilidade (recreação de contato primário) terão sua condição avaliada nas categorias própria e imprópria.

As águas consideradas próprias são subdivididas nas seguintes categorias (BRASIL, 2000):

a) Excelente: quando em $80 \%$ ou mais de um conjunto de amostras colhidas no mesmo local, houver, no máximo, 200 Escherichia coli ou 25 enterococos por 100 mililitros;

b) Muito boa: quando em $80 \%$ ou mais de um conjunto de amostras colhidas no mesmo local, houver, no máximo, 400 Escherichia coli ou 50 enterococos por 100 mililitros; e

c) Satisfatória: quando em $80 \%$ ou mais de um conjunto de amostras colhidas no mesmo local, houver, no máximo, 800 Escherichia coli ou 100 enterococos por 100 mililitros.

Além das condições supracitadas, ressalta-se que para as águas marinhas, os padrões devem referir-se aos enterococos.

As águas serão consideradas impróprias quando no trecho avaliado, for verificada pelo menos uma das seguintes situações (BRASIL, 2000):

a) o não atendimento as águas próprias;

b) quando o valor obtido na última amostragem for superior a 2000 Escherichia coli ou 400 enterococos por 100 mililitros, este foi o valor de referência utilizado para condução do laudo em satisfatório ou não. 
c) quando houver incidência elevada ou anormal, na região, de enfermidades transmissíveis por via hídrica, indicada pelas autoridades sanitárias; e

d) quando houver presença de resíduos ou despejos, sólidos ou líquidos, inclusive esgotos sanitários, óleos, graxas e outras substâncias, capazes de oferecer risco à saúde ou tornar desagradável à recreação.

O parâmetro pH deve ficar entre 6,0 e 9,0 para águas doces, à exceção das condições naturais.

\section{RESULTADOS E DISCUSSÕES}

Os resultados das análises microbiológicas e do $\mathrm{pH}$, bem como os limites definidos pelo CONAMA $n^{\circ}$ 274/2000 para corpos d'agua para fins de balneabilidade estão apresentados nas Figuras 1 a 4.

Figura 1 - Resultados analíticos de Escherichia coli de praias paraenses em 2016

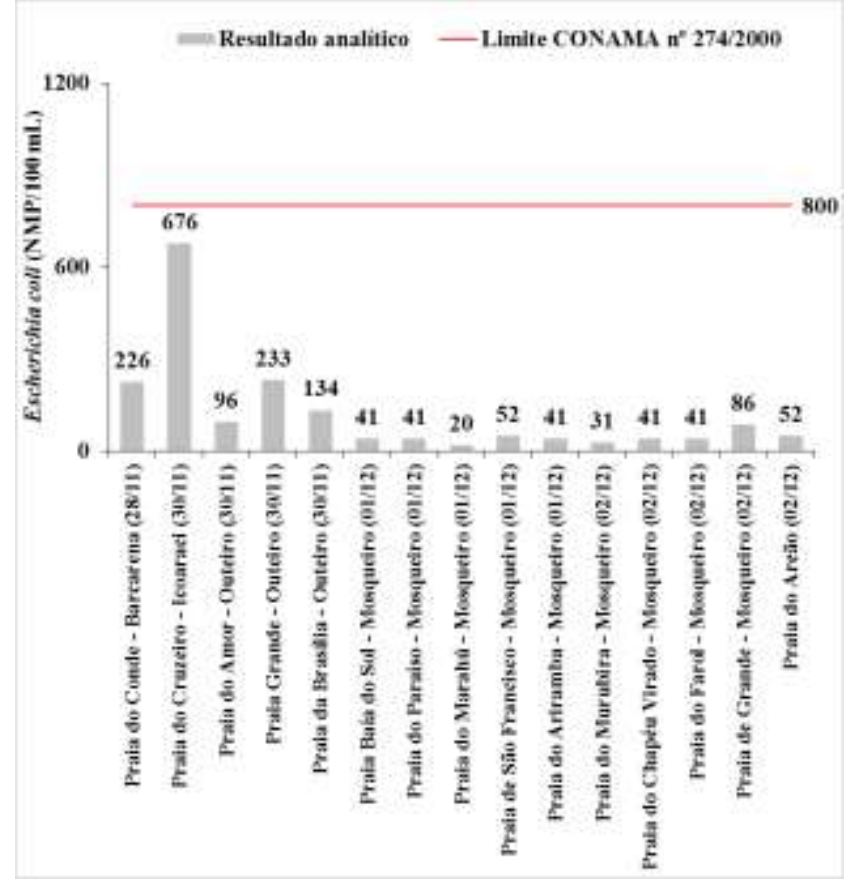

Fonte: LACEN (2016).
Figura 2 - Resultados analíticos de pH de praias paraenses em 2016

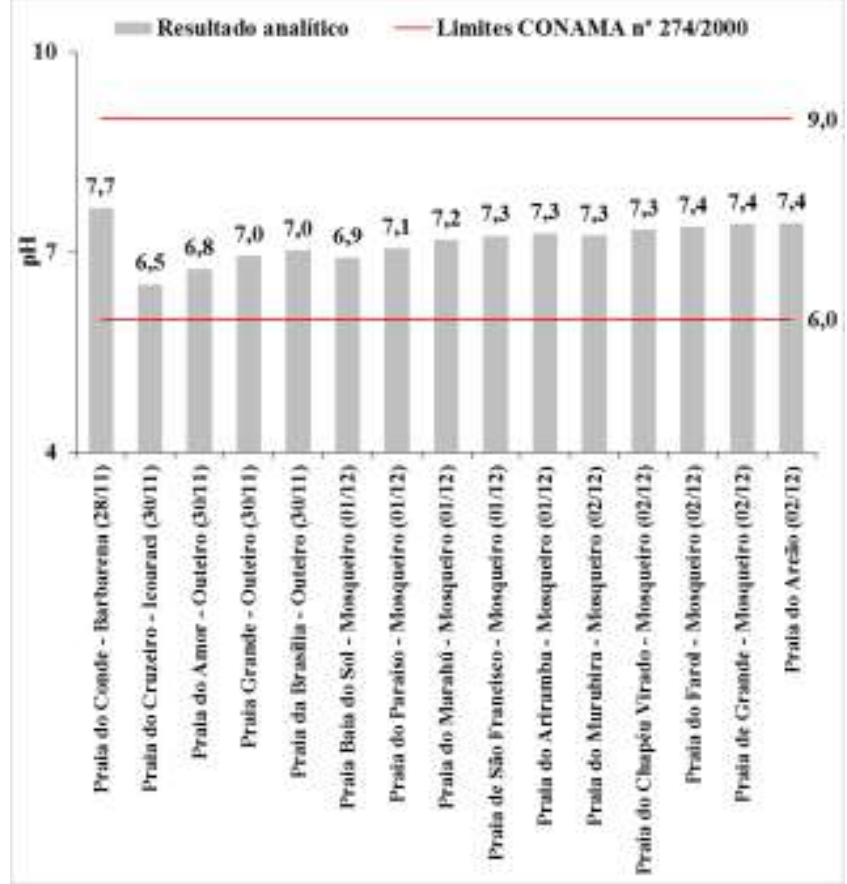

Fonte: LACEN (2016).

Figura 3 - Resultados analíticos de Escherichia coli e enterococos de praias paraenses em 2017

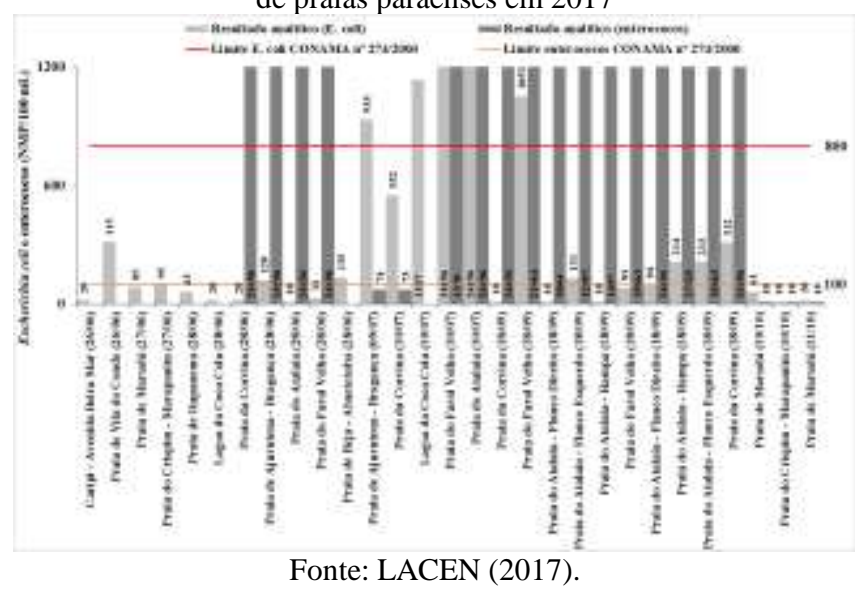

Figura 4 - Resultados analíticos de pH de praias paraenses em 2017

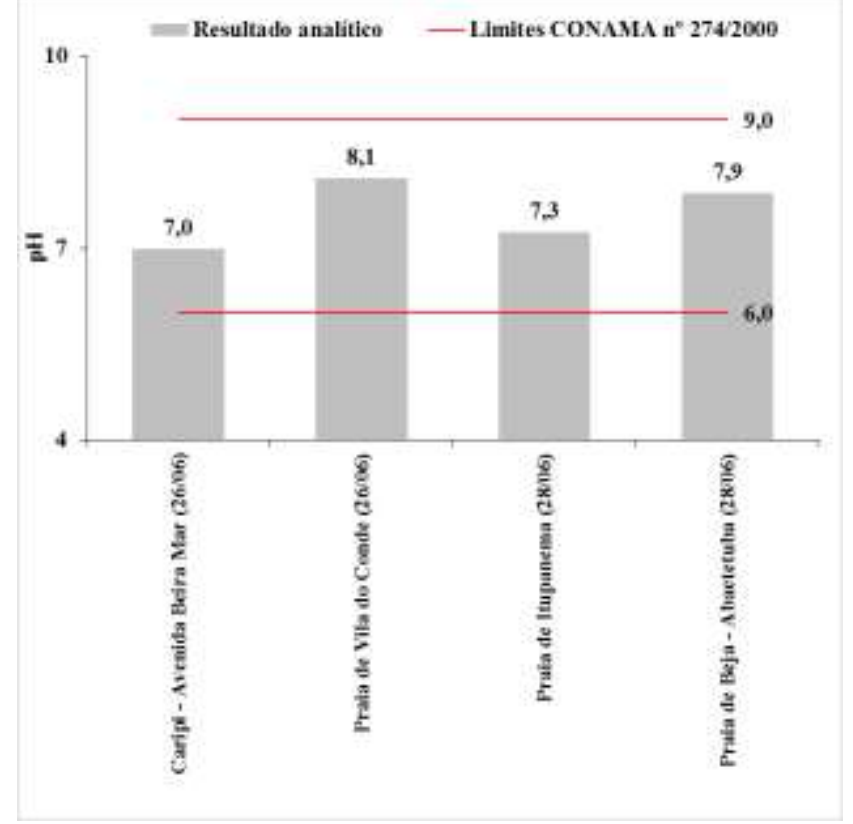

Fonte: LACEN (2017). 
Os principais indicadores de contaminação fecais comumente utilizados em águas são: coliformes totais (CT), coliformes fecais (CF), preferencialmente denominados de coliformes termotolerantes, Escherichia coli (EC) e nos padrões referentes às águas marinhas, aplicam-se os Enterococos (BRASIL, 2000; VON SPERLING, 2014).

A detecção dos agentes patogênicos em uma amostra d'água é deveras ímproba, em função das suas baixas concentrações. Tal assertiva é ratificada pela avantajada demanda de exames amostrais para detectação de poucos microrganismos patogênicos. Isto posto, os seres mais ordinariamente utilizados com tal finalidade são as bactérias do grupo coliforme (VON SPERLING, 2014).

O grupo de coliformes totais fora bastante empregado enquanto indicador, e continua a ser usado em algumas áreas científicas, a despeito das adversidades associadas com a ocorrência de bactérias não fecais. Não há uma relação quantificável entre CT e microrganismos patogênicos. Os coliformes totais são analogamente dados como "coliformes ambientais", vista sua possível incidência em águas e solos não contaminados, representando, portanto, outros organismos de vida livre. Por este pressuposto, os coliformes totais não devem ser utilizados como indicadores de contaminação fecal em águas superficiais.

Os coliformes termotolerantes são de um grupo indicadores de organismos originários predominantemente do trato intestinal humano e outros animais, compreende o gênero Escherichia e, em menor graus, espécies de Klebsiella, Enterobacter e Citrobacter (WHO, 1993). A Escherichia coli é a principal bactéria do grupo de coliformes termotolerantes, sendo abundantes nas fezes humanas e de animais de sangue quente. Diferentemente dos coliformes totais e fecais, Escherichia coli é a única que dá garantia de contaminação exclusivamente fecal. No entanto não dá garantia que seja de contaminação humana, o que não invalida seu conceito como bactérias indicadoras de contaminação fecal.

O Estreptococcus fecais compreende dois gêneros principais: Enterococcus e Streptocccus. O gênero Enterococcus possui várias espécies, a maioria das quais de origem fecal humana, embora algumas sejam também de origem animal, apresentam alta tolerância a condições ambientais adversas e são mais resistentes do que Escherichia coli e bactérias do grupo.

Desta forma, a partir dos resultados analíticos para Escherichia coli nas dezesseis praias de água doce analisadas no ano de 2016 como demonstrado na Figura 1, pôde-se verificar que, dez praias na Ilha de Mosqueiro (Baía do sol, Paraíso, Marahú, São Francisco, Ariramba, Murubira, Chapéu virado, Farol , Praia Grande e Areão) e duas na Ilha de Outeiro (Brasília e Amor), encontraramse próprias para balneabilidade, dentro da categoria excelente; uma outra praia na Ilha de outeiro, também encontraram-se próprias (Praia Grande) dentro da categoria Muito Boa, assim como uma de Barcarena (do Conde); uma em Icoaraci foi considerada satisfatória com valores elevados de coliformes termotolerantes, 676 $\mathrm{NMP} / 100 \mathrm{~mL}$.

Os resultados das análises bacteriológicas em vinte nove análises de balneabilidade entre praias de águas doces, um lago (Escherichia coli) e praias de águas salgadas (Enterococos) no ano de 2017, como demonstrado na Figura 3, verificou-se que as praias de águas doces (Caripi, de Beja e Itupanema), foram consideradas próprias na categoria Excelente, já a praia de Vila do Conde foi considerada própria na categoria Muito Boa. As praias com influência oceânica como as do município de Salinas tiveram suas águas consideradas impróprias, a saber: Lago da Coca Cola, praias (da Corvina, do Atalaia e do Farol Velho); Bragança (Ajuruteua) com valores acima do estabelecido na legislação para Enterococos.

Por outro lado, às praias dos municípios de Bragança, Marudá e do Crispim tiveram suas águas consideradas próprias, na categoria excelente.

As análises de $\mathrm{pH}$ para balneabilidade foram medidas no LACEN, somente nos balneários de água doce como estabelecido pela resolução e todas encontraram-se dentro da variação estabelecida, como pode ser observado nos gráficos 2 e 4 .

\section{CONCLUSÕES}

Em vista dos resultados encontrados quanto a balneabilidade no estado do Pará, conclui-se que as praias do município de Salinas - Corvina, Atalaia e Farol Velho - e o Lago da Coca Cola demonstraram inconformidade com a Resolução CONAMA $n^{\circ}$ 274/2000, ou seja, foram impróprias para recreação de contato primário durante período estudado.

No contexto da gestão pública, expõe-se a necessidade de implementação de um programa de monitoramento hídrico urgente nos locais retrocitados. Tal programa deve ser realizado durante o ano inteiro (para melhor compreensão da sazonalidade da região costeira), com especial atenção para sua intensificação próximo à época de maior incidência de público, ou seja, nas férias de meio e fim de ano.

\section{AGRADECIMENTOS}

Os autores agradecem a disponibilização dos dados do LACEN-PA.

\section{REFERÊNCIAS}

BRASIL. Resolução no 274 , de 29 de novembro de 2000 - Define os critérios de balneabilidade e águas brasileiras. Brasília: Conselho Nacional do Meio Ambiente, 2000.

BUER, A. L. et al. Long term development of Bathing Water Quality at the German Baltic coast: spatial patterns, problems and model simulations. Marine Pollution Bulletin, v. 135, p. 1055-1066, 2018.

EPA. Quality Criteria for Water. Washington, D.C.: United States Environmental Protection Agency, 1986.

IBGE. IBGE Cidades. Disponível em: $<$ https://cidades.ibge.gov.br/>.

VON SPERLING, M. Introdução à qualidade das águas e ao tratamento de esgotos. 4. ed. Belo Horizonte: UFMG, 2014.

WADE, T. J. et al. Rapidly measured indicators of recreational water quality and swimming-associated 
illness at marine beaches: A prospective cohort study. Environmental Health: A Global Access Science Source, v. 9, n. 1, p. 1-14, 2010.

\section{COPYRIGHT}

Direitos autorais: Os autores são os únicos responsáveis pelo material incluído no artigo.

Submetido em: 17/12/2018

Aprovado em: 03/02/2019 


\author{
Revista SODEBRAS - Volume 14 \\ $\mathrm{N}^{\circ} 158$ - FEVEREIRO/ 2019
}

\title{
USO DE EMBALAGENS ATIVAS PARA CONSERVAČ̃̃O E AUMENTO DA VIDA DE PRATELEIRA DE PRODUTOS ALIMENTÍ́CIOS: UMA BREVE REVISÃO
}

\author{
USE OF ACTIVE PACKAGING FOR THE CONSERVATION AND INCREASE OF \\ SHELF LIFE OF FOOD PRODUCTS: A BRIEF REVIEW
}

\author{
IANGLA ARAÚJO DE MELO DAMASCENO'; MAYKON JHULY MARTINS DE PAIVA ${ }^{2}$ \\ 1 - CENTRO UNIVERSITÁRIO PRESIDENTE ANTÔNIO CARLOS; 2 - UNIVERSIDADE FEDERAL DO \\ TOCANTINS \\ iangla@hotmail.com; maykonjhuly@hotmail.com
}

\begin{abstract}
Resumo - Os consumidores e os próprios órgãos de saúde pública, especialmente preocupados com os efeitos da utilização de vários aditivos químicos em produtos alimentares estimularam o desenvolvimento de novas alternativas. Este cenário encorajou a investigação de agentes naturais que podem ser utilizados de forma a complementar os métodos de preservação de alimentos atualmente disponiveis. $O$ objetivo do trabalho foi realizar uma revisão da literatura sobre o uso de embalagens ativas, relacionadas à incorporação de óleo essencial, de plantas que apresentem atividade antimicrobiana em filmes de diferentes materiais. Foi possível observar que existem muitas mudanças na aplicação das metodologias e estão ligadas ao alimento usado e a finalidade do filme que vai ser utilizado. Com importantes resultados notou-se que os filmes têm ação inibitória a microorganismos efetiva e a diversidade de filmes e óleos é vasta podendo em sua maioria ser utilizados em escala industrial.
\end{abstract}

Palavras-chave: Embalagens Ativas. Óleo Essencial. Atividade Antimicrobiana.

Abstract-Consumers and public health bodies themselves, particularly concerned about the effects of using various chemical additives in food products, have stimulated the development of new alternatives. This scenario encouraged the investigation of natural agents that can be used to complement existing food preservation methods. The objective of this work was to review the literature on the use of active packaging, related to the incorporation of essential oil, of plants that present antimicrobial activity in films of different materials. It was possible to observe that there are many changes in the application of methodologies and are linked to the food used and the purpose of the film that will be used. With important results it was noticed that the films have effective inhibitory action to the microorganisms and the diversity of films and oils is vast being able to be mostly used on an industrial

Keywords: Active Packaging. Essential Oil. Antimicrobial Activity.

\section{INTRODUÇÃO}

O consumidor tem buscado opções de alimentos mais saudáveis minimamente processados e livres de agrotóxicos. Essa demanda tem contribuído para o advento de novas tecnologias que busquem proteger o alimento de uma contaminação extrínseca ou limitar uma deterioração promovida por fatores intrínsecos (FARIA, et al., 2017).
Na tentativa de melhorar a qualidade dos alimentos, os pesquisadores têm voltado às atenções para o desenvolvimento de embalagens mais seguras. $\mathrm{O}$ uso de embalagens para conservar e manter o alimento íntegro consiste no conceito de embalagem passiva, cuja função está relacionada ao marketing do produto e a sua proteção pósembale. Diferentemente do uso convencional, temos a embalagem ativa, que modifica as condições do produto embalado, com a finalidade de manter a qualidade pósembale e aumentar avida de prateleira (FIALHO \& MORAES et al., 2011).

A função das embalagens de alimentos evoluiu ao longo dos anos, de simples preservação, para incluir aspectos como marketing e segurança ambiental. As embalagens ativas de alimentos são um bom exemplo de inovação que vai além das funções tradicionais da embalagem, pois propõe a interação da embalagem com a o alimento a fim de estender a vida de prateleira e melhorar a sua segurança ou propriedades sensoriais (REALINI; MARCOS, 2014).

Uma das possíveis aplicações das embalagens ativas é a liberação de compostos antimicrobianos que aumentam a vida de prateleira. Assim, de acordo com a característica do material filmogênico e da substância incorporada temos, filmes com diferentes características, destacando-se: função aromatizante, antimicrobiana, antioxidante, entre outras. (COZMUTA, et al., 2017).

No presente trabalho, o enfoque foi dado à atividade antimicrobiana da embalagem ativa como a incorporação de óleo essencial de plantas que apresentem alguma atividade antimicrobiana em filmes de diferentes materiais. A finalidade é reduzir a taxa de crescimento microbiano, estender a fase lag ou inativar os microrganismos por meio do contato com agente antimicrobiano (FIALHO \& MORAES et al., 2011; SALARBASHI et al., 2014; BRADELERO, et al., 2015).

Diante do exposto, a pesquisa tem como objetivo relatar o uso de embalagens ativas, incorporado ao uso de óleo essencial relacionado a plantas que apresentem atividade antimicrobiana de diferentes origens, verificando anda se o uso de tais embalagens tem apresentado resultados significativos em relação ao aumento da vida de prateleira dos produtos testados. 


\section{METODOLOGIA}

Foram realizadas pesquisas nas seguintes bases de dados eletrônicas: Web of Science, SciELO, PubMed, Lilacs, Science Direct e periódicos CAPES. Os descritores utilizados foram:

"activepackaging", "activepackagingoilessential”, "activepa ckagingandshelflife" "antimicrobialactivepackaging". Os critérios de inclusão foram: artigos publicados entre 2010 e 2018 sobre a incorporação de algum tipo de óleo essencial em filmes, biodegradáveis ou não, para uso como embalagem ativa, com atividade antimicrobiana e artigos clássicos do assunto.

Os critérios de exclusão adotados para esta revisão foram: artigos que apresentaram o uso de embalagens ativas associadas a outras tecnologias, como atmosfera modificada, nanotecnologia, entre outros.

\section{RESULTADOS}

\section{1 - Embalagem Ativa}

A abordagem dos artigos mostra a diversidade de materiais que podem ser utilizados como base para embalagens ativas e agentes antimicrobianos que podem ser incorporados nesses filmes.

Durante muito tempo a indústria buscou embalagens com características que permitiam a não interação com o produto embalado, hoje com conceito de embalagem ativa, o que se pretende é justamente o contrário, a interação da embalagem com o produto e que a mesma contribua para a melhoria das características sensoriais e aumento da vida de prateleira do embalado (APPENDINIA; HOTCHKISSB, 2012).

De acordo com Singh et al. (2011), o conceito de embalagem ativa para alimentos é bastante complexo e envolve uma variedade de possibilidades que podem ser classificadas quanto a finalidade sob dois aspectos, (1) para estender a vida de prateleira; e (2) para facilitar o processamento e consumo de alimentos.

Os artigos selecionados neste trabalho dizem respeito às características antimicrobianas de óleos essenciais incorporados em filmes, e sob esse aspecto atendem ao primeiro requisito que visa estender a vida de prateleira dos produtos embalados (FARIA, et al., 2017).

Entre as embalagens ativas podemos citar e diferenciar dois conceitos: os filmes, películas finas, produzidas e posteriormente aplicadas para envolver o produto, ou para separá-lo em camadas; e os revestimentos, formados diretamente sobre a superfície do produto que se pretende proteger (BASTOS et al., 2013).

Alguns polímeros como polietileno (PE) podem ser utilizados, porém, compostos biodegradáveis como quitosana, tem merecido destaque, e os estudos recentes concentram-se na incorporação de substâncias antimicrobianas em biofilmes e que os mesmos, possam ser utilizados como embalagens em produtos prontos para consumo, e/ou minimamente processados.

Foi possível observar também que foram usadas diferentes fontes poliméricas para obtenção dos filmes. Os polissacarídeos foram as matrizes com maior frequência de utilização, o que sugere muito a sua alta disponibilidade na natureza e boas propriedades para formação dos filmes em várias partes de todo o mundo (CAZÓN et al., 2016).

\section{2 - Óleo Essencial e Embalagem ativa}

O Quadro 1 mostra trabalhos utilizando aldeído cinâmico (LOPES et al., 2014); orégano; (EMIROĞLU et al., 2010), cravo (GÓMEZ-ESTACA et al., 2010), com atividades comprovadas contra diferentes espécies de fungos e bactérias. O trabalho realizado por Mehdizadeh et al. (2012) demonstrou a utilização de óleo essencial de Thymuskotschyanus, uma planta da família do tomilho, amplamente cultivada nos países do Oriente. O Oléo Essencial (OE) e Thymuskotschyanus, foi incorporado ao filme de quitosana e apresentou resultados significativos, inibiu o crescimento de L. monocytogenes, E. coli $\mathrm{O} 157: \mathrm{H} 7$, S. aureus e $S$. typhimurium, microrganismos importantes na deterioração dos alimentos e responsáveis por surtos alimentares.

OE de canela foi testado nos trabalho de Manso et al. (2014) em filmes de Polipropileno para inibir o crescimento de Aspergillus flavus, por Bahramet al. (2014) em filme proteico de soro de leite contra bactérias e fungos e por Ojagh et al. (2010) em filmes de quitosana contra bactérias como L. monocytogenes, responsável por diversos surtos alimentares e que representam um risco a saúde do consumidor.

O mesmo óleo essencial pode ser testado em diferentes filmes e para inibir o crescimento de microrganismos diferentes, o que determina essa escolha é o alimento que se pretende avaliar (CARDOSO, et al., 2017).

\section{3 - Embalagem Ativa Antimicrobiana}

Segundo Appendinia e Hotchkissb (2012), o contato da embalagem ativa com o produto embalado é condição precípua para o controle microbiano, pois é sobre a superfície do alimento que boa parte dos micro-organismos responsáveis pela deterioração dos alimentos está localizada.

De acordo com o Quadro 1 podemos observar a diversidade de óleos essenciais e materiais utilizados na incorporação dos mesmos, bem como o alvo da atividade antimicrobiana abrange fungos e/ou bactérias.

Sanchez-Gonzalez et al. (2010), testaram o uso de embalagens ativas sobre fungos com OE de bergamota contra Penicillium italicume Souza et al.(2013)filme de amido de mandioca incorporado com OE de canela, para inibir o crescimento de $P$. communee $E$. amstelodami, fungos que comumente estão associados a deterioração de produtos de panificação.

Botre et al. (2010)demonstrou que filmes de base celulósica e óleo essencial de orégano são eficientes na diminuição de Penicilium spp., e a aplicação de orégano em pó e foi possível observar que o filme não compromete a avaliação sensorial do produto, visto que o orégano já e ingrediente da pizza.

Pesquisas com bactérias também são o foco dos estudos com embalagens ativas. Estudo conduzido por Salarbashi $e t$ al. (2014) demonstra o uso de um filme a base de polissacarídeo da soja, incorporados com óleo essencial de Zataria multiflora Boiss (ZEO) e Menthapulegium (MEO). O filme foi testado contra as bactérias: Staphylococcus aureus, Bacilluscereus, Escherichia coli O157:H7, Pseudomonasaeruginosae Salmonellatyphimurium. Os resultados mostraram que os filmes incorporados com ZEO foram mais eficazes na diminuição do crescimento dos microrganismos que os filmes com MEO, sendo S. aureus para ambos os óleos testados. 
Quadro 1 - Características dos filmes e o óleo essencial incorporado para controle microbiano

\begin{tabular}{|c|c|c|c|c|}
\hline $\begin{array}{l}\text { Material do } \\
\text { filme }\end{array}$ & $\begin{array}{l}\text { Óleo Essencial ou } \\
\text { isolado }\end{array}$ & Micro-organismo alvo & $\begin{array}{l}\text { Alimento } \\
\text { aplicado }\end{array}$ & Autor e data \\
\hline Base celulósica & Orégano & $\begin{array}{l}\text { Penicilliumspp; } \\
\text { Staphylococcus aureus. }\end{array}$ & $\begin{array}{l}\text { Massa pronta de } \\
\text { pizza }\end{array}$ & Botre et al., 2010 \\
\hline Proteína da soja & Orégano e tomilho & $\begin{array}{l}\text { Bactérias heterotróficas; } \\
\text { Bactéria ácido láctica; } \\
\text { Coliformes; } \\
\text { S. aureus; } \\
\text { Pseudomonasaeruginosa }\end{array}$ & $\begin{array}{l}\text { Carne moida para } \\
\text { hambúrguer }\end{array}$ & $\begin{array}{l}\text { Emiroğlu et al., } \\
2010\end{array}$ \\
\hline Quitosana & $\begin{array}{l}\text { OE de cravo } \\
\text { (Syzygiumaromaticum } \\
\text { L.) }\end{array}$ & $\begin{array}{l}\text { Pseudomonasfluorescens; } \\
\text { Listeriainnocua; } \\
\text { Escherichia coli; } \\
\text { Lactobacillusacidophilus }\end{array}$ & $\begin{array}{l}\text { Peixe(Gadusmor } \\
\text { hua) }\end{array}$ & $\begin{array}{l}\text { Gómez-Estaca et } \\
\text { al., } 2010\end{array}$ \\
\hline Quitosana & Óleo de bergamota & Penicilliumitalicum & N/A & $\begin{array}{l}\text { Sanchez- } \\
\text { Gonzalez et al. } \\
2010\end{array}$ \\
\hline Quitosana & Canela & $\begin{array}{l}\text { L. monocytogenes; } \\
\text { E. coli; } \\
\text { Lactobacillusplantarum; } \\
\text { Lactobacillussakei; } \\
\text { Pseudomonasfluorescens }\end{array}$ & N/A & Ojaghet al., 2010 \\
\hline $\begin{array}{l}\text { Hydroxypropyl } \\
\text { methylcellulose } \\
\text { (HPMC) }\end{array}$ & $\begin{array}{l}\text { Bergamota, limão e } \\
\text { melaleuca }\end{array}$ & $\begin{array}{l}\text { Listeriamonocytogenes; } \\
\text { E. coli; } \\
\text { Staphylococcusaureus }\end{array}$ & N/A & $\begin{array}{l}\text { Sánchez- } \\
\text { González et al., } \\
2011\end{array}$ \\
\hline Quitosana & $\begin{array}{l}\text { Bergamota, limão e } \\
\text { melaleuca }\end{array}$ & & & \\
\hline $\begin{array}{l}\text { Acetato } \quad \mathrm{de} \\
\text { celulose }\end{array}$ & $\begin{array}{l}\text { Óleo essencial de } \\
\text { alecrim }\end{array}$ & $\begin{array}{l}\text { Bactériaspsicrófilas; } \\
\text { coliformes totais e coliformes } \\
\text { termotolerantes; } \\
\text { Staphylococcuscoagulase } \\
\text { positiva; } \\
\text { Salmonellaspp. }\end{array}$ & Frango & Melo et al., 2012 \\
\hline Quitosana & Thymuskotschyanus & $\begin{array}{l}\text { L. monocytogenes; } \\
\text { E. coli O157: H7; } \\
\text { S. aureus; } \\
\text { S. typhimurium. }\end{array}$ & N/A & $\begin{array}{l}\text { Mehdizadeh } \\
\text { et al., } 2012\end{array}$ \\
\hline $\mathrm{PP} / \mathrm{EVOH}$ & Orégano e Citral & $\begin{array}{l}\text { Escherichia coli; } \\
\text { Salmonella entérica; } \\
\text { Listeriamonocytogenes }\end{array}$ & N/A & $\begin{array}{l}\text { Muriel-Galet et } \\
\text { al., } 2012\end{array}$ \\
\hline Quitosana & Alecrim & $\begin{array}{l}\text { ListeriamonocytogenesPseud } \\
\text { omonasPutida; } \\
\text { Streptococcusagalactiae; } \\
\text { Escherichia coli } \\
\text { Lactococcuslactis } \\
\end{array}$ & N/A & $\begin{array}{l}\text { Abdollahi et al., } \\
2012\end{array}$ \\
\hline Gliadin & Aldeído cinâmico & $\begin{array}{l}\text { P. expansum } \\
\text { Aspergillusniger }\end{array}$ & Pão; queijo & $\begin{array}{l}\text { Balaguer et al., } \\
2013 \\
\text { Original }\end{array}$ \\
\hline Amido de milho & $\begin{array}{l}\text { Zataria multiflora } \\
\text { BoisseMenthapulegium }\end{array}$ & $\begin{array}{l}\text { Escherichia coli; } \\
\text { Staphylococcus aureus }\end{array}$ & N/A & $\begin{array}{l}\text { Ghasemlou et al., } \\
2013\end{array}$ \\
\hline Quitosana & Carvacrol & $\begin{array}{l}\text { S. typhimurium; } \\
\text { E. coliO157:H7 }\end{array}$ & N/A & López et al., 2013 \\
\hline $\begin{array}{l}\text { Amido } \quad \text { de } \\
\text { mandioca }\end{array}$ & Canela & $\begin{array}{l}\text { P. commune; } \\
\text { E. amstelodami }\end{array}$ & N/A & $\begin{array}{l}\text { Souza et al., } \\
2013\end{array}$ \\
\hline $\begin{array}{ll}\text { Filme } & \text { de } \\
\text { proteína } & \text { de } \\
\text { girassol } & \end{array}$ & Cravo da índia & $\begin{array}{l}\text { A. niger; } \\
\text { P. expansum. } \\
\text { P. hosphoreum; } \\
\text { B. hermosphacta }\end{array}$ & Sardinha & $\begin{array}{l}\text { Salgado et al., } \\
2013\end{array}$ \\
\hline $\begin{array}{l}\text { Filme proteico } \\
\text { de Triticale }\end{array}$ & Orégano & $\begin{array}{l}\text { Staphylococcus aureus; } \\
\text { Escherichia coli; } \\
\text { Pseudomonasaeruginosa }\end{array}$ & N/A & $\begin{array}{l}\text { Aguirre et al., } \\
2013\end{array}$ \\
\hline
\end{tabular}




\begin{tabular}{|c|c|c|c|c|}
\hline $\begin{array}{l}\text { Tereftalato } \\
\text { de Etileno (PET) }\end{array}$ & Canela & Aspergillusflavus & N/A & $\begin{array}{l}\text { Manso et al., } \\
2013\end{array}$ \\
\hline Base celulósica & Aldeído cinâmico & $\begin{array}{l}\text { S. aureus } \\
\text { L. monocytogenes } \\
\text { E. coli } \\
\text { Fusariumoxysporum } \\
\text { Aspergillusflavus }\end{array}$ & N/A & Lopes et al., 2014 \\
\hline Quitosana & $\begin{array}{l}\text { Limão, tomilho e } \\
\text { canela }\end{array}$ & $\begin{array}{l}\text { E. coli; } \\
\text { S. aureus }\end{array}$ & N/A* & Peng\& Li, (2014) \\
\hline $\begin{array}{l}\text { Polissacarídeo } \\
\text { de soja }\end{array}$ & $\begin{array}{l}\text { Zataria multiflora } \\
\text { BoisseMenthapulegium }\end{array}$ & $\begin{array}{l}\text { S. aureus; } \\
\text { Bacilluscereus; } \\
\text { E. coli O157:H7; } \\
\text { Pseudomonasaeruginosa; } \\
\text { Salmonellatyphimurium. }\end{array}$ & N/A & $\begin{array}{l}\text { Salarbashi et al., } \\
2014\end{array}$ \\
\hline Gelatina & Zataria multiflora & $\begin{array}{l}\text { Pseudomonasaeruginosa; } \\
\text { Escherichia coli; } \\
\text { Staphylococcus aureus; } \\
\text { Bacillussubtilis, }\end{array}$ & N/A & $\begin{array}{l}\text { Kavoosi et al., } \\
2014\end{array}$ \\
\hline $\begin{array}{ll}\text { Mucilagem } & \text { de } \\
\text { semente } & \text { de } \\
\text { marmelo } & \end{array}$ & Orégano & $\begin{array}{l}\text { Staphylococcus aureus; } \\
\text { Escherichia coli; } \\
\text { Shewanellaputrefaciens; } \\
\text { Yersiniaenterocolitica }\end{array}$ & N/A & Jouki et al., 2014 \\
\hline $\begin{array}{l}\text { Quitosana/ } \\
\text { cyclodextrina }\end{array}$ & Carvacrol & $\begin{array}{l}\text { Bactérias mesófilas; } \\
\text { Bactérias psicrófilas; } \\
\text { Pseudomonasspp., } \\
\text { Enterobactérias } \\
\text { Bactérias ácido lácticas; } \\
\text { Fungos }\end{array}$ & Frango & $\begin{array}{l}\text { Higueras et al., } \\
2014\end{array}$ \\
\hline $\begin{array}{l}\text { Proteína de soro } \\
\text { de leite } \\
\text { concentrada }\end{array}$ & Canela & $\begin{array}{l}\text { Lactobacilluslactis; } \\
\text { Pseudomonasputida; } \\
\text { Streptococcusagalactiae; } \\
\text { Escherichia coli; } \\
\text { Listeriamonocytogenes; } \\
\text { Bacillussubtilis; } \\
\text { Candidaalbicans }\end{array}$ & N/A & $\begin{array}{l}\text { Bahram et al., } \\
2014\end{array}$ \\
\hline Polipropileno & Canela & Aspergillusflavus & N/A & $\begin{array}{l}\text { Manso et al., } \\
2014\end{array}$ \\
\hline Gelatina & Capim limão & $\begin{array}{l}\text { Bactérias ácido lácticas; } \\
\text { Bactériaspsicrófilas } \\
\text { incluindo bactérias } \\
\text { produtoras de } \mathrm{H}_{2} \mathrm{~S} ; \\
\text { Enterobactérias }\end{array}$ & $\begin{array}{l}\text { Peixe } \\
\text { (Latescalcarifer) }\end{array}$ & $\begin{array}{l}\text { Ahmad et al., } \\
2016\end{array}$ \\
\hline
\end{tabular}

Fonte: Autores, 2018

N/A*: Não aplica

Artigos que mostram a utilização de $\mathrm{OE}$ em bactérias são reportadospor Peng \& Li, (2014) utilizaram a combinação de 3 OE frente às bactérias E.coli e S.aureu; resultado semelhante também foi percebido por Ghasemlou et al. (2013) utilizando filme a base de amido de milho e óleos essenciais de Zataria multiflora Boiss e Menthapulegium frente as bactérias E.coli e S.aureus.

Trabalho realizado por Emiroğlu et al. (2010), fala sobre a utilização de filmes a base de proteína de soja incorporados com óleo essencial de orégano e tomilho, contra a ação deletéria de Escherichia coli, E. coli O157:H7, Staphylococcus aureus, Pseudomonasaeruginosa e Lactobacillusplantarum, procedimentos realizados in vitro.

Estudo realizado por Kavoosiet al. (2014) com filmes a base de gelatina com OE de Zataria multiflora, verificou a inibição de bactérias gram-positivas, Staphylococcus aureus e Bacillussubtilis e bactérias gram-negativas Pseudomonasaeruginosa e Escherichia coli.
Destacamos também os resultados de López et al. (2013), utilizando carvacrol em filmes de quitosana com a finalidade de diminuir a população microbiana de $S$. typhimuriume $E$. coliO157:H7.

Pesquisa realizada por Melo et al. (2012) com óleo essencial de alecrim em filmes a base de acetato de celulose, testou em cortes de frango para inibir bactérias psicrófilas, coliformes totais e coliformes termotolerantes, Staphylococcus coagula se positiva e Salmonella spp. O filme com uma concentração de $50 \%$ de OE foi eficaz na redução da contagem de coliformes totais.

\section{4 - Embalagem ativa e o aumento da vida de prateleira}

O objetivo das pesquisas em busca de novas embalagens ativas tem como finalidade estender a vida de prateleira do produto, mantê-lo integro em suas características sensoriais, e livres de contaminação microbiológica. As embalagens ativas podem ser aplicadas em diferentes produtos: pão e queijo 
(BALAGUER et al., 2013), carne (EMIROĞLU et al., 2010), frango (MELO et al., 2012) apontados no quadro 1.

Estudo conduzido por Balagueret al. (2013) utilizando filmes de gliadin incorporados com $5 \%$ de cinamaldeido prolongaram a vida de prateleira do pão fatiado, o mesmo permaneceu sem aparecimento de fungos por 27 dias, enquanto que o pão utilizado como controle, ou seja, sem embalagem ativa, apresentou os fungos $P$. expansum e Aspergillusniger após 4 dias. Ainda segundo os autores, os resultados foram observados para o queijo, a embalagem ativa foi capaz de retardar o crescimento fúngico por 26 dias, contra 16 dias do queijo utilizado como controle.

Trabalho realizado por Gómez-Estacaet al. (2010) mostrou a aplicação de óleo essencial de cravo em filmes de quitosana, para controle de bactérias deteriorantes em amostras de peixe (Gadusmorhua), os resultados mostraram atividade antimicrobiana significativa para 4 micro-organismos distintos, Pseudomonasfluorescens; Listeriainnocua; Escherichia coli; Lactobacillusacidophilus, o que confirma o potencial de utilização dos óleos essenciais no controle de uma população microbianaaumentando a vida de prateleira das amostras de peixe armazenadas.

Estudo conduzido por Ahmadet al., (2012), também realizado com amostras de peixe (Lates calcarifer), trouxe os resultados da incorporação de óleo essencial de capim limão em filmes de gelatina para o controle de bactérias ácido lácticas, bactérias psicrófilas, incluindo bactérias produtoras de $\mathrm{H}_{2} \mathrm{~S}$ e enterobactérias. O objetivo do trabalho foi demostrar o potencial do filme, em promover a redução da contagem global dos microrganismos listados acima, o que foi observado durante 12 dias, o tempo que as amostras permaneceram armazenadas.

\section{CONCLUSÃO}

Alguns estudos fazem os testes antimicrobianos com microrganismos específicos, outros o fazem apenas com grupos de bactérias e verificam sua contagem global. As formas empregadas por cada autor estão relacionadas ao tipo de alimento e ao destino que se pretende dar ao filme produzido, visto que alguns autores não relacionam o filme produzido a um alimento específico. Somente alguns trabalhos relatam a aplicação direta sobre o alimento e verificam a sua viabilidade.

É importante destacar que nos últimos anos o tema de embalagens ativas vem sendo amplamente pesquisado e discutido, tendo em vista o uso nos alimentos de forma segura, aos consumidores.

O presente estudo apresenta limitações, considerando que há necessidade investigações mais amplas, tendo em vista a constate descoberta e renovação do uso de embalagens, deste modo acredita-se que a continuidade do estudo se faz relevante, ampliando a correlação usada e abordada nessa pesquisa. Com essa pesquisa foi possível contribuir com a amplitude do tema em questão, demonstrando que é possível aumentar a vida de prateleira dos alimentos testados e até que ponto se pode utilizar determinadas formas de conservação.

Diante do exposto podemos concluir que os óleos essenciais ou seus isolados incorporados aos filmes têm apresentado resultados significativos na redução ou inibição do crescimento microbiano, e que há uma diversidade de filmes e óleos com potencial de aplicabilidade na indústria de alimentos.

\section{REFERÊNCIAS}

ABDOLLAHI, M.; REZAEI, M.; FARZI, G. Improvement of active chitosan film properties with Rosemary essential oil for food packaging, International. Journal of Food Science and Technology, v. 47, p. 847-853, 2012

AGUIRRE. A.; BORNEO, R.; LÉON, A. E. Antimicrobial, mechanical and barrier propertiesof triticale protein films incorporated with oregano essential oil. Food Bioscience, v.1, n. 1,p. 2- 9, 2013.

AHMAD, M.; BENJAKUL, S.; SUMPAVAPOL, P.; NIRMAL, N. P. Quality changes of seabass sliceswrappedwith gelatin film incorporated with lemongrass essential oil. International Journal of Food Microbiology, v. 155, n.3, p. 171-178, 2016.

APPENDINIA, P.; HOTCHKISSB, J. H. Review of antimicrobial food packaging. Innovative Food Science \&Emerging Technologies, v.3, n.2, p, 113-126, 2012.

BASTOS, M. S. R.; LAURENTINO, L. S.;SILVA, S. M. F.; MENDES L. G.; MARQUES, K. C.; GONÇALVES, N. P.; PEREIRA, R. C. A. Filme Biodegradável de Base Celulósica Incorporado de Óleos Essenciais. Comunicado Técnico 2017, Embrapa, Brasília, 2013.

BALAGUER, M. P. et al. Antifungal properties of gliadin films incorporating cinnamaldehyde and application in active food packaging of bread and cheese spread foodstuffs. International Journal of Food Microbiology, Amsterdam, v. 166, n. 3, p. 369-377, Sept. 2013.

BAHRAM, S.; REZAEI, M.; SOLTANI, M.; KAMALI, A.; OJAGH, S. M.; ABDOLLAHI, M. Whey protein concentrated ible film activated witch inn Amon essential oil. Journal of Food Processing and Preservation v.38, n.3, p.1251-1258, 2014.

BOTRE, D. A.; SOARES, N. F. F.; ESPITIA, P. J. P.; SOUSA, S. S.; RENHE, I. R. T. Avaliação de filme incorporado com óleo essencial de orégano para conservação de pizza pronta. Rev. Ceres, Viçosa, v. 57, n.3, p. 283-291, 2010.

BRANDELERO, R. P. H.; D. ALMEIDA, F. M.; ALFARO, A. The micro structure and properties of starch-polyvinylalcohol alginate film swith copaíba and lemongrass oils. Química Nova, v. 7, p. 910-916, 2015

CARDOSO, L.G.; SOUZA, C.A.; GUIMARÃES, A.G.. Prospecção tecnológica de patentes sobre a utilização de embalagens antimicrobianas em alimentos. Cad.Prospec., Salvador, v. 10, n. 1, p.14-23, 2017.

CAZÓN, P.; VELAZQUEZ, G.; RAMÍREZ, J. A.; VÁZQUEZ, M. Polysaccharide-based-films and coatings for food packaging: A review. Food Hydrocolloids, p. 1-13, 2016.

COZMUTA, A. M.; PETER, A.; NICULA, C.; COZMUTA, L. M. Assessment of the Effective Antioxidant Activity of Edible Films Taking into Account Films-Food Simulants and FilmsEnvironment Interactions. Packaging Technology and Science, v. 30, p. 3-20, 2017.

EMIROĞLU, Z. K.; YEMIŞ, G. P.; COŞKUN, B. K.; CANDOĞAN, K. Antimicrobial activity of soye dibble films incorporated withthy meand orégano essential oil son fresh ground beef patties. Meat Science, v. 86, n.2, p. 283-288, 2010.

FARIA, M.J.M. Antimicrobial Activity of Copaifera Spp. Against Bacteria Isolated From Milk of Cows With 
Mastitis. Ciênc. anim. bras. Goiânia , v. 18, n.3, p. 9098, 2017.

FIALHO E MORAES, A. R.; VIDIGAL, M. C.T.R.; SOARES, N. F. F.; MORAES, L. P.; MELO, N. R.; GONÇALVES, M. P. J. Desenvolvimento e avaliação de filme antimicrobiano aromatizado para aplicação em massa de pastel. Ciência Rural, v.41, n.3, p. 537-543, 2011

GHASEMLOU, M.; ALIHEIDARI, N.; FAHMI, R.; SHOJAEE-ALIABADI, S.; KESHAVARZ B.; CRAN, M. J.; KHAKSAR, R. Physical, mechanical and barrier properties of cornstarch films incorporated with plant essential oils. Carbohydrate Polymers, v. 98, n.1, p. 1117- 1126, 2013.

GÓMEZ-ESTACA, J.; DE LACEY, A. L.; LÓPEZCABALLERO, M. E.; GÓMEZ-GUILLÉN, M. C., MONTERO, P. Biodegradable gelatin e chitosan films incorporated with essential oils as antimicrobial agents for fishpreservation. Food Microbiology, v. 27, n.7, p. 889-896, 2010.

HIGUERAS, L.; LÓPEZ-CARBALLO, G.; HERNÁNDEZMUÑOZ, P.; CATALÁ R.; GAVARA, R. Antimicrobial packaging of chicken fillets based on the release of carvacrol from chitosan/cyclodextrin films. International Journal of Food Microbiology, v.188, n.1, p. 53-59, 2014.

KAVOOSI, G.; RAHMATOLLAHI, A.; DADFAR, S. M..; PURFARD, A. M. Effects of essential oil on the water bind ing capacity, physicomechanical properties, antioxidant and antibacterial activity of gelatina films. LWT - Food Science and Technology, v. 57, n. 2, p. 556-561, 2014.

LOPES, F. A.; SOARES, N. F. F.; LOPES, C. C. P.; SILVA, W. A. Desenvolvimento e caracterização de filmes de base celulósica incorporados com aldeído cinâmico. Brasil Journal of Food Technology, Campinas, v. 17, n. 1, p. 33-40, 2014.

LÓPEZ, M. A, M.; RUIZ-CRUZ, S.; BELTRÁN, N. P. S.; PAZ, J. J. O.; FLORES, P. B. Z.; BURRUEL-IBARRA, S. E. Physico chemical, Antimicrobial and Antioxidant Properties of Chitosan Films Incorporated with Carvacrol. Molecules, v.18, n.11, p.13735-13753, 2013.

MANSO, S.; CACHO-NERIN, F.; BECERRIL, R.; NERÍN, C. Combine danalytical and microbiological tools to study the effecton Aspergillus flavus of cinnam on essential oil contained in food packaging. Food Control, v. 30, n.2, p. 370-378, 2013.

MANSO, S.; PEZO, D.; GÓMEZ-LUS, R.; NERÍN, C. Diminution of Aflatoxin B1 production caused by anactive packaging containing cinnamon essential oil. Food Control, v. 45, n.1, p. 101-108, 2014.

MEHDIZADEH, T.; TAJIK, H.; ROHANI, S. M. R.; OROMIEHIE, A. R. Antibacterial, antioxidant and optical properties of ediblestarch-chitosan composite film containing Thymuskotschyanus essential oil. Veterinary Research Forum, v.3, n.3, p.167-173, 2012.

MELO, A. A. M.; GERALDINE, R. M.; SILVEIRA, M. F. A.; TORRES, M. C. L.; REZENDE, C. S. M.; FERNANDES, T. H.; OLIVEIRA, A. N.Microbiological quality and o the characteristics of refrigerated chick enmeat in contact with cellulose acetate-based film incorporated with Rosemary essential oil. Braz. J. Microbiology, v.43, n.4, p. 1419-1427, 2012.

MURIEL-GALET, V.; CERISUELO, J. P.; LÓPEZCARBALLO, G.; LARA, M.; GAVARA R. Development of antimicrobial films for microbiological control of packaged salad. International Journal of Food Microbiology, v. 157, n. 2, p. 195-201, 2012.

OJAGH, S. M.; REZAEI, M.; RAZAVI, S. H.; HOSSEINI, S. M. H. Development and evaluation of a novel biodegradable film made from chitosan and cinnamon essential oil with low affinity toward water. Food Chemistry, v. 122, n.1, p. 161-166, 2010.

PENG, Y.; LI, Y. Combined effects of wokind of essential oil sonphysical, mechanical and structural properties of chitosan films. Food Hydrocolloids, v.36, n. 1, p. 287-293, 2014.

REALINI, C. E.; MARCOS, B. Active and intelligent packaging systems for a modern society. Meat Science, v. 98, n.1, p. 404-419, 2014.

SALARBASHI, D.; TAJIK, S.; SHOJAEE-ALIABADI, S.; GHASEMLOU, M.; MOAYYED, H.; KHAKSAR, R.; NOGHABI, M. S. Development of new active packaging film made from a soluble bean polysaccharide incorporated Zataria multiflora Boissand Menthapulegium essential oils. Food Chemistry, v. 146, 614-622, 2014.

SALGADO, P. R.; LÓPEZ-CABALLERO, M. E.; GÓMEZGUILlÉN, M. C.; MAURI A. N.; MONTERO, M. P. Sun flower protein films incorporated with Love essential oil have potential application for the preservation of fish patties. Food Hydrocolloids, v. 33, n.1, p. 74-84, 2013.

SANCHEZ-GONZALEZ, L.; CHAFER, M.; CHIRALT, A.; GONZALEZ-MARTINEZ, C. Physical properties of edible chitosan films contain igbergamo et essential oil and the irinh ibitory action on Penicillium italicum. Carbohydrate Polymers, v. 82, n.3 p. 277-283, 2010.

SÁNCHEZ-GONZÁLEZ, L.; CHÁFER, M.; HERNÁNDEZ, M.; CHIRALT, A.; GONZÁLEZ-MARTÍNEZ, C. Antimicrobial activity of polysaccharide e films contain ingessential oils, Food Control v. 22, n.8, p. 1302-1310, 2011.

SINGH, P.; WANI, A. A.; SAENGERLAUB, S. Active packaging of food products: recent trends. Nutrition\& Food Science, v. 41, n. 4, p. 249 - 260, 2011.

SOUZA, A. C.; GOTO, G. E. O.; MAINARDI. J. A.; COELHO, A. C. V.; TADINI C. C. Cassava starch composite films incorporated withc innamon essential oil: Antimicrobial activity, microstructure, mechanical and barrier properties. LWT - Food Science and Technology, v.54, n. 2, p. 346-352, 2013.

\section{COPYRIGHT}

Direitos autorais: os autores são os únicos responsáveis pelo material incluído no artigo.

Submetido em: 05/12/2018 Aprovado em: 26/01/2019 


\section{Área: Ciências Exatas e Engenharias}

\begin{tabular}{|c|c|}
\hline $3-4$ & $\begin{array}{l}\text { INSTALAÇÕES ELÉTRICAS DE EQUIPAMENTOS ELETROMÉDICOS: } \\
\text { AVALIAÇÃO DOS IMPACTOS DA QUALIDADE DE ENERGIA EM INSTITUIÇÕES } \\
\text { DE SAÚDE } \\
\text { ELECTRICAL INSTALLATIONS OF MEDICAL ELECTRICAL EQUIPMENT: } \\
\text { ASSESSMENT OF POWER QUALITY IMPACTS IN HEALTH INSTITUTIONS } \\
\text { Edenilso Tonielo; Ghendy Cardoso Junior }\end{array}$ \\
\hline $3-5$ & $\begin{array}{l}\text { ANÁLISE NUMÉRICA DA INFLUÊNCIA DA VELOCIDADE DE SOLDA EM } \\
\text { VASOS DE PRESSÃO CILÍNDRICOS } \\
\text { NUMERICAL ANALYSIS OF THE INFLUENCE OF WELDING SPEED IN } \\
\text { CYLINDRICAL PRESSURE VESSELS } \\
\text { Fernanda Figueredo Santos; Jayann Ismar Lira Almeida }\end{array}$ \\
\hline $3-5$ & 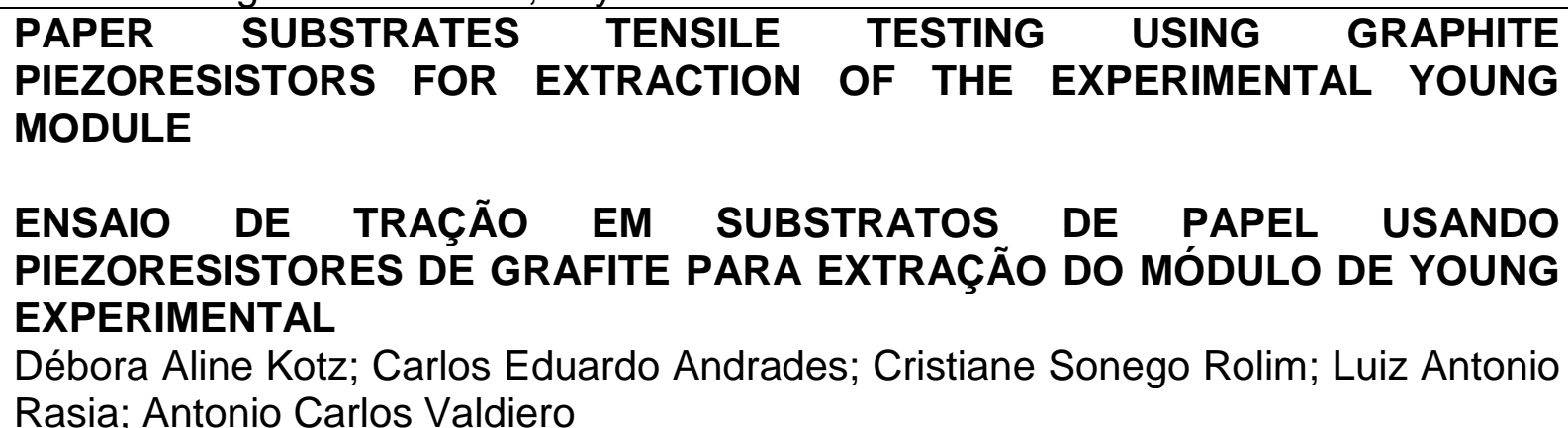 \\
\hline
\end{tabular}




\title{
Revista SODEBRAS - Volume 14 \\ $\mathrm{N}^{\circ} 158$ - FEVEREIRO/ 2019
}

\section{INSTALAÇÕES ELÉTRICAS DE EQUIPAMENTOS ELETROMÉDICOS: AVALIAÇÃO DOS IMPACTOS DA QUALIDADE DE ENERGIA EM INSTITUIÇÕES DE SAÚDE}

\section{ELECTRICAL INSTALLATIONS OF MEDICAL ELECTRICAL EQUIPMENT: ASSESSMENT OF POWER QUALITY IMPACTS IN HEALTH INSTITUTIONS}

\author{
EDENILSO TONIELO ${ }^{1}$; GHENDY CARDOSO JUNIOR ${ }^{2}$ \\ 1; 2 - UNIVERSIDADE FEDERAL DE SANTA MARIA \\ edenilsotonielo@gmail.com
}

\begin{abstract}
Resumo - Este trabalho tem como objetivo avaliar o nível de poluição harmônica em instituições de saúde, de modo a comprovar, o risco de diagnósticos médicos baseados em informações fornecidas por equipamentos eletromédicos alimentados em redes elétricas que não atendam à norma vigente ou totalmente perturbadas por outros equipamentos típicos dos ambientes médico-hospitalares, contribuindo com à área de saúde, os fabricantes poderão melhorar seus equipamentos, assim como as concessionárias fornecerem energia elétrica de qualidade. A metodologia quantitativa foi aplicada e consistiu em medições de parâmetros de qualidade de energia elétrica, como harmônicos $e$ afundamentos de tensão, em instituiçães de saúde. Foram analisados equipamentos de raio-X, mamografia, tomografia, radioterapia e hemodinâmica e por meio de uma pesquisa de campo com base nos resultados fornecidos pelos equipamentos, além da realização de uma revisão bibliográfica com ênfase no problema da qualidade de energia e dos Equipamentos Eletromédicos. Os resultados obtidos comprovam a importância de constante avaliação da qualidade de energia elétrica e das instalações elétricas.
\end{abstract}

Palavras-chave: Qualidade de Energia Elétrica. THD. Equipamentos Eletromédicos.

Abstract: The objective of this study is to evaluate the level of harmonic pollution in health institutions, in order to prove the risk of medical diagnoses based on information provided by medical electrical equipment fed into electrical networks that do not meet the norm in force or totally disturbed by other typical equipment of the medical-hospital environments, contributing to the health area, manufacturers can improve their equipment, as well as the concessionaires provide quality electricity. The quantitative methodology was applied and consisted of measurements of electric power quality parameters, such as harmonics and voltage sags, in health institutions. X-ray, mammography, tomography, radiotherapy and hemodynamic equipment were analyzed, as well as a field survey based on the results provided by the equipment, as well as a bibliographical review with emphasis on the problem of energy quality and the Medical Electrical Equipment. The results obtained prove the importance of constant evaluation of the quality of electric power and electrical installations.

Keywords: Power Quality. THD. Medical Electrical Equipment.

\section{INTRODUÇÃO}

A evolução da tecnologia proporcionou o desenvolvimento da medicina em benefício a saúde humana.
Equipamentos modernos, novos processos de diagnóstico médico, tratamentos e técnicas cirúrgicas utilizam-se cada vez mais de equipamentos de última geração, projetados e construídos com avançadas tecnologias eletrônicas e totalmente informatizados. No entanto, esta tecnologia moderna é sensível a perturbações elétricas, sendo essencial a qualidade das instalações elétricas nos ambientes médicohospitalares, bem como a qualidade de energia elétrica fornecida ao funcionamento desses equipamentos.

No setor industrial existe uma preocupação com a qualidade de energia, tanto por parte dos consumidores como pelas concessionárias de energia. Esta preocupação justificase, principalmente, por questões econômicas. Nos Estabelecimentos Assistenciais de Saúde (EAS) observamos que as instalações elétricas não são projetadas e nem mantidas com a mesma qualidade da indústria. A preocupação com a qualidade da energia elétrica e as instalações devem ser ainda maiores nos EAS, uma vez que a questão econômica também é relevante e justifica a busca por qualidade, mas a principal preocupação é o risco a vida dos pacientes. Conforme Martinho (2009), instalações especiais como em hospitais, requerem um índice muito elevado de cuidados com relação a energia elétrica, com acompanhamento e medições constantes. Neste tipo de instalação um problema causado pela má qualidade de energia pode causar danos irreparáveis, como a morte de pacientes (MARTINHO, 2009).

A vida humana sempre deve ser priorizada, todo esforço possível deve ser considerado, para diminuir falhas de equipamentos e ou erros médicos que possam resultar em redução do número de óbitos. Neste trabalho é feita uma revisão bibliográfica sobre o problema da qualidade de energia e dos Equipamentos Eletromédicos (ELM) nos estabelecimentos de saúde. É proposta melhoria da normalização e fiscalização das instalações elétricas e equipamentos, visando a segurança do paciente.

Um estudo onde foram realizados ensaios da qualidade de energia em ELMs o que possibilitou a ampliação dos objetivos a partir dos testes realizados, com isso, foi possível demonstrar que os equipamentos, podem apresentar problemas em seu funcionamento devido a perturbações ou oscilações na rede elétrica e também avaliar distúrbios da qualidade de energia, especialmente os afundamentos de tensão, interrupções e harmônicos. 
Além do já exposto, foram também consideradas as características técnicas, os ensaios nos ELMs de pequeno porte cujo foco principal foram os problemas de funcionamento. Neste grupo estão equipamentos como monitores cardíacos, oxímetro de pulso, respiradores, bisturi elétrico, aparelhos de anestesia, máquinas de hemodiálise. A análise da qualidade de energia foi diretamente observada no quadro de energia que os alimenta, portanto foram analisados em conjunto. Para as máquinas de grande porte os ensaios de qualidade de energia elétrica, foram realizados individualmente e no local onde esses equipamentos se encontravam instalados e fixados, uma vez que apresentam maior probabilidade de gerar distorções. Foram eles: raio X, hemodinâmica, radioterapia, tomografia, mamografia.

\section{ASPECTOS TEÓRICOS}

\section{1 - Definição de Equipamento Eletromédico}

Para fins de padronização e evitar questionamentos, em 1977 foi publicada a primeira edição da norma IEC 60601-1 pela Comissão Internacional de Eletrotécnica (International Electrotechnical Commission). No texto desta norma os equipamentos eletromédicos seriam equipamentos elétricos específicos para uso no ambiente do paciente e relacionado de tal maneira a ele que a segurança poderia ser influenciada. Apesar de esta definição englobar indiretamente as definições das normas que a sucederiam, ela é muito genérica, e diversos equipamentos que hoje não são considerados como eletromédicos se encaixariam nesta definição, a definição foi revisada e de acordo com a NBR IEC 60601-1 (2016, p. 16) um Equipamento Eletromédico (Medical Electrical Equipment) é:

\begin{abstract}
"Equipamento elétrico que possui parte aplicada ou que transfere energia do ou para o paciente ou detecta tal transferência de energia de ou para o paciente e que é: - fornecido com não mais que uma conexão a uma rede de alimentação elétrica particular; - e destinado por seu fabricante para ser utilizado: - no diagnóstico, tratamento ou monitorização de um paciente; - ou compensação ou alívio de doença, ferimento ou invalidez (NBR IEC 60601-1, p.16, 2016)."
\end{abstract}

Cabe ressaltar que esta norma, de acordo com seu histórico, tem um tempo de validade de no mínimo dez anos, o que garante a este trabalho uma validação da definição para ser utilizada na pesquisa.

No Brasil, através da Instrução Normativa $\mathrm{N}^{\circ} 8$, de 08 de julho de 2009, adotou a norma técnica NBR IEC 60601-1 e as normas particulares NBR 60601-2-xx para certificação de quaisquer equipamentos elétricos sob o regime da vigilância sanitária. As normas particulares se referem a prescrições particulares de segurança de equipamentos que se enquadram na norma geral.

\section{2 - Normas técnicas}

No que se refere a equipamentos eletromédicos a norma aplicável é a NBR IEC 60601-1 de 2016, esta norma tem como objetivo principal estabelecer as condições mínimas de segurança e o desempenho dos equipamentos eletromédicos. Conforme destacado nos trabalhos de Ramos (2009) e Ramos (2013) no tocante as instalações elétricas temos a NBR 13534 que estabelece os padrões para as instalações especificamente dos ambientes hospitalares, a energia deve ser fornecida de tal forma que seja compatível com as exigências e a segurança específicas para cada local de finalidade médica, a NBR 5410 estipula as condições necessárias para o funcionamento adequado e seguro das instalações elétricas de baixa tensão em geral.

\section{2 - Qualidade de energia}

A qualidade da energia é um conjunto de limites elétricos que permite que um equipamento desenvolva sua função sem perda significativa de desempenho ou expectativa de vida (SANKARAN, 2002). Outra definição caracteriza a qualidade da energia elétrica pelo fornecimento de energia em tensão com forma de onda senoidal pura, sem alterações em amplitude, frequência ou fase, qualquer desvio significativo representa um potencial problema de qualidade de energia (DUGAN, 2003). Conforme Pinto (2016) o termo Qualidade de Energia Elétrica refere-se a uma variedade de fenômenos eletromagnéticos que caracterizam a corrente e a tensão em um dado instante e posição em um sistema elétrico. Abordaremos na sequência alguns dos fenômenos relevantes a esta pesquisa.

\subsection{1 - Harmônicos}

Os harmônicos são componentes de frequência, em tensão ou corrente, que são múltiplos inteiros da frequência fundamental da rede elétrica. Combinados com a componente fundamental $(60 \mathrm{~Hz})$, produzem uma forma de onda distorcida (PINTO, 2016).

Para definir os harmônicos Sankaran (2002) usa a do dicionário, os harmônicos são como um conjunto de sons puros que compõem um som composto na música. Um som puro é um som musical de uma única frequência, e uma combinação de muitos sons puros compõem um som composto. As ondas sonoras são ondas eletromagnéticas que viajam através do espaço como uma função periódica do tempo.

\subsection{2 - Distorção Harmônica}

As distorções harmônicas são fenômenos associados a deformações nas formas de onda das tensões e correntes em relação à onda senoidal da frequência fundamental. Os harmônicos estão associados ao uso em massa de cargas não lineares, podendo ser provocado internamente pelo próprio consumidor.

Distorção Harmônica Total (THD) é uma importante ferramenta utilizada para quantificar o nível de harmônicas nas formas de onda de tensão e corrente.

A taxa de distorção harmônica $T H D_{(v)}$ de tensão é definida pela equação 1 (NASSIF, et al. 2018):

$$
T H D_{(v)}=\frac{\sqrt{\sum_{n=2}^{\infty} V_{n}^{2}}}{V_{1}}
$$

A taxa de distorção harmônica $T H D_{(i)}$ de corrente é definida pela equação 2 (NASSIF, et al. 2018):

$$
T H D_{(i)}=\frac{\sqrt{\sum_{n=2}^{\infty} I_{n}^{2}}}{I_{1}}
$$

A taxa de distorção harmônica é uma notação muito utilizada para definir a importância do conteúdo harmônico de um sinal alternado. A distorção harmônica total da tensão 
$T H D_{(v)}$ ou corrente $T H D_{(i)}$ é geralmente expressa como uma relação ou porcentagem da fundamental de tensão ou corrente.

\subsection{3 - Variação de Tensão de Curta Duração (VTCD)}

As VTCDs são eventos de afundamento e elevação de tensão com duração de 0,5 ciclos a alguns minutos, dependendo da norma a ser utilizada. Dentre os distúrbios da qualidade de energia os afundamentos são os mais comuns.

De acordo com Bollen (1999) um afundamento é muito mais um problema "global" do que uma interrupção. Reduzir o número de interrupções normalmente requer melhorias em um alimentador. Reduzir o número de afundamentos de tensão requer melhorias em vários alimentadores e, muitas vezes, até mesmo em linhas de transmissão distantes.

Conforme Deckmann e Pomilio (2017) a denominação de VTCD só é encontrada na norma brasileira, na norma Americana os afundamentos e elevações de tensão são denominados respectivamente de "voltage sag" e "voltage swell", a norma Europeia classificam os afundamentos e elevações como "voltage dips" e "voltage swell".

De acordo com Martinho (2009) a Associação de Fabricantes de Computadores (CBEMA) preocupada com os efeitos da variação de tensão nos equipamentos eletrônicos, desenvolveu um estudo e definiu as tolerâncias mínimas de variação de tensão que os equipamentos devem suportar, como resultado deste estudo foi criada uma curva de referência da tensão em função do tempo, onde quanto menor o tempo de variação, maior a chance de os equipamentos não serem afetados. Em 2002 a curva foi revisada e modificada para caracterizar melhor a sensibilidade destes equipamentos pelo ITI (Information Technology Industry Council). Na figura 1 temos a curva CBEMA/ITIC.

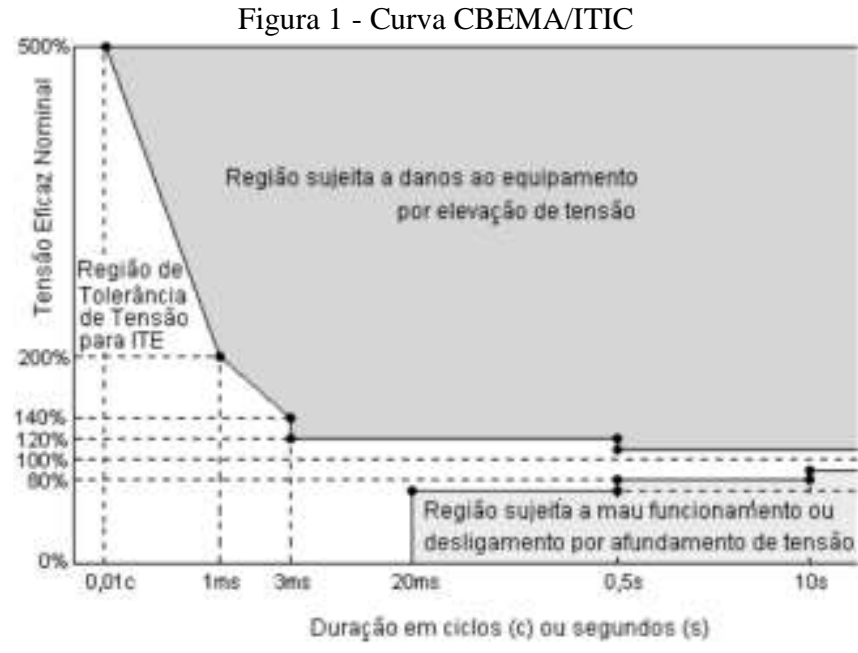

Fonte: Deckmann \& Pomilio, 2017.

Essa curva passou a ser uma referência para verificação do nível de vulnerabilidade de equipamentos comparando-se a curva de sensibilidade do equipamento com a curva das variações permitidas ou observadas durante um determinado intervalo de tempo (DECKMANN \& POMILIO, 2017).

\section{METODOLOGIA}

A metodologia adotada para o desenvolvimento deste estudo consistiu em medições quantitativas com revisão bibliográfica e ensaios em campo de parâmetros referentes a qualidade de energia em Instituições Assistenciais em Saúde
(EAS). Para os testes nos equipamentos ELMs, optou-se pela escolha de dois tipos de perturbações, os harmônicos e os afundamentos e interrupções de tensão de curta duração. Os ensaios foram priorizados em ELMs típicos dos EAS e passíveis de provocarem essas perturbações, mamógrafo, tomógrafo, radioterapia, hemodinâmica e raio-X. As medições foram realizadas com o analisador de qualidade de energia Fluke 435 equipado com sondas de corrente i400s e garras de tensão mostrado na figura 2 .

Figura 2 - Analisador de qualidade de energia Fluke 435

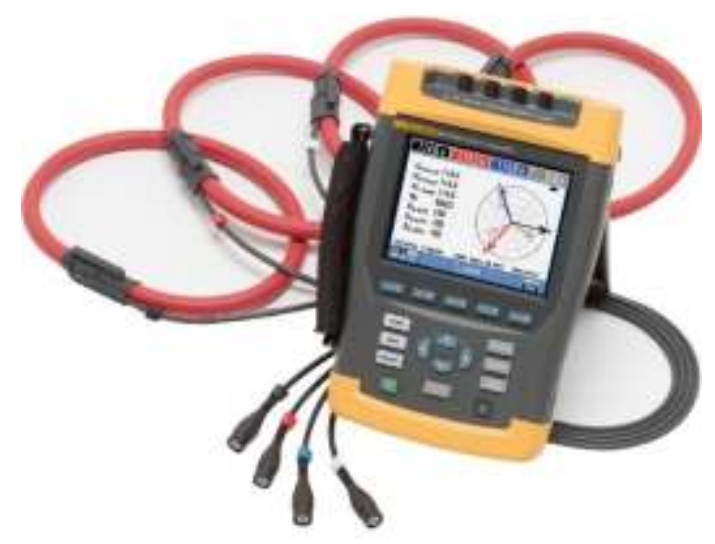

Fonte: Fluke.com

Este analisador atende todos os requisitos previstos no módulo 8 do PRODIST, IEC 61000-4-7, IEC 61000-4-30 e a recomendação IEEE 519/2014. Conforme dados do fabricante o equipamento possui faixa de medição de tensão de 1 até $1000 \mathrm{~V}$ com resolução de $0,01 \mathrm{~V}$. A faixa de medição de corrente pode variar de $0,5 \mathrm{~A}$ até $3000 \mathrm{~A}$ com resolução de 0,1 A. Possui taxa de amostragem de 500 amostras por ciclo (30.000 amostras por segundo) e conversor analógico de 16 bits. Realiza medições de diversos parâmetros elétricos de tensão, corrente e potência. Mede harmônicos até a $50^{\mathrm{a}}$ ordem e calcula a distorção harmônica total de tensão e corrente de acordo com a norma IEC 61000-4-7. Calcula outros indicadores de qualidade da energia como afundamentos, flutuações de tensão e desequilíbrios de tensão.

\section{RESULTADOS}

Os dados obtidos nos ensaios do equipamento de tomografia serão apresentados detalhadamente com os diversos indicadores de qualidade de energia analisados. De modo a evitar que o trabalho se torne extenso e repetitivo todas as figuras obtidas nos ensaios do tomógrafo serão apresentadas, os resultados dos demais ELMs ensaios foram sintetizados e estão dispostos no item 4.2 e na tabela 2.

\section{1 - Resultados dos ensaios do tomógrafo}

A tomografia computadorizada, ou TC, é um exame de imagem que utiliza raios $\mathrm{X}$ para gerar imagens transversais do corpo nos chamados cortes tomográficos, ou seja, uma série de seções fatiadas que serão posteriormente processadas por um computador para formar uma imagem completa, podendo ser dos ossos, de órgãos ou de tecidos. Este exame não causa dor e qualquer pessoa pode realizá-lo. O equipamento ensaiado neste estudo é apresentado na figura 3 , 
trata-se de um tomógrafo da marca Toshiba modelo Aquilon CXL com 64 canais, capaz de realizar 128 cortes (imagens) a cada giro $\left(360^{\circ} \mathrm{C}\right)$ do sistema de geração de raio-X.

Figura 3 - Equipamento de tomografia Aquilion CXL

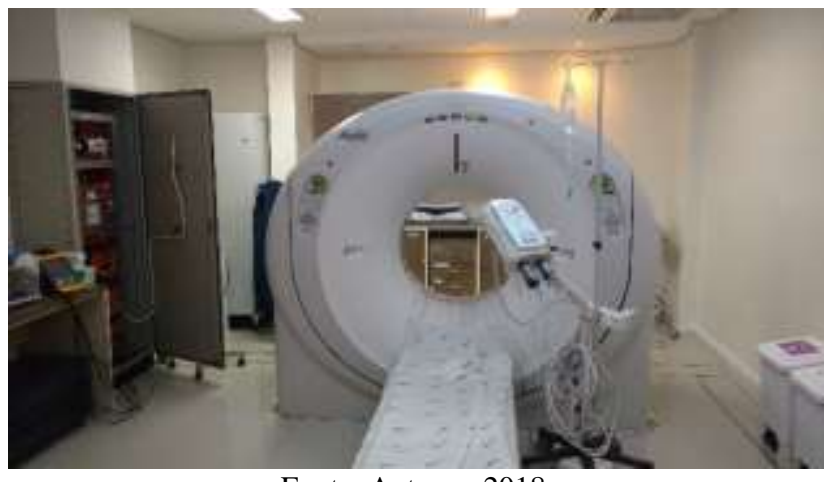

Fonte: Autores, 2018.

$\mathrm{O}$ equipamento tem funcionamento semelhante ao raio$\mathrm{X}$ e, portanto, produz corrente distorcida, tem demanda informada pelo fabricante de $100 \mathrm{KVA}$ trifásico $380 \mathrm{~V}$, sua ligação a rede elétrica é realizada através de um estabilizador de potência igual a demanda do equipamento. Os resultados obtidos nos ensaios deste equipamento serão apresentados em uma sequência de imagens a seguir, na figura 4 vemos o perfil de potência do tomógrafo.

Figura 4 - Tendência de potência e energia tomógrafo

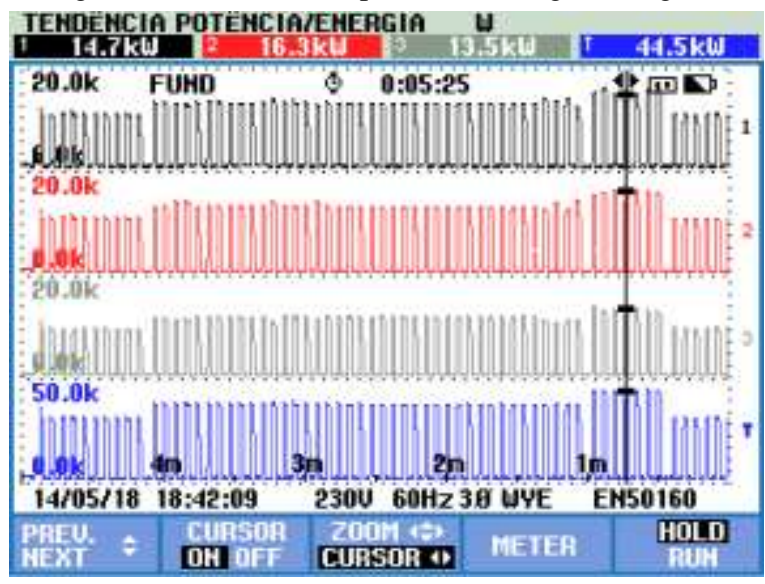

Fonte: Autores, 2018.

Na figura 4 conseguimos visualizar o comportamento da potência consumida pelo equipamento, tem um perfil bastante irregular, não é constante e nem linear, apresenta picos significativos que variam do zero ao máximo $(44 \mathrm{KW})$ mais de 60 vezes no intervalo de 5 minutos. Assim como no RX o perfil da corrente do tomógrafo pode levar a erros de dimensionamento da subestação de alimentação porque apresenta picos elevados por poucos segundos que são bem maiores que os do RX.

$\mathrm{Na}$ figura 5 temos a forma de onda de uma das fases do mesmo equipamento capturada 3 segundos antes dos dados de potência e energia.
Figura 5 - Forma de onda da tensão e corrente de uma das fases do tomógrafo

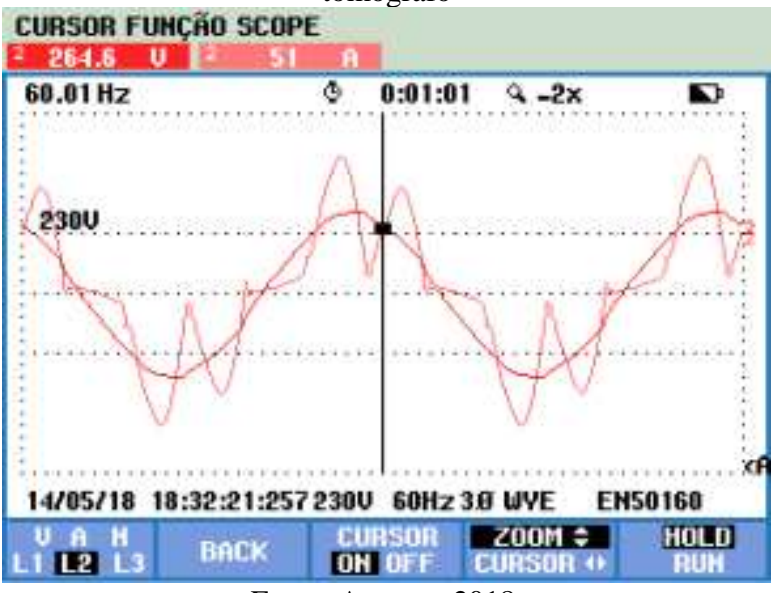

Fonte: Autores, 2018.

Como podemos observar na figura 5 , a forma de onda da corrente do tomógrafo é bem característica de cargas não lineares, possuindo picos não senoidais. E exatamente este tipo de corrente que gera distúrbios na rede elétrica, ou seja, os próprios equipamentos ELMs podem gerar distúrbios e afetar uns aos outros. Na figura 6 temos o diagrama fasorial das tensões no quadro do tomógrafo.

Figura 6 - Diagrama de fasores tomógrafo

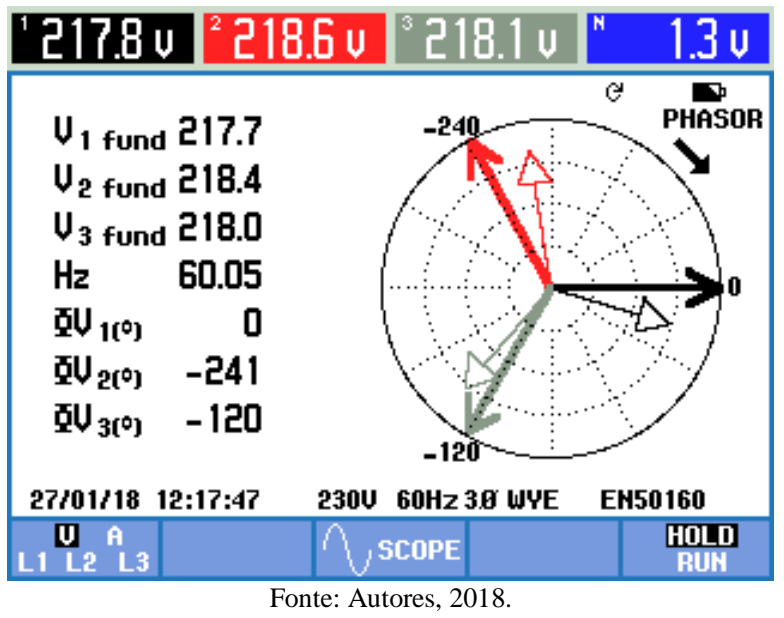

O equipamento de tomografia apresenta distorção harmônica de tensão de 3,5\% conforme podemos verificar na figura 7 .

Figura 7 - Distorção harmônica de tensão do tomógrafo $\left(T H D_{(v)}\right)$

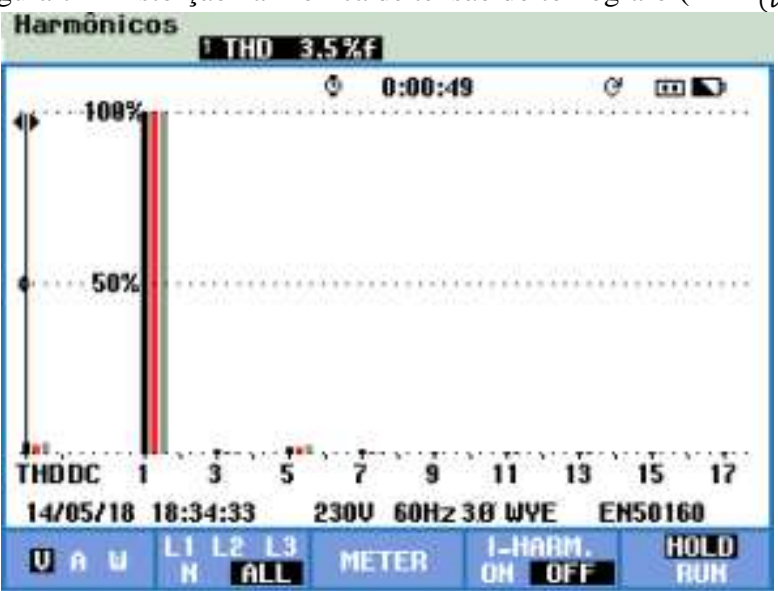

Fonte: Autores, 2018. 
Na figura 8 temos os valores da distorção harmônica de corrente, a $T H D_{(i)}$ medida tem valores elevados $(46,2 \%)$ devido a característica de carga não linear do tomógrafo.

Figura 8 - Distorção harmônica de corrente tomógrafo $\left(T H D_{(i)}\right)$

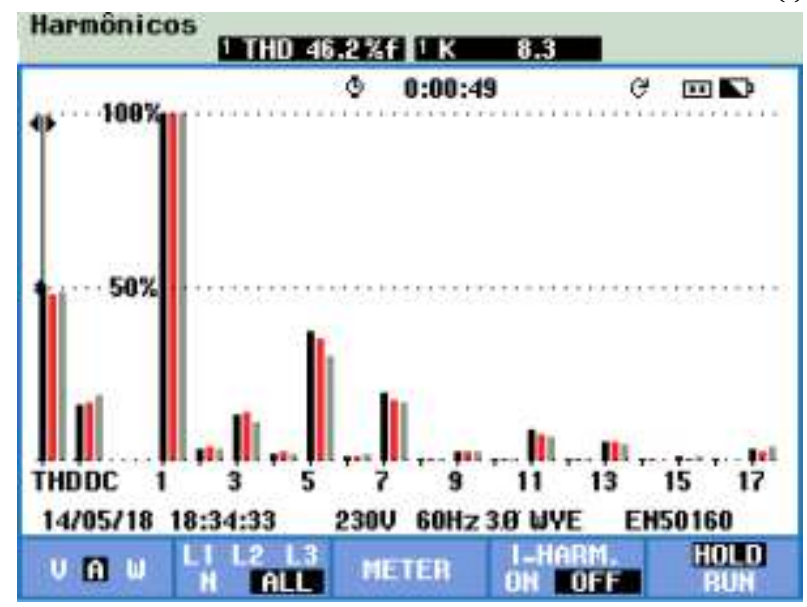

Fonte: Autores, 2018.

O conteúdo harmônico encontrado nos ensaios é elevado, sendo recomendado filtros para redução, no entanto, encontram-se dentro dos limites estabelecidos pelo Prodist (2018). Em todos os equipamentos ensaiados o principal problema associado a qualidade de energia foram os afundamentos, na figura 9 os níveis de afundamentos verificados nas medições do tomógrafo no intervalo de 7 dias.

Figura 9 - Afundamentos na medição do tomógrafo

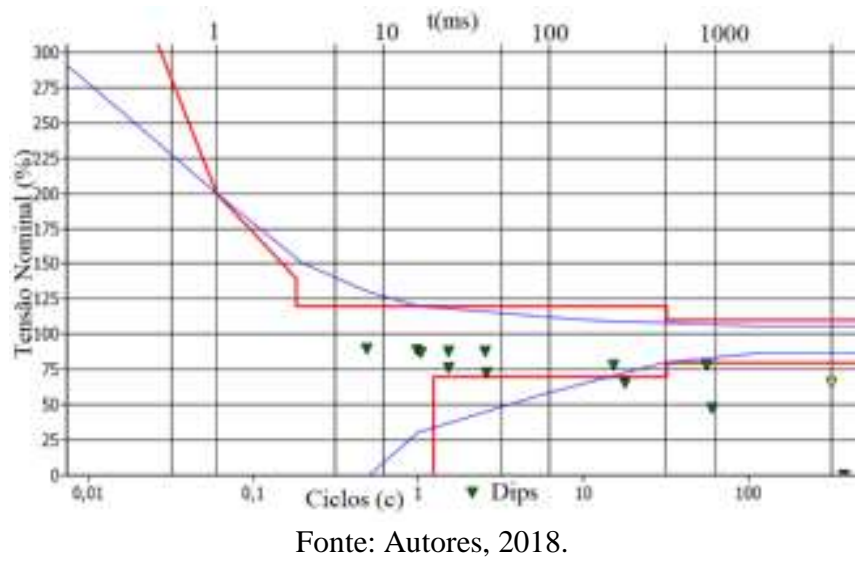

No levantamento dos registros dos afundamentos obtidos no analisador Fluke é possível identificar os afundamentos em relação a curva de referência de equipamentos eletrônicos CBEMA/ITIC conforme a figura 9, durante o intervalo de medição de 7 dias foram registrados 12 eventos de afundamentos, sendo 3 destes eventos fora dos limites de suportabilidade, ou seja, na região sujeita a mau funcionamento ou danos ao equipamento. Para visualização mais precisa dos pontos dos afundamentos temos os registros da tabela 1 .

Tabela 1 - Afundamentos nos ensaios do tomógrafo

\begin{tabular}{lrccccc}
\hline \multicolumn{2}{l}{ Tensão(\%) } & \multicolumn{7}{c}{ Duração $\mathrm{t}(\mathrm{s})$} \\
\hline & $\mathrm{t}<0,01$ & $0,01-0,2$ & $0,2-0,5$ & $0,5-1$ & $1-5$ & $5-6$ \\
\hline $90-80$ & 1 & 4 & 0 & 0 & 0 & 0 \\
\hline $80-70$ & 0 & 2 & 1 & 1 & 0 & 0 \\
\hline $70-40$ & 0 & 0 & 1 & 1 & 0 & 0 \\
\hline $40-5$ & 0 & 0 & 0 & 0 & 0 & 0 \\
\hline $5>\mathrm{V}$ & 0 & 0 & 0 & 0 & 1 & 1 \\
\hline
\end{tabular}

\section{2 - Comparação dos resultados}

Como comparação das cargas poluidoras apresentamos a tabela 2, nela são apresentadas algumas características do comportamento elétrico, como a corrente instantânea e em regime, bem como a distorção harmônica (THD), dos equipamentos que foram ensaiados individualmente.

Tabela 2 - Característica de Corrente e THD nos equipamentos ensaiados

\begin{tabular}{lcccc}
\hline Equipamento & $\begin{array}{l}\text { Corren } \\
\text { te } \\
\text { regime }\end{array}$ & $\begin{array}{l}\text { Corrente } \\
\text { pico }\end{array}$ & $\begin{array}{l}\text { THD } \\
(\%)\end{array}$ & $\begin{array}{l}T H D_{(v} \\
(\%)\end{array}$ \\
\hline Tomografia & 6,0 & 80,0 & 46,2 & 3,83 \\
Radioterapia & 17,0 & 51,0 & 46,2 & 3,50 \\
Hemodinâmica & 2,0 & 16,0 & 136,1 & 3,10 \\
Raio-X & 2,0 & 50,0 & 72,0 & 2,73 \\
Mamografia & 2,0 & 6,0 & 43,2 & 2,50 \\
\hline \multicolumn{5}{l}{ Fonte: Autores, 2018. }
\end{tabular}

Os resultados obtidos e apresentados na tabela 2 demostram a característica técnica de operação dos ELMs através das grandezas elétricas apresentadas, o comportamento da corrente de pico é até 25 vezes maior que a corrente em regime, esta característica ocorre devido aos picos de consumo nos momentos de geração do raio $\mathrm{X}$ que demanda corrente elétrica alta. Justamente a característica de picos de corrente que acabam gerando distorção harmônica de corrente altas de até $72 \%$.

Com relação aos afundamentos os equipamentos de RX, mamografia, radioterapia e hemodinâmica foram monitorados individualmente por 7 dias, sendo que em todos os ensaios, foram registrados afundamentos como na figura 9 do tomógrafo.

\section{CONCLUSÃO}

O presente estudo demonstrou a importância da qualidade de energia nas instituições de saúde. Os distúrbios associados a qualidade de energia, especialmente os harmônicos e os afundamentos, afetam o funcionamento dos equipamentos eletromédicos, causando reinicialização, funcionamentos inesperados, defeitos que prejudicam os tratamentos. Considerando o alto índice de cargas não lineares, recomenda-se a reforma de instalações antigas as quais no seu projeto original não foram previstas tais cargas, bem como as novas instalações devem seguir rigorosamente as normas vigentes e prever o atendimento de cargas não lineares em grande escala.

Frequentemente novas cargas são ligadas ao sistema elétrico do hospital, portanto as instalações elétricas destes estabelecimentos necessitam de uma avaliação periódica da Qualidade de Energia, suas especificações deverão seguir as normas e regulamentos disponíveis, e sua interação com as cargas geradoras de harmônicas deverá ser estudada.

Em todos os equipamentos ensaiados houve ocorrência de afundamentos, sendo este distúrbio o principal causador de mau funcionamento nos equipamentos. Uma forma de solução pontual para amenizar os danos ao equipamento afetado pelos afundamentos é a instalação de sistemas de armazenamento a base de baterias UPS (Uninterruptible Power Suply), no entanto, como os equipamentos de RX possuem demanda individual em torno de 100KVA necessitam de UPS robustas. 
Cabe também a gestão dos EAS de modo sistemático, dialogar e dar conhecimento as concessionárias de energia sobre os problemas causados em ELMs e aos resultados dos diagnósticos aos pacientes associados a baixa qualidade de energia disponibilizada. Esse dado é importante e que necessita ser priorizado quando a preocupação é a qualidade e o serviço prestado as instituições de saúde e a população usuária.

Com os resultados deste estudo concluímos que os fabricantes dos equipamentos necessitam melhora-los de modo a torná-los mais robustos, suportando afundamentos, evitando mau funcionamento ou danos.

\section{REFERÊNCIAS}

AGÊNCIA NACIONAL DE ENERGIA ELÉTRICA ANEEL. Procedimentos de Distribuição de Energia Elétrica no Sistema Elétrico Nacional. PRODIST, Módulo 8, Qualidade da Energia Elétrica. Resolução Normativa ${ }^{\circ}$ $794 / 2017$.

ASSOCIAÇÃO BRASILEIRA DE NORMAS TÉCNICAS. NBR 5410: Instalações Elétricas de Baixa Tensão. Rio de Janeiro, 2004. 208 p.

ASSOCIAÇÃO BRASILEIRA DE NORMAS TÉCNICAS. NBR 13534: Requisitos específicos para instalação em Estabelecimentos Assistenciais de Saúde. Rio de Janeiro, 2008. $21 \mathrm{p}$.

ASSOCIAÇÃO BRASILEIRA DE NORMAS TÉCNICAS. NBR IEC 60601-1: Equipamento eletromédico. Parte 1: Prescrições gerais para segurança. 1. ed. Rio de Janeiro, 2010. 358 p. Emenda, 2016, 129 p.

AZEVEDO, M. S. S.et al. Análise de Distorções Harmônicas em Pontos de um Barramento de Interesse do Sistema. Revista SODEBRAS, v. 11, n. 125, p. 146-153, 2016.

BOLLEN, M. H. J. Understanding Power Quality Problems: Voltage Sags and Interruptions. IEEE Press, New York, 1999.

DECKMANN, S.; POMILIO, J. Avaliação da qualidade da energia elétrica. UNICAMP, Campinas, SP, 2017.

DUGAN, R. C.; MCGRANAGHAN, M. F.; BEATY, H.W. Electrical Power Systems Quality. McGraw Hill, ISBN:007-138622-X, 528 p. 2003.

IEEE 519-2014. Recommended Practices and Requirements for Harmonic Control in Electrical Power System. 2014.

LEITE, J. C. et al. Análise de Qualidade de Energia em Carga Comercial de Baixa Tensão Localizada no Centro da Cidade de Manaus. Revista SODEBRAS, v. 11, n. 130, p. 165-171, 2016.

MAGALHÃES, F. D.; SIMONETTI, D. S. L. A Influência das Cargas do Centro Tecnológico na Rede Elétrica da Universidade Federal do Espírito. Revista SODEBRAS, v. 12, n. 135, p. 130-134, 2017.

MARTINHO, E. Distúrbios da Energia Elétrica. São Paulo: Ed. Érica, 2009.

NASSIF, A. B.; YADANPANAHI, H.; TORQUATO, R. Harmonic Characterization of Modern Residential
Distributed Energy Resources, 2018 IEEE Canadian Conference on Electrical \& Computer Engineering (CCECE), Quebec, QC, Canada, pp. 1-4, 2018.

OLIVEIRA, E. F. Avaliação da Distorção Harmônica Total de Tensão no Ponto de Acoplamento Comum Industrial Usando o Processo KDD Baseado em Medição. 2018. 150f. Tese (Doutorado em Engenharia Elétrica) Universidade Federal do Pará (UFPA), Belém, PA, 2018.

PINTO, A. F. C. Avaliação dos impactos de sistemas fotovoltaicos conectados à rede de distribuição de baixa tensão. 2016. 108f. Tese (Doutorado em Engenharia Elétrica) - Pós-Graduação em Energia - Universidade de São Paulo (USP), São Paulo, SP, 2016.

RAMOS, M. C. G.; RAMOS, M. C. E. S. A Contribution to the Health Area by means Assessment of the Impact of Quality Power and of Electrical Installations upon Electromedical Equipment. Science Journal of Electrical and Electronic Engineering, v. 2013, p. 1-17, 2013.

RAMOS, M. C. G.; TAHAN, C. M. V. An Assessment of the Electric Power Quality and Electrical Installation Impacts on Medical Electrical Equipment Operations at Health Care Facilities. American Journal of Applied Sciences, v. 6, p. 638-645, 2009.

SANKARAN, C. Power quality. Boca Raton: CRC Press, 2002.

SOUZA, E. O. et al. Avaliação Técnica dos Cenários Harmônicos em Cargas Residenciais. Revista SODEBRAS, v. 12, n. 135, p. 135-140, 2017.

\section{COPYRIGHT}

Direitos autorais: Os autores são os únicos responsáveis pelo material incluído no artigo.

Submetido em: 14/01/2019 Aprovado em: 03/02/2019 


\title{
Revista SODEBRAS - Volume 14 \\ $\mathrm{N}^{\circ} 158$ - FEVEREIRO/ 2019
}

\section{ANÁLISE NUMÉRICA DA INFLUÊNCIA DA VELOCIDADE DE SOLDA EM VASOS DE PRESSÃO CILÍNDRICOS}

\section{NUMERICAL ANALYSIS OF THE INFLUENCE OF WELDING SPEED IN CYLINDRICAL PRESSURE VESSELS}

\author{
FERNANDA FIGUEREDO SANTOS ${ }^{1}$; JAYANN ISMAR LIRA ALMEIDA² \\ 1; 2 - UNIVERSIDADE FEDERAL DA BAHIA \\ ffernaand@gmail.com, jayann.almeida@ufba.br
}

\begin{abstract}
Resumo - Este trabalho tem como objetivo a determinação das tensões residuais de vasos de pressão cilíndricos submetidos a reparos por solda via análise numérica. No reparo por soldagem, a luva é anexada ao vaso de pressão através de duas soldas longitudinais e duas circunferenciais. Foi realizada a modelagem do vaso de pressão, do reparo e das soldas de acordo com a norma. Os parâmetros do cordão de solda serão adotados com base o que acontece na prática, e com isso serão feitas as análises das tensões residuais variando a velocidade do cordão de solda. A partir disso,

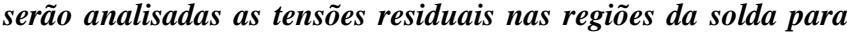
verificar o comportamento dos resultados após o período de resfriamento pelo Método dos Elementos Finitos.
\end{abstract}

Palavras-chave: Método dos Elementos Finitos. Vaso de Pressão. Soldagem.

Abstract - This work has how objective the determination cylindrical pressure vessel tests with a weld repair through numerical analysis. In welding repair, a glove is attached to the pressure vessel through two longitudinal welds and two circumferential welds. Was performe modeling of the pressure, the repair and the welds acoording to the standart. The parameters of the weld bead will be adopted on the basis of what happens in practice, and this will be done the analyzes of the residual stresses varying the speed of the weld bead. From this, will be analyzes the residual stresses in the regionsof the weld to verify the behavior of the results after the cooling period by the Finite Element Method.

Keywords: Finite Element Method. Pressure Vessel. Welding.

\section{INTRODUÇÃO}

Os vasos de pressão são equipamentos presentes e importantes em muitas indústrias químicas e petroquímicas, usinas de açúcar e etanol, farmacêuticas dentre outras, também são bastantes utilizados para os processos industriais que envolvam fluidos ou gases, que operam com pressões internas diferente da pressão atmosférica. Ou conforme a NR13 de 2014, vasos de pressão são equipamentos que contêm fluidos sob pressão interna ou externa, diferente da atmosférica.

Os vasos de pressão, em sua grande maioria, são fabricados a partir da união de chapas de aço utilizando o processo de soldagem. Porém, esse processo provoca distorções no material base. Distorções estas que podem levar o equipamento a falhar. Por conta disto é importante tomar a máxima cautela durante o processo de escolha dos parâmetros do cordão de solda, assim como devem ser seguidos os procedimentos estabelecidos nas normas para seu reparo ou fabricação, pois desta maneira são garantidas as etapas necessárias para manter a integridade estrutural do vaso de pressão e não provocar danos ao meio envolvido.

Os engenheiros realizam estudos sobre a avaliação da integridade estrutural em diversas situações, como reparar, projetar ou até mesmo avaliar se o equipamento está de acordo com as normas e é amplamente utilizada em paradas para manutenção para avaliar se os equipamentos podem ou não continuar em operação. Essas avaliações podem ser realizadas por diversos Softwares, como: ANSYS, COSMOS/M, NASTRAN, ABAQUS, entre outros, que utilizam análise numérica com base no método dos elementos finitos (MEF).

O presente trabalho tem por objetivo obter resultados, via método dos elementos finitos, como tensões residuais e fluxo de calor total, por meio da realização de análises transiente térmica e estrutural para a determinação das tensões residuais no vaso de pressão ocasionadas pela variação da velocidade de soldagem no vaso de pressão.

\section{MÉTODO}

O vaso de pressão em questão é utilizado em uma indústria petroquímica, que apresenta perda de espessura causada pela corrosão, utilizado como filtro de carvão ativado conforme mostrado na Figura (1). Por questão de exigência técnica de projeto e construção, esse vaso é constituído de aço ASTM A516 Grau 70 (aço inoxidável austenítico do tipo não sensitizável de baixo teor de carbono). Esse material é muito utilizado para construção de vasos de pressão, pois possui boa capacidade de absorver energia quando uma falha está presente e alta resistência a corrosão.

Figura 1 - Fotografia do filtro de carvão ativado estudado

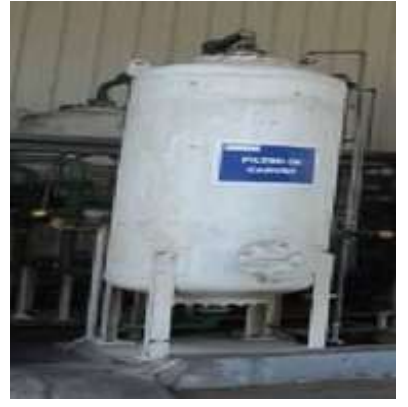

Fonte: Autores, 2017. 
As seguintes características de trabalho do vaso de pressão são: pressão de trabalho de 2,07 $\mathrm{MPa}$; temperatura de trabalho de $177 \mathrm{oC}$; diâmetro interno de 1,22 m; espessura: 19,05 mm; tensão admissível de 137,70 MPa.

O passo a passo do modelo geométrico do conjunto do vaso de pressão-reparo-solda está descrito em (Almeida, 2017). A Figura (2) mostra o resultado da modelagem.

Figura 2 - Modelagem completa do conjunto vaso de pressão-

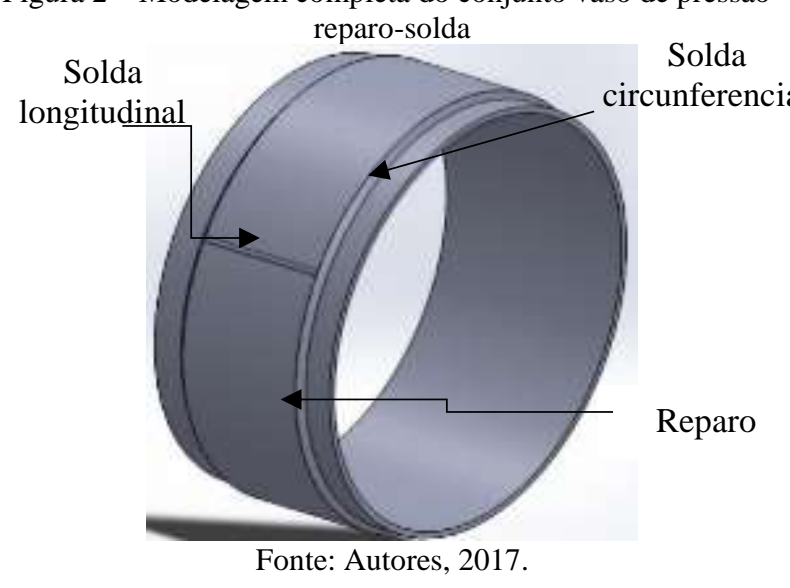

Na Figura (3) é apresentado as propriedades mecânicas do conjunto vaso de pressão.

Figura 3 - Propriedades Mecânica para o aço ASTM A516 Grau 70

\begin{tabular}{|c|c|c|}
\hline ASTM A516 Gr. 70 & \multicolumn{2}{|c|}{ Propriedades } \\
\hline Densidade $\left(\mathrm{Kg} / \mathrm{m}^{3}\right)$ & \multicolumn{2}{|c|}{7960} \\
\hline $\begin{array}{l}\text { Condutividade térmica } \\
\text { (W/m.K) }\end{array}$ & \multicolumn{2}{|c|}{58} \\
\hline Calor específico (J/kg.K) & \multicolumn{2}{|c|}{521} \\
\hline \multirow{5}{*}{$\begin{array}{l}\text { Coeficiente de expansão } \\
\text { térmica }\left(1 /{ }^{\circ} \mathrm{C}\right)\end{array}$} & $100^{\circ} \mathrm{C}$ & $1,31 \mathrm{e}-6$ \\
\hline & $200^{\circ} \mathrm{C}$ & $1,37 \mathrm{e}-6$ \\
\hline & $300^{\circ} \mathrm{C}$ & $1,41 \mathrm{e}-6$ \\
\hline & $400^{\circ} \mathrm{C}$ & $1,43 \mathrm{e}-6$ \\
\hline & $450^{\circ}$ & $1,44 \mathrm{e}-6$ \\
\hline \multirow{4}{*}{$\begin{array}{l}\text { Módulo de Young }\left(10^{3}\right. \\
\text { MPa) }\end{array}$} & $20^{\circ} \mathrm{C}$ & 206,8 \\
\hline & $300^{\circ} \mathrm{C}$ & 201,3 \\
\hline & $400^{\circ} \mathrm{C}$ & 196,7 \\
\hline & $450^{\circ} \mathrm{C}$ & 194,3 \\
\hline \multirow{4}{*}{$\begin{array}{c}\text { Limite de } \\
\text { escoamento(MPa) }\end{array}$} & $20^{\circ} \mathrm{C}$ & 262 \\
\hline & $300^{\circ} \mathrm{C}$ & 234 \\
\hline & $400^{\circ} \mathrm{C}$ & 230 \\
\hline & $450^{\circ} \mathrm{C}$ & 226 \\
\hline Módulo tangente (MPa) & \multicolumn{2}{|c|}{431,4} \\
\hline $\begin{array}{l}\text { Resistência última a tração } \\
(\mathrm{MPa})\end{array}$ & \multicolumn{2}{|c|}{482,6} \\
\hline Coeficiente de Poisson & \multicolumn{2}{|c|}{0,303} \\
\hline
\end{tabular}

Fonte: Almeida, 2017.

O modelo de plasticidade adotada foi a elastoplástica com encruamento linear e a temperatura de fusão do material é de $1873^{\circ} \mathrm{C}$. O diagrama de tensão do material x deformação pode ser encontrado em Almeida, 2017.

\section{1 - Geração da malha}

No caso deste trabalho, será utilizado como parâmetro de entrada $7 \mathrm{~mm}$ como tamanho do elemento para geração da malha. Esse valor foi selecionado adotando de forma aleatório, porem de modo esse valor fosse inferior a menor distância existente no conjunto vaso de pressão, que nesse caso é $15,70 \mathrm{~mm}$, correspondente à superfície superior da solda longitudinal, como mostra a Figura (4), para que possuam resultados das análises nessa região.

Um menor valor do tamanho de elemento mencionada acima poderia gerar problemas durante a convergência dos resultados, além de gerar uma quantidade maior de dados para serem processados, exigindo melhores computadores para o processamento.

Para convergia dos resultados foi

Figura 4 - Largura do cordão de solda longitudinal

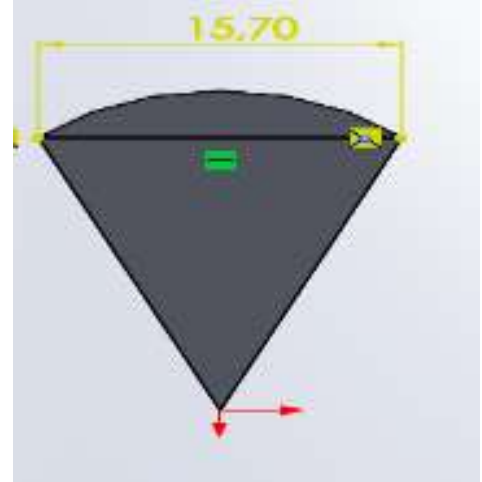

Fonte: Autores, 2018.

Com base nesses dados, foram gerados no total 46898 elementos e 124206 nós. A malha ainda foi composta por elementos tetraédricos de 10 nós e elementos hexaédricos de 20 nós. Essa escolha de composição é realizada pelo próprio programa, baseado na complexidade da geometria.

\section{2 - Condições de Contorno para as Análises em Elementos Finitos}

\subsection{1 - Condições de Contorno para a Análise Transiente Térmica}

Na análise transiente térmica será utilizado a convecção e radiação do ambiente como condições de contorno para solução numérica.

A Figura (5) mostra as superfícies externas do vaso de pressão e reparo, e as superfícies externas das soldas longitudinais e circunferenciais nas quais serão impostas as condições de convecção determinadas abaixo, regida pela chamada Lei de Resfriamento de Newton dada pela Equação (1):

$Q=A \cdot h(T s-T \bowtie)$

Em que:

$\mathrm{Q}$ - Taxa de transferência de calor $\left[\mathrm{W} / \mathrm{mm}^{2}\right]$;

$\mathrm{h}$ - Coeficiente convectivo;

Ts - Temperatura da superfície $\left[{ }^{\circ} \mathrm{C}\right]$;

A - Área de transferência de calor. 
Figura 5 - Condição de contorno de convecção pelo ambiente nas superfícies

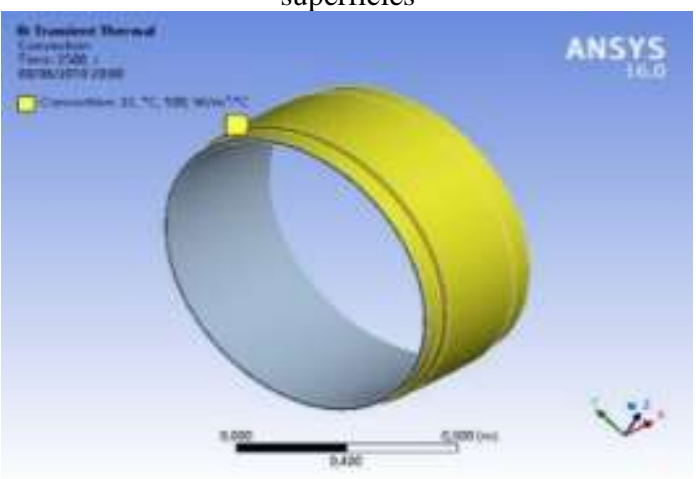

Fonte: Autores

De acordo com INCROPERA, et al., (2008):

$h=0,0005 \frac{\mathrm{W}}{\mathrm{m}^{2}}$ o $\mathrm{C}$

$\mathrm{T}_{\bowtie}=22^{\circ} \mathrm{C}$

Analogamente, a condição de contorno de radiação é aplicada nas superfícies externas do vaso de pressão e do reparo, conforme mostra a Figura (6).

Figura 6 - Condição de contorno de radiação pelo ambiente nas superfícies

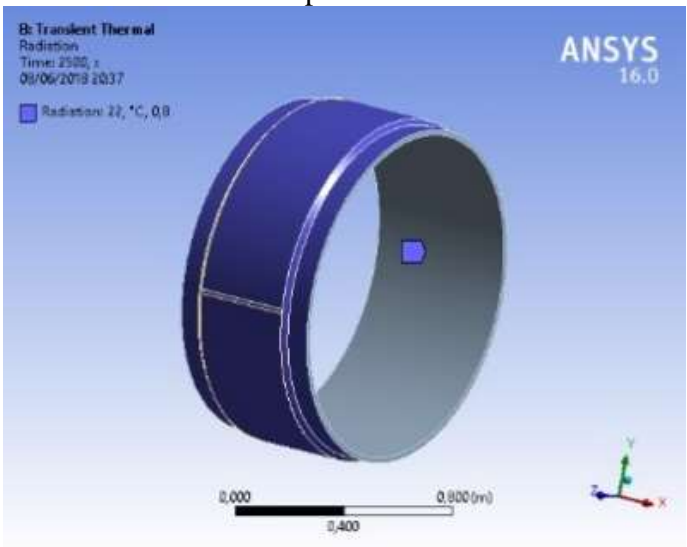

Fonte: Autores.

De acordo com INCROPERA, et al., (2008) e a chamada Lei de Stefan Boltzann dada pela Equação (2), temos:

$Q=\varepsilon \sigma\left(T s^{\wedge} 4-T v i z^{\wedge} 4\right)$

Em que:

$\varepsilon-$ Emissividade $-\varepsilon=0,8$

$\sigma-$ Constante de Stefan-Boltzmann $=5,67 \times 10-8$ $\mathrm{W} /\left(\mathrm{m}^{2} \cdot \mathrm{K}^{\wedge} 4\right)$

Ts - Temperatura da superfície [oC];

Tviz - Temperatura do ambiente.

Por fim, ainda para esta análise, é necessário estabelecer alguns dados de entrada, como velocidade do cordão de solda e intensidade da fonte de calor, que serão descritas abaixo.

\subsection{2 - Velocidade do cordão de solda}

Este trabalho a largura do chanfro $\mathrm{V}$ é de $15,70 \mathrm{~mm}$ (ALMEIDA, 2017). Partindo desta informado e de acordo com FANOUS, YOUNAN, et al. (2011) foi escolhido o raio do eletrodo como $25 \mathrm{~mm}$, visto que a zona termicamente afetada atinge o reparo além do chanfro formado.
Para cada velocidade escolhida será necessário a determinação do tempo inicial e tempo final para duas soldas longitudinais e circunferenciais. Para a primeira solda longitudinal, tomando a velocidade de solda de $6 \mathrm{~mm} / \mathrm{s}$ e o comprimento da solda de $368,3 \mathrm{~mm}$, mesmo comprimento do reparo, é possível calcular utilizando a Equação (3):

$V=\frac{\Delta s}{\Delta t}=>\Delta t=\frac{368,3}{6}=>t=61,38 s$

É dado para cada termino de solda um tempo de preparação para a próxima solda de 20 s. Para primeira solda longitudinal também foi dado um intervalo de tempo de $20 \mathrm{~s}$ antes do início da soldagem. A Tabela (1) mostra o tempo para primeira solda.

Tabela 1 - Dados de entrada de tempo para a terceira carga térmica

$\begin{array}{cc}\text { Tempo inicial da solda } & 182,76 \text { segundos } \\ \text { Tempo final da solda } & 841,08 \text { segundos }\end{array}$

Analogamente é feito o mesmo para segunda solda circunferencial, sempre utilizando o tempo de preparação da solda e o mesmo sentindo de soldagem da primeira solda circunferencial. A Tab. (2) mostra os tempos para a segunda solda circunferencial:

Tabela 2 - Dados de entrada de tempo para a quarta carga térmica

\begin{tabular}{cc}
\multicolumn{2}{c}{ térmica } \\
\hline Tempo inicial da solda & 861,08 segundos \\
Tempo final da solda & 1519,4 segundos \\
\hline
\end{tabular}

É considerado ao fim do processo de soldagem do vaso de pressão-reparo um tempo de resfriamento, portanto será utilizado $2200 \mathrm{~s}$ ao invés de $1519,4 \mathrm{~s}$.

Analogamente, é feito o mesmo para calcular os tempos de soldagem para velocidades de $7 \mathrm{~mm} / \mathrm{s}$ e $8 \mathrm{~mm} / \mathrm{s}$, mostrados na Tabela (3), como intuito de melhor observar o comportamento da variação da velocidade de soldagem.

Tabela 3 - Dados de entrada de tempo para carga térmica para velocidades a) $7 \mathrm{~mm} / \mathrm{s}$ e b) $8 \mathrm{~mm} / \mathrm{s}$

(a)

\begin{tabular}{|c|c|}
\hline Velocidade & \\
\hline $\begin{array}{l}\text { Tempo para solda } \\
\text { longitudinal }\end{array}$ & $\begin{array}{l}52,61 \\
\mathrm{~s}\end{array}$ \\
\hline \multicolumn{2}{|c|}{ Tempo de solda longitudinal 1} \\
\hline Inicial & $20 \mathrm{~s}$ \\
\hline Final & $72,61 \mathrm{~s}$ \\
\hline \multicolumn{2}{|c|}{ Tempo de solda longitudinal 2} \\
\hline Inicial & $92,61 \mathrm{~s}$ \\
\hline Final & $145,22 \mathrm{~s}$ \\
\hline $\begin{array}{l}\text { Tempo para solda } \\
\text { circunferencial }\end{array}$ & $658,31 \mathrm{~s}$ \\
\hline \multicolumn{2}{|c|}{ Tempo de solda circunferencial 1} \\
\hline Inicial & $165,22 \mathrm{~s}$ \\
\hline Final & $729,50 \mathrm{~s}$ \\
\hline \multicolumn{2}{|c|}{ Tempo de solda circunferencial 2} \\
\hline Inicial & $749,50 \mathrm{~s}$ \\
\hline Final & $1313,77 \mathrm{~s}$ \\
\hline $\begin{array}{l}\text { Tempo final com } \\
\text { resfriamento }\end{array}$ & $2000 \mathrm{~s}$ \\
\hline
\end{tabular}


(b)

\begin{tabular}{|c|c|}
\hline Velocidade & \\
\hline $\begin{array}{l}\text { Tempo para solda } \\
\text { longitudinal }\end{array}$ & $46,04 \mathrm{~s}$ \\
\hline \multicolumn{2}{|c|}{ Tempo de solda longitudinal 1} \\
\hline Inicial & $20 \mathrm{~s}$ \\
\hline Final & $66,04 \mathrm{~s}$ \\
\hline \multicolumn{2}{|c|}{ Tempo de solda longitudinal 2} \\
\hline Inicial & $86,04 \mathrm{~s}$ \\
\hline Final & $132,07 \mathrm{~s}$ \\
\hline $\begin{array}{l}\text { Tempo para solda } \\
\text { circunferencial }\end{array}$ & $493,73 \mathrm{~s}$ \\
\hline \multicolumn{2}{|c|}{ Tempo de solda circunferencial 1} \\
\hline Inicial & $152,07 \mathrm{~s}$ \\
\hline Final & $645,81 \mathrm{~s}$ \\
\hline \multicolumn{2}{|c|}{ Tempo de solda circunferencial 2} \\
\hline Inicial & $665,81 \mathrm{~s}$ \\
\hline Final & $1159,55 \mathrm{~s}$ \\
\hline $\begin{array}{l}\text { Tempo final com } \\
\text { resfriamento }\end{array}$ & $1800 \mathrm{~s}$ \\
\hline
\end{tabular}

Todos esses dados de tempo do cordão de solda foram inseridos em uma extensão do ANSYS 16.0, chamada Moving Heat Flux, que simula a passagem de um cordão de solda em um material.

\subsection{3 - Intensidade da fonte de solda}

$\mathrm{Na}$ última etapa, existe a carga térmica essencial necessária para intensidade da fonte de calor. Essa carga térmica depende de três fatores: corrente elétrica, tensão e eficiência da solda. Esses parâmetros foram selecionados com base em FANOUS, YOUNAN, et al., (2003), com isso, foi encontrado a intensidade de $15,3 \mathrm{~W} / \mathrm{mm} 2$. Como a velocidade adotada nesse trabalho é menor que $1 \mathrm{~m} / \mathrm{min}$, de acordo com Schwedersky et al., 2011, não é necessário o aumento da corrente de soldagem.

\section{3 - Condições de Contorno para a Análise Transiente Estrutural}

Para a análise transiente estrutural, será utilizada como condição de contorno a restrição fixa (bonded) nas duas extremidades do vaso de pressão que impede o movimento nos seis graus de liberdade como é mostrado na Figura (7).

Figura 7 - Condição de contorno de restrição fixa nas extremidades do vaso de pressão

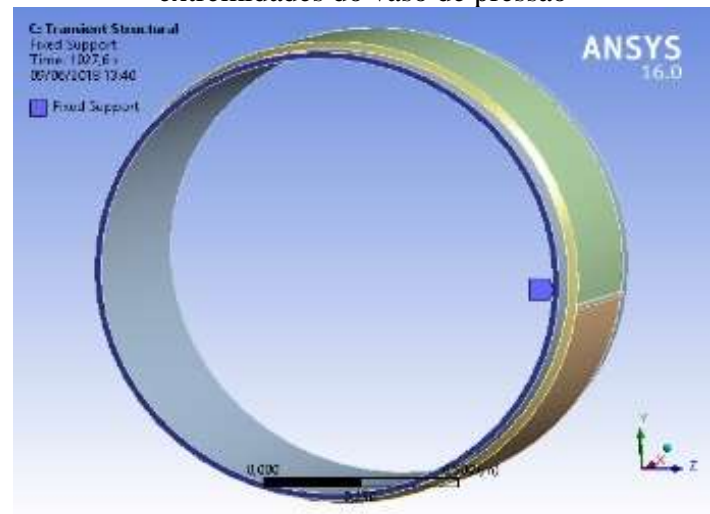

Fonte: Autores.

\section{RESULTADOS}

3.1 - Análise transiente térmica do conjunto vaso de pressão e soldagem

3.1.1 - Distribuição de temperatura no conjunto vaso de pressão

A Figura (8) apresenta a distribuição de temperatura em função do tempo durante o processo de soldagem de acordo com cada velocidade, como é mostrado na legenda do gráfico.

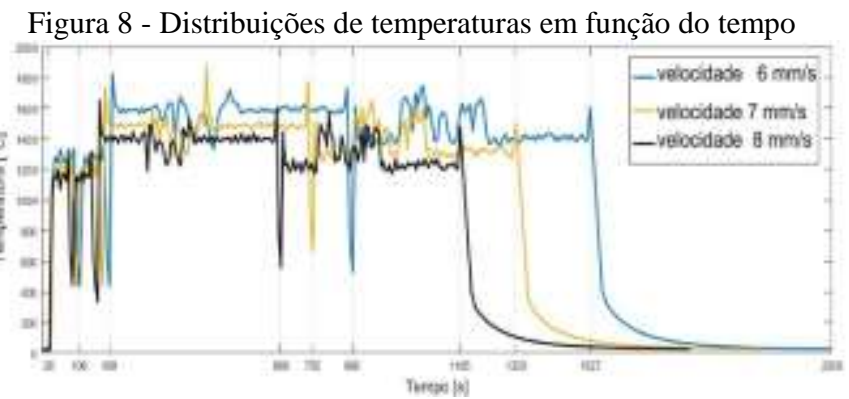

Fonte: Autores

Nota-se através do gráfico, que mesmo com a diferença de velocidade, consequentemente de tempo, existe um comportamento padrão seguido pelas três curvas representadas, com a existência da diferença de temperatura decorrente da mudança de velocidade, que diminui com o aumento da velocidade. Portanto, essa característica nos permite dividir o gráfico em cinco regiões para todas as velocidades, que podem ser descritas conforme segue abaixo: - Primeira região: compreende o intervalo de 0 a 20 segundos, que pode ser descrita como tempo de preparação para a soldagem mantendo a temperatura ambiente em torno de 22 ${ }^{\circ} \mathrm{C}$. Além do início da primeira solda longitudinal, percebese um aumento rápido de temperatura (primeiro pico de temperatura).

- Segunda região: esta região é semelhante a primeira região, caracterizada pelo início da segunda solda longitudinal, na qual existe uma diminuição de temperatura, resfriamento, referente aos 20 segundos de preparação da solda e em seguida é iniciada a segunda solda longitudinal, apresentando o segundo pico de temperatura no gráfico.

- Terceira região: esta região corresponde a primeira solda circunferencial, iniciada com a preparação da solda, correspondente a 20 segundos. No gráfico este início é representado pela segunda região de resfriamento. Em seguida é iniciado o processo da primeira solda circunferencial, em que é possível observar o terceiro pico de temperatura devido ao início do aquecimento, somado ao calor já absorvido nas soldas longitudinais realizadas. Além de apresentar uma região de tempo maior dos que as anteriores, devido ao maior caminho percorrido durante o processo de soldagem.

- Quarta região: esta região corresponde a segunda solda circunferencial, semelhante a terceira região. Iniciada com os 20 segundos de preparação da solda, sendo representado pela terceira região de resfriamento. Logo em seguida é apresentado o quarto pico de temperatura, consequência do início do processo de soldagem, apresentado características descritas na terceira região.

- Quinta região: é a região de resfriamento para todas as velocidades, caracterizada pelo decaimento de temperatura, 
apresentando uma temperatura final próxima a ambiente, 22 ${ }^{\circ} \mathrm{C}$, decorrente a convecção e radiação.

\subsection{2 - Distribuição do fluxo de calor total no conjunto vaso de pressão}

A Figura (9) apresenta os dados da distribuição de fluxo de calor total resultante da análise transiente térmica, conforme cada velocidade.

Figura 9 - Distribuições de fluxo de calor total em função do tempo

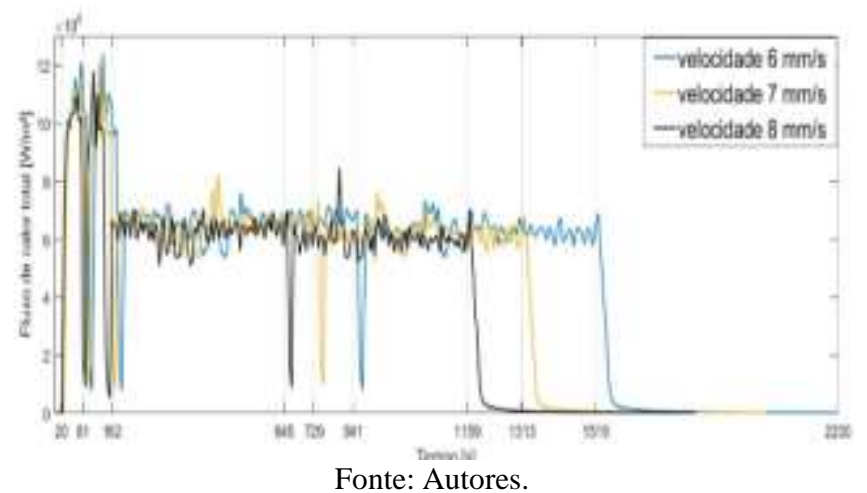

Comparando a Figura (8) ao gráfico anterior da distribuição da temperatura no conjunto do vaso de pressão, é possível notar um comportamento semelhante decorrente da proporcionalidade existente entre fluxo de calor e temperatura. Por conta dessa mesma proporcionalidade, pode ser explicado em relações as curvas do gráfico, o aumento do fluxo de calor com a diminuição da velocidade.

Dado pela Equação (4), o fluxo de calor através de uma superfície é fornecido pela relação entre a quantidade de calor Q que atravessa a superfície e o intervalo de tempo decorrido.

$\Phi=\frac{Q}{\Delta t}$

$\mathrm{O}$ valor de $\mathrm{Q}$ pode ser calculado pelas equações abaixo, ressaltando que a predominância para a soldagem é do fluxo de calor são convecção e condução, respectivamente.

$Q=h\left(T_{s}-T_{\bowtie}\right)$

$Q=-k\left(\frac{d T}{d x}\right)$

Observando a região de fluxo de calor total com maiores picos, Figura (9), encontra-se, para todas a velocidades, as regiões das soldas longitudinais diferentemente do que pode ser observado na distribuição da temperatura, pois existe uma mudança de geometria e chanfro na solda, que afeta o coeficiente de convecção, já que o mesmo é influenciado geometria, regime do escoamento e o tipo de fluido.

\section{2 - Análise transiente estrutural do conjunto vaso de pressão}

3.2.1 - Distribuição das tensões de von Mises no conjunto vaso de pressão

A Figura (10a), Figura (10b) e Fig (10c) mostra as tensões von Mises na estrutura para velocidades $6 \mathrm{~mm} / \mathrm{s}, 7$ $\mathrm{mm} / \mathrm{s}$ e $8 \mathrm{~mm} / \mathrm{s}$, respectivamente.
Figura 10a - Distribuição das tensões de von Mises na estrutura para velocidade $6 \mathrm{~mm} / \mathrm{s}$

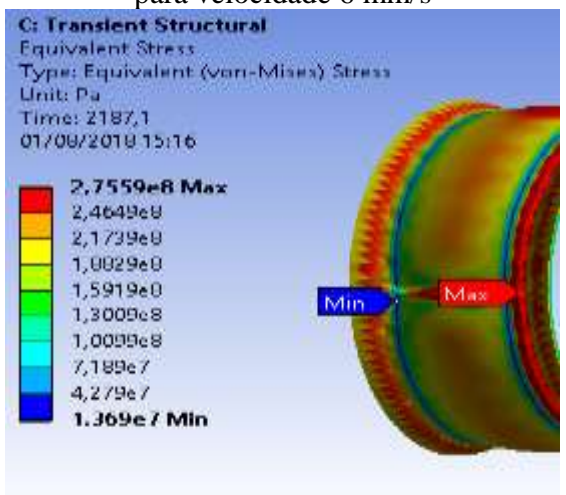

Fonte: Autores.

Figura 10b - Distribuição das tensões de von Mises na estrutura para velocidade $7 \mathrm{~mm} / \mathrm{s}$

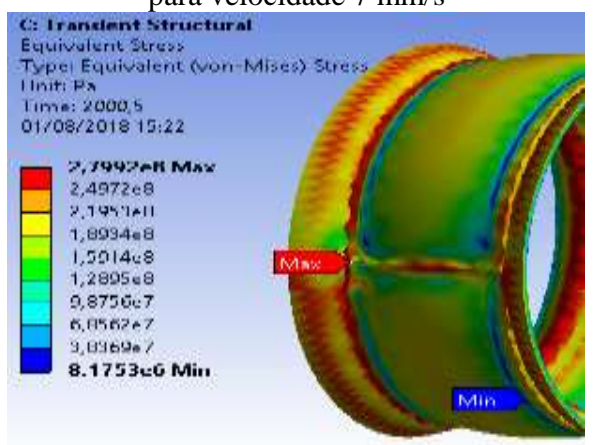

Fonte: Autores.

Figura 10c - Distribuição das tensões de von Mises na estrutura

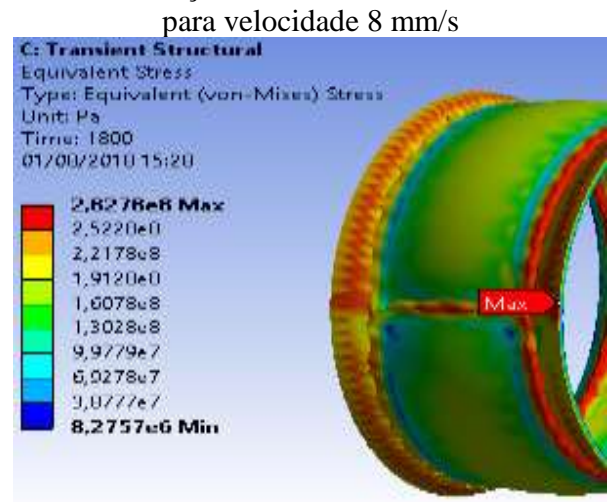

Fonte: Autores.

É possível concluir através das Figura (10a), (10b) e (10c) que as maiores tensões de von Mises observadas ocorrem na região central e nas proximidades das soldas longitudinais e circunferenciais, observadas pelas regiões na cor vermelha. Comparando as três figuras verifica-se também que existe um aumento da tensão de von Mises acompanhada do aumento de velocidade.

Ainda analisando as imagens térmicas anteriores, Figura (10a), (10b) e (10c), com a Figura (11) é possível afirmar ainda, pela formação da região na cor vermelha, que a área mais crítica observada em relação as soldas longitudinais, é a primeira solda longitudinal para todas as velocidades, causadas também pela soma dos efeitos térmicos causado pelas soldas posteriores e tempo de resfriamento. 
Figura 11 - Distribuição das tensões de von Mises na estrutura para soldas longitudinais

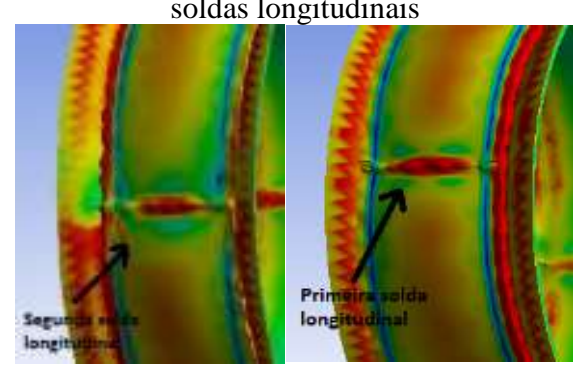

Fonte: Autores.

Conforme a Figura (12) é possível observar na distribuição das tensões von Mises que quando o valor da velocidade aumenta tende a aumentar os picos das tensões von Mises, devido ao menor tempo de resfriamento existente entre os passes das soldas circunferenciais e longitudinais. Ainda é possível notar maiores picos de tensões situadas nas proximidades do encontro entre a primeira solda circunferencial e a primeira solda longitudinal, para todas as velocidades estabelecidas para soldagem, situadas nas regiões entre 162 segundos e 841 segundos.

Figura 12 - Distribuição das tensões von Mises no conjunto vaso de pressão

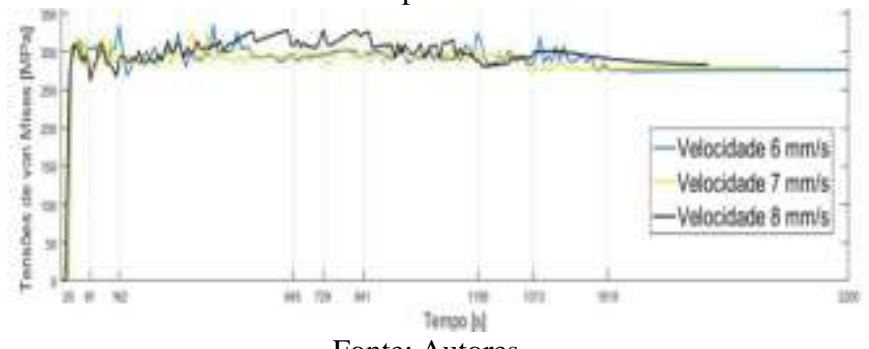

Fonte: Autores.

3.2.2 - Distribuição das tensões de von Mises no conjunto vaso de pressão

Na Figura (13) é possível notar uma proporcionalidade em relação a Figura (8). Na distribuição da deformação plástica é possível notar que as duas primeiras regiões bem definidas, referentes as duas soldas longitudinais, se apresentam em um menor período do gráfico comparando com as demais áreas e possui menores valores decorrente do menor percurso soldado. A região seguinte é apresentada por ter valores bem maiores decorrente do maior percurso, consequente maior tempo e maiores deformações plásticas serão obtidas durante o processo de soldagem.

Figura 14 - Distribuição da Deformação Plástica no conjunto vaso de pressão

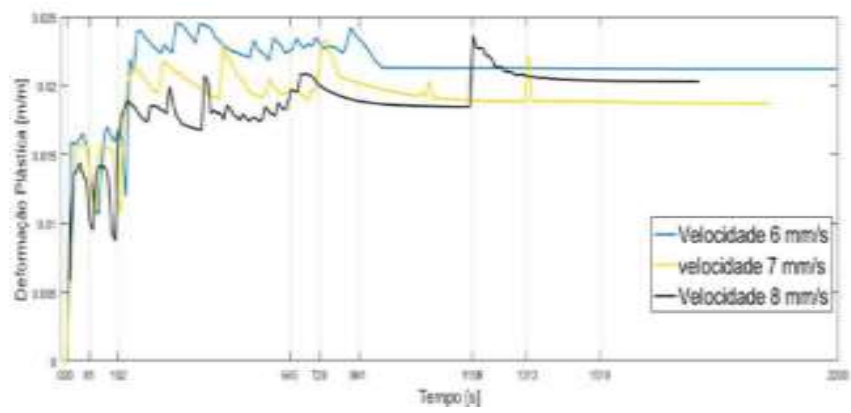

Fonte: Autores.

Em relação a cada curva é perceptível a diminuição da deformação plástica com o aumento da velocidade, causado pela diminuição do tempo de acordo com a velocidade e assim diminuição da energia do processo de soldagem em cada ponto.

\section{CONCLUSÃO}

Conforme os resultados obtidos através do método abordado, pode-se verificar que apesar da pequena variação, apenas $1 \mathrm{~mm} / \mathrm{s}$ da velocidade de soldagem, obteve-se resultados significativos nos campos das tensões von Mises, temperatura, fluxo de calor total e deformações plásticas, além de possibilitar a discussão do comportamento e causas dos resultados obtidos para cada velocidade de soldagem, nos quais devem ser considerados uma série de fatores, como geometria e tempo. Proporcionando também resultados que possibilitam o estudo com outros parâmetros de soldagem para se obter o ponto ideal do processo.

\section{REFERÊNCIAS}

ALMEIDA, J.I.L.. Determinação das tensões residuais via análise numérica transiente térmica de vasos de pressão submetidos a reparos por soldagem, Tese - Universidade Federal da Paraíba, 2017.

BAKER, A.J.. Finite Elements: Computational Engineering Sciences. 1o Edition, John Wiley \& Sons, Ltd, USA, 2012.

CHANDRUPATLA, T.R., BELEGUNDU, A.D. Elementos finitos, editora Person, $4^{\mathrm{a}}$ ed., 2014.

HARVEY, J.F.. Theory and Design of Modern Pressure Vessels. Van Nostrand Reinhold Co, New York, 1974.

INCROPERA, et al.. Fundamentos de transferência de calor e de massa. $6^{\text {a }}$ Edição LTC, Rio de Janeiro.

LANCASTER, J.F.. Metallurgy of Welding. 6a Edição, Woodhead, Cambridge, 2007.

PAIVA, V.E.L.. Simulação de tensões residuais de soldagem e seu alívio por teste hidrostático. Dissertação de metrado, PUC-Rio, 2015.

SAVAGE, W. F.; NIPPES, E. F.; AGUSA, K.. Effect of Arc Force on Defect Formation in GTA Welding. Welding Journal, jul. 1979. 212s-224s.

SCHWEDERSKY, M.B., DUTRA, J.C., OKUYAMA, M.P., SILVA, R.H.G.. High Productivity TIG Welding: Influence of Shielding Gases on the Limit Speed for Defect Formation, Santa Catarina, Brasil, 2011.

\section{COPYRIGHT}

Direitos autorais: Os autores são os únicos responsáveis pelo material incluído no artigo.

Submetido em: 10/12/2018 Aprovado em: 19/02/2019 


\author{
Revista SODEBRAS - Volume 14 \\ $\mathrm{N}^{\circ} 158$ - FEVEREIRO/ 2018
}

\title{
PAPER SUBSTRATES TENSILE TESTING USING GRAPHITE PIEZORESISTORS FOR EXTRACTION OF THE EXPERIMENTAL YOUNG MODULE
}

\section{ENSAIO DE TRAÇÃO EM SUBSTRATOS DE PAPEL USANDO PIEZORESISTORES DE GRAFITE PARA EXTRAÇÃO DO MÓDULO DE YOUNG EXPERIMENTAL}

\author{
DÉBORA ALINE KOTZ1; CARLOS EDUARDO ANDRADES²; CRISTIANE SONEGO ROLIM³; LUIZ \\ ANTONIO RASIA ${ }^{4}$; ANTONIO CARLOS VALDIERO ${ }^{5}$ \\ $1 ; 2 ; 3 ; 4 ; 5$ - DCEENG - DEPARTMENT OF EXACT SCIENCES AND ENGINEERING - UNIJUI - \\ REGIONAL UNIVERSITY OF THE NORTHWEST OF THE STATE OF RIO GRANDE DO SUL - \\ PANAMBI CAMPUS \\ deborakotz@gmail.com; carloseduardoandrades@gmail.com; crisonego@hotmail.com; rasia@unijui.edu.br; \\ valdiero@unijui.edu.br
}

\begin{abstract}
This work shows the design and assembly of a machine for tensile testing of polymers, especially industrialized paper type A4 used for deposition of fine graphite films obtained from pencils. The mechanical stresses, deformations and the modulus of elasticity of the fabricated specimen are analyzed. These mechanical parameters are important for the development of strain gauge force sensing devices.
\end{abstract}

Keywords: Young's Module. Polymer. Piezoresistive Sensors.

Resumo - Este trabalho mostra o projeto e montagem de uma máquina para testes de tração de polímeros, em especial, papel industrializado tipo A4 utilizado para deposição de filmes finos de grafite obtidos de lápis. São analisadas as tensões mecânicas, deformações $e$ o módulo de elasticidade dos corpos de provas fabricados. Estes parâmetros mecânicos são importantes para o desenvolvimento de dispositivos sensores de força tipo strain gauge.

Keywords: Módulo de Yong. Polímero. Sensores Piezoresistivos.

\section{INTRODUCTION}

This paper proposes an experimental technique to identify and characterize the elasticity modulus of A4 paper to be used as a substrate for the deposition of piezoresistive graphite films according to ISO19242:2008, which considers a constant velocity for the elongation of the fibers of cellulose (PEDRALI, RASIA and VALDIERO, 2017).

The literature (SILVA et al., 2016) shows that the high cost and complex manufacturing process of sensors by conventional methods has limited the applications and commercialization of flexible devices. For this purpose, a tensile and mechanical compression testing machine was assembly as shown in Figure 1.
Figure 1 - Design and Photograph of the Traction and Mounted Compression Machine
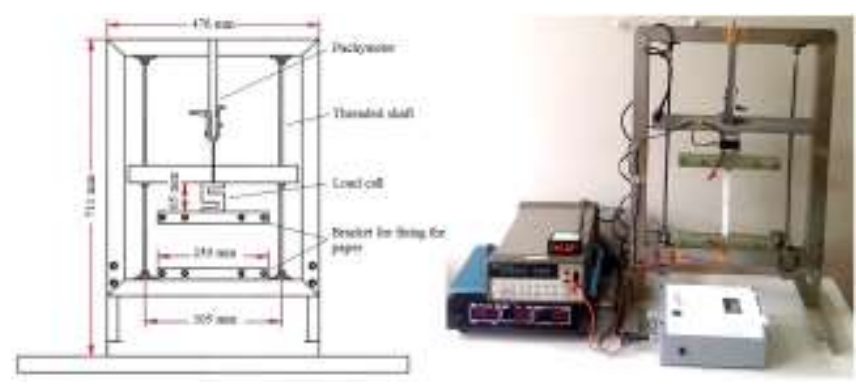

Source: Prepared by the authors, 2018.

The traction machine has been constructed entirely of stainless steel, has four bearings where two threaded bars are fixed by where the moving claw moves. He fixed claw is at the bottom of the machine. Both claws have four clamping screws for better clamping of the test piece.

The traction and compression movement is performed through two DC motors with the aid of reduction boxes of $0.6 \mathrm{rpm}$. The elastic deformation is measured by an analog pachymeter with an accuracy of $0.05 \mathrm{~mm}$. The mass exerted is measured through a load cell with a capacity of $20 \mathrm{~kg}$ coupled on a conventional digital scale.

The machine has a potentiometer that regulates the speed of traction and compression from 0 to $100 \%$ of its rotation. In order to carry out the tensile tests it is possible to make use of the so-called test specimens which are specially designed and dimensioned for the test and comply with specific standards.

Cellulose is a natural polymer in greater abundance in nature and its derivatives have been used in the most varied industrial segments. Their fibers can be functionalized so that their properties such as 
permeability and reactivity can be adapted as needed. The sheet of paper is typically composed of micro fibrils with diameters of several nanometers to one micron and lengths up to $40 \mathrm{~mm}$ having cellulose the crystal structure as suggested by $\mathrm{X}$-ray diffraction analysis, that shows diffraction peaks at $15.6^{\circ}$, and $23^{\circ}$ corresponding to the (110), and (200) planes, as shown in Fig. 2.

Figure 2 - X-ray diffraction peaks of cellulose

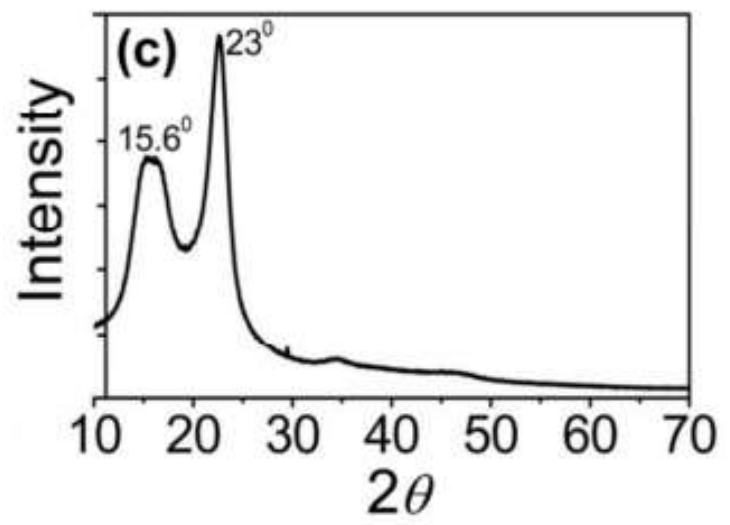

Source: Mahadeva, Walus, and Stoeber, (2015).

The crystallographic planes are important for the deposition of graphite films by the GoP - Graphite on Paper process and determination of the sensitivity factors of the piezoresistors (GABBI et al., 2017).

Figure 3 shows an optical microscopic analysis of the graphite films deposited on the paper substrate with grammage $75 \mathrm{~g} / \mathrm{m}^{2}$. In this analysis it is possible to observe the substrate fibers and graphite grain accumulation regions (PEDRALI et al., 2018) that are important for understanding the conduction mechanisms in the material.

Figure 3 - Microscopy of graphite film on paper

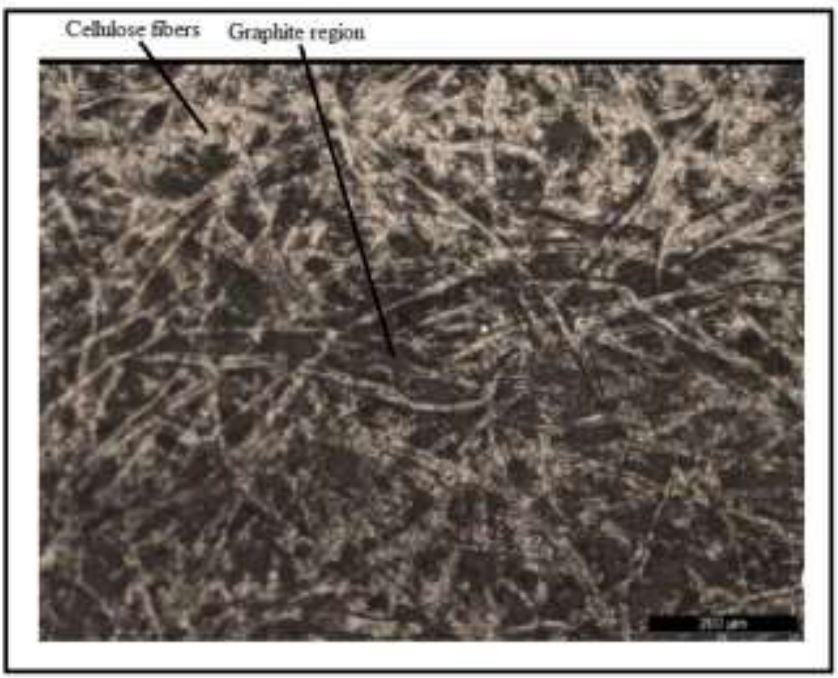

Source: Adapted from PEDRALI, P., C., et al., (2018).

The conductivity and other physical characteristics of the graphite are due to the arrangement of atoms in the material, forming sheet-like structures attracted by weak bonds (RASIA, PEDRALI, VALDIERO, 2018).

Figure 4 shows the microfibers of the cellulose indicating that it has ordered crystalline regions and disordered amorphous regions, which allows to choose the best position for deposition of piezoresistive films on the surface of the paper.

Figure 4 - Structure of the cellulose and surface for deposition of graphite films

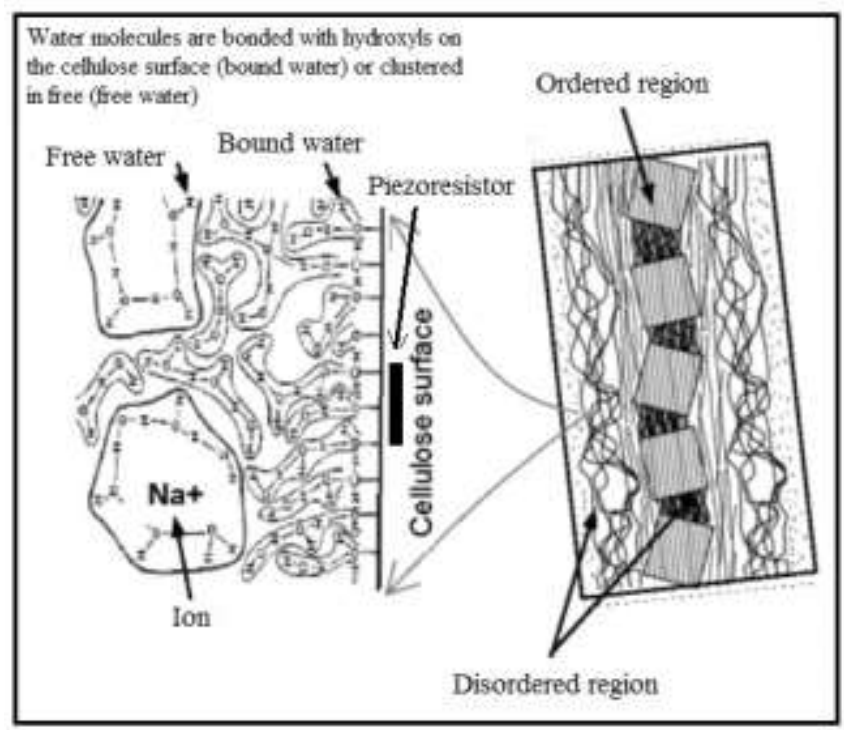

Source: Adapted from Kim, Yun and Ounaies, (2006).

In nature, cellulose never occurs as a single chain, but exists from the moment of its synthesis as a crystalline arrangement of many microfibrils of parallel and oriented chains, which are fundamental structural units. A cellulose micro fibril has amorphous and crystalline domains (KIM, YUN and OUNAIES, 2006).

In recent years a wide range of devices and sensors based on paper and piezoresistive graphite films has been developed, including strain gauges, super capacitors, energy storage, pressure sensors among others (SILVA et al., 2016).

\section{METHODS}

To determine the mechanical tensile strength of the paper and the maximum stress supported by the fiber, the pattern shown in Figure 5 is followed. The elongation rate of the cellulose fibers is considered constant.

In this work ten paper test bodies were prepared and subjected to tensile tests up to the tensile stress limit.

Figure 5 - Illustration of the paper test body

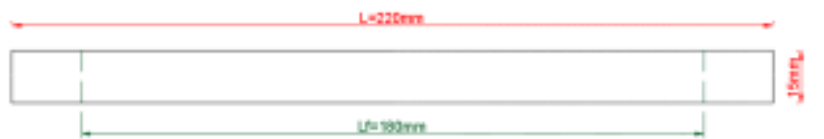

Source: Prepared by the authors, 2018.

The specimen must have a width of $15 \mathrm{~mm}$ and a sufficient length to be attached to the staples. The effective length of the proof body $\left(\mathrm{L}_{\mathrm{f}}\right)$, i.e. the distance between the fastening lines is $180 \mathrm{~mm}$.

The mechanical and geometric properties were analyzed for the initial length $\left(\mathrm{L}_{\mathrm{i}}\right)$, final length $\left(\mathrm{L}_{\mathrm{f}}\right)$, length variation $(\Delta \mathrm{L})$, elastic deformation $(\varepsilon)$, applied mechanical stress $(\mathrm{T})$, to determine the Elasticity Modulus (E) of the paper according to the equations: 
$\Delta L=L_{f}-L_{i}$

$\varepsilon=\frac{\Delta L}{L_{i}}$

$E=\frac{T}{\varepsilon}$

The modulus of elasticity characterizes how much a material resists elastic deformation, that is, it is the measure of its mechanical stiffness being associated with the determination several other properties of the analyzed material.

Figure 6 shows that ruptures occurred at the bottom of the specimen crimping, in most tests performed.

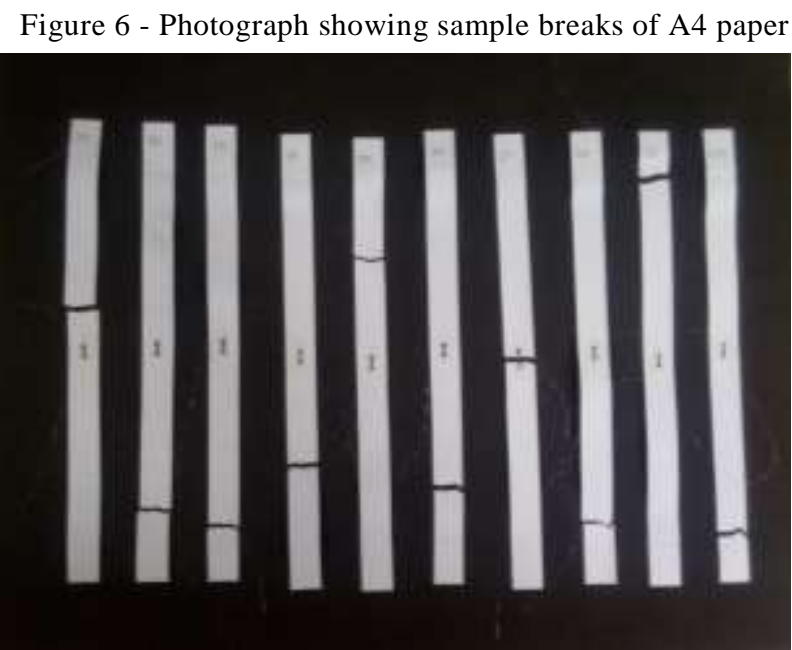

Source: Prepared by the authors, 2018.

\section{RESULTS AND DISCUSIONS}

Figure 7 shows the values for the modulus of elasticity obtained using the prototype machine of Figure 1.

Figure 7 - Young's modulus and indicative of the rupture stress of the samples

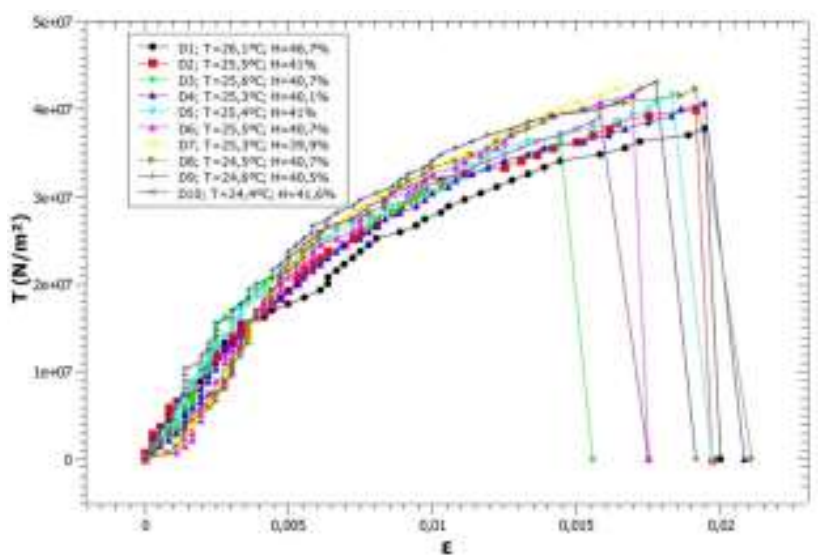

Source: Prepared by the authors, 2018.

It is observed in Figure 7 that the minimum and maximum temperatures during the tests ranged from 24.4 ${ }^{\circ} \mathrm{C}$ to $26.1^{\circ} \mathrm{C}$ and the test environment humidity was between $39.9 \%$ and $46.7 \%$.
The analysis of the results showed that the sample D3 had the least elastic deformation $\varepsilon=0.015556$, breaking with a mechanical stress of $\mathrm{T}=3.63 \mathrm{X} 107 \mathrm{~N} /$ $\mathrm{m}^{2}$. Samples D7 and D9 broke with a mechanical stress $\mathrm{T}=4.3 \mathrm{X} 107 \mathrm{~N} / \mathrm{m}^{2}$ while sample $\mathrm{D} 8$ had the highest elastic strain $\varepsilon=0.021111$. The average mechanical tensile stress of the samples was $4.06 \times 107 \mathrm{~N} / \mathrm{m}^{2}$ equivalent to a mass of $5.46 \mathrm{~kg}$.

In this analysis the average mechanical deformation of breakage was 0.019028 and the mean Young's Modulus found was $2.13 \times 109 \mathrm{~N} / \mathrm{m}^{2}$.

\section{CONCLUSION}

The experimental value of the Young's Module for paper, obtained in this paper, is close to the value available in the literature. However, this is critical for the design of piezoresistive graphite sensing elements and their production in large quantities. The value obtained was found under laboratory temperature and humidity conditions this is important when designing sensor devices using flexible polymeric paper substrates.

\section{REFERENCES}

ISO1924-2 Third edition 2008-12-15. Disponível em <https://www.sis.se/api/document/preview/910681/>Aces so em 18 de novembro de 2018.

GABBI, R., SILVA, G., G., W., M. SCARTON, L., HAMMES, G., RASIA, L., A., VALDIERO, C., A. Modelagem Matematica de Elementos Sensores Usando Grafite. Proceeding Series of the Brazilian Society of Applied and Computational Mathematics, vol. 5, n. 1, 2017.

KIM, J., YUN, S., Ounaies, Z. Discovery of Cellulose as a Smart Material Macromolecules, v. 39, p. 4202-4206, 2006.

MAHADEVA, S. K., WALUS, K., STOEBER, B. Paper as a Platform for Sensing Applications and Other Devices: A Review. ACS Appl. Mater. Interfaces, p. 1 $-65,2015$.

PEDRALI, P., C., VAlDiERO, A., C., RASiA L., A., KINALSKI, N., M. Estudo das Propriedades Mecânicas do Papel como Substrato para Elementos Sensores Piezoresistivos. X Simposio Internacional de Ingeniería Industrial: Actualidad y Nuevas Tendencias, 2017. Universidad Nacional de Misiones, Facultad de Ingeniería, Departamento de Ingeniería Industrial. Oberá, Argentina. p. 1070 - 1078. ISSN: 1856-8343.

PEDRALI, P., C., RASIA, L., A., VALDIERO, A., C., FRAGA, M., A. Graphite Piezoresistive Sensors in Polymeric Substrates. International Journal of Advanced Engineering Research and Science. doi.10.22161/ijaers.5.10.14, p. 105 -109, 2018.

RASiA, L., A., PEDrAli, P., C., VAldiero, A., C. Characterization of Piezoresistive Sensors of Graphite on Paper Substrate. Proceedings of the LACCEI International Multi-conference for Engineering, Education and Technology, v. 1, p. 1-6, 2018. ISSN: 2414-6390. 
SILVA, G., G., W. M., SCARON, L., GABBI, R., DUTRA, A. M. R., RASIA, L., A., VALDIERO, A. Modelagem, Caracterização e Análise dos Fatores de Sensibilidade de Elementos Piezoresistivos de Grafite.

Revista SODEBRAS, v. 11, p. 112 - 115, n. 128, 2016.

\section{COPYRIGHT}

Authors are solely responsible for the material included in the article.

Submetido em: 19/12/2018

Aprovado em: 29/01/2019 